\title{
A comunicação científica em saúde: uma abordagem semiótica
}

Maria do Carmo Avamilano Alvarez

Tese apresentada ao Programa de PósGraduação em Saúde Pública da Faculdade de Saúde Pública da Universidade de São Paulo para obtenção do título de Doutor em Ciências.

Área de concentração: Saúde, Ciclos de Vida e Sociedade.

Orientadora: Profa. Dra. Angela Maria Belloni Cuenca

São Paulo

2015 
É expressamente proibida a comercialização deste documento tanto na sua forma impressa como eletrônica. Sua reprodução total ou parcial é permitida exclusivamente para fins acadêmicos e científicos, desde que na reprodução figure a identificação do autor, título, instituição e ano da tese. 


\section{AGRADECIMENTOS}

Tudo começou num carro, voltando de uma reunião do grupo de pesquisa no Rio de Janeiro. Eu estava no banco traseiro e os professores Angela e Ivan na frente, Falávamos da importância de se preparar as novas gerações para a área da pesquisa, das nossas responsabilidades na educação e da ampliação dos desafios com as tecnologias. Nesse momento resolvi cursar o doutorado. Por isso, meu primeiro agradecimento é para eles: Profa. Dra. Angela Maria Belloni Cuenca, minha orientadora, e Prof. Dr. Ivan França Junior.

Meu agradecimento também para os professores que me ajudam a entender a ciência como um processo para se chegar à inatingível verdade. Destaco, da banca de qualificação, as professoras Irene Machado e Vânia Mara Alves Lima; acrescentando, da pré-banca, as professoras Augusta Thereza de Alvarenga e Márcia Thereza Couto Falcão.

Agradeço à Fundação de Amparo à Pesquisa do Estado de São Paulo (FAPESP) pelo financiamento do projeto, que gerou os dados utilizados, e à Universidade de São Paulo (USP), minha casa há tantos anos.

Sem um conforto emocional não seria possível pensar num trabalho que ocupou minha atenção por quatro anos. Esse carinho que me sustenta vem da minha família. Agradeço imensamente ao meu marido Francisco, aos meus filhos Hugo e Gustavo, aos meus pais Hilda e Paschoal, e aos demais familiares e agregados.

Minha experiência e vivência nas bibliotecas foram o estímulo, a motivação, a área, o campo que serviu de base para o estudo. Assim, agradeço a todos os profissionais que conviveram comigo nessa jornada e, sobretudo, à atual equipe da Biblioteca da Faculdade de Saúde Pública pela colaboração e compreensão.

Muito obrigada aos colegas da Faculdade de Saúde Pública por todo o apoio de infraestrutura e amizade.

Finalmente, agradeço aos membros dos grupos de pesquisa NEPAIDS e LIS, que lutaram e lutam intensamente para que as estrelas com HIV brilhem na terra por mais tempo e não precocemente no céu. 
Ainda que eu falasse a lingua dos homens

E falasse a lingua dos anjos

Sem amor eu nada sería

Renato Russo (Legião Urbana), ת Л J J música: Monte Castelo

Ainda que eu falasse as línquas dos homens e dos anjos, e não tíbsse amor, seria como o metal que soa ou como a síno que tíne.

E ainda que tivesse o dom de profecia, e conbecesse todos os mistéríos e toda a ciência, $\mathfrak{e}$ ainda que tínesse toda a fé, de maneira tal que transportasse os montes, $\mathfrak{e}$ não tíuesse amor, nada sería.

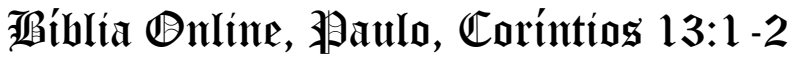


Alvarez MCA. A comunicação científica em saúde: uma abordagem semiótica [tese]. São Paulo: Faculdade de Saúde Pública da USP; 2015.

\section{Resumo}

No cenário da cultura acadêmica e científica em transformação, as bibliotecas indagam os pesquisadores em HIV/aids sobre dificuldades e facilidades na procura de informações. Articulando as disciplinas ciência da informação, saúde pública e semiótica da cultura, este estudo busca analisar o entendimento dos pesquisadores sobre as estratégias de busca de informação técnica e científica nos sistemas bibliográficos. Além disso, identifica os sistemas de signos centrais na semiosfera da cultura e descreve as interações dos pesquisadores com sistemas de informação e bibliotecas, refletindo sobre a comunicação e seus desafios na contemporaneidade. Com base no método semiótico estrutural da Escola de Tártu-Moscou e nos trabalhos de seu maior expoente Iuri Lótman, foram realizadas 25 entrevistas com dois grupos de pesquisa em HIV/aids no Brasil. A diversidade de estratégias do pesquisador sobre a ação de buscar informação científica na contemporaneidade sustenta a dinâmica e a complexidade dos sistemas de signos. As divergências e convergências, traduzidas nas narrativas, explicitam as diferentes linguagens presentes na semiosfera e as tradições de pesquisa. Essas linguagens se transformam, modelizando-se pela variedade de formação acadêmica, atuação profissional e vivências do pesquisador, revelando a complexidade na cultura. No plano da semiosfera, alguns sistemas de signos são vistos como centrais na cultura dos pesquisadores, com destaque para o Google e a base de dados PubMed/MEDLINE. O Google ganha expressão por oferecer um sistema simples e prático, evitando o desperdício de tempo. No entanto, mostra-se um sistema controlado por algoritmos, tendendo ao empobrecimento de resultados e ao domínio comercial. A base de dados PubMed/MEDLINE evidencia sua presença nos códigos da cultura, embora esteja dividindo espaço com o prevalecente Google. Um sistema de signo central para as bibliotecas e pouco conhecido dos pesquisadores é o tesauro MeSH, uma ferramenta que atua de modo invisível por ser complexa em sua utilização. As novas tecnologias ajudam, mas não podem ser supervalorizadas. A administração do tempo e a seleção de informações relevantes para o contexto da pesquisa posicionam os sistemas de informação e bibliotecas como importantes mediadores na comunicação ou tradutores de linguagens. Entretanto, seus papéis ainda não estão claros para o pesquisador. A irregularidade na semiosfera transparece nos movimentos do centro e periferia e assimetrias observadas. A imprevisibilidade promove a transformação e faz parte da consciência do pesquisador, que busca a geração de informação nova. A biblioteca é um sistema presente na busca de informações, mas perde sua centralidade quando projetada para o futuro. Entender a assimetria e a heterogeneidade semióticas envolvidas na cultura acadêmica é uma forma de sobrevivência para as bibliotecas. A luta pela sobrevivência de grupos profissionais se revela nos esforços para manter no centro da semiosfera registros e normas que identificam a cultura. Entretanto, a sobrevivência não se dá somente no fechamento em si, mas no diálogo com o oposto, que promove a criação. As áreas da Saúde e Ciência da Informação se entrelaçam com suas linguagens e modelizações, subdividindo-se em outras modelizações, como a área de prestação de serviços à população, a área acadêmica. A comunicação e a semiótica possibilitam decifrar essa rica diversidade.

Palavras-chave: Semiótica da Cultura; Biblioteca; Comunicação científica; Saúde pública; Semiosfera; Sistemas de informação; Sistemas de signos; Aids; Google; Pubmed, MeSH. 
Alvarez MCA. [Scientific communication in health: a semiotic approach] [thesis]. São Paulo: Faculdade de Saúde Pública da USP; 2015. Portuguese

\section{Abstract}

Within the scenario of the academic and scientific culture undergoing transformation, libraries question researchers in HIV / AIDS as to the difficulty and ease of the search for information. In its articulation of the disciplines information science, public health and semiotic of culture, this study analyzes the understanding of the researchers regarding the search strategies of technical and scientific information in bibliographic systems. It identifies the central sign systems in the semiosphere of culture and describes the interactions between researchers and information and library systems, reflecting on communication and its present-day challenges. Based on the structural semiotic method of the Tartu-Moscow School and the work of its greatest exponent Yuri Lotman, we undertook 25 interviews with two HIV/AIDS research groups in Brazil. The diversity of the researchers' views as to the action involved in seeking scientific information nowadays confirms the dynamics and complexity of the systems of signs. The differences and similarities, as reflected in narratives, explain the different languages present in the semiosphere. These languages undergo continual transformation modeling themselves in accordance with the variety of academic training, professional activity and experience of the researcher, thus revealing the cultural complexity involved. On the plane of the semiosphere, some sign systems are seen as central to the culture of the researchers, especially Google and PubMed / MEDLINE. Google gains in significance as it offers a simple and practical system which avoids waste of time. However, one here perceives a system controlled by algorithms which tends to the impoverishment of results and to commercial domination. The presence of PubMed / MEDLINE is evident in the culture codes, although it is sharing space with the prevailing Google. A key sign system for libraries - though little known to researchers - is the MeSH thesaurus, a tool that works unperceived due to the complexity of its use. New technologies help, but should not be overvalued. Time management and the selection of the information relevant to the research context place information systems and libraries in the position of important mediators of communication or translators of language. However, their roles are still not clear to the researcher. The irregularity in the semiosphere is reflected in the movements of the center and periphery and the asymmetries observed. The unpredictability promotes transformation and is part of the consciousness of the researcher who seeks to generate new information. The library is a system present in the search for information, but loses its centrality when projected into the future. Understanding the asymmetry and the semiotic heterogeneity involved in academic culture is a way to ensure the survival of libraries. The struggle for the survival of professional groups is evident in their efforts to maintain records and norms of cultural identity at the heart of the semiosphere. However, survival is not ensured simply by this closing in on oneself, but it is rather by dialogue with the opposite that creativity is promoted. The areas of Health and Information Science are interwoven with their languages and modeling while at the same time they subdivide into other modelings such as the field of the delivery service to the population and the academic area. Communication and semiotics help decipher this rich diversity.

Keywords: Semiotic of culture; Library; Scientific communication; Public health; Semiosphere; Information systems; Sign systems; Aids, Google, Pubmed, MeSH. 


\section{Sumário}

APRESENTAÇÃO

1 CENÁRIO DA CULTURA E TRANSFORMAÇÕES NO MUNDO CONTEMPORÂNEO

1.1 A SOCIEDADE EM TRANSFORMAÇÃO 14

1.2 SAÚDE PÚBLICA E PROBLEMAS COMPLEXOS 17

$\begin{array}{ll}\text { 1.2.1 Saúde Pública: Tradição e Transformação } & 17\end{array}$

$\begin{array}{ll}\text { 1.2.2 Aids e a Questão da Complexidade } & 20\end{array}$

1.3 A BIBLIOTECA E SEU LOCUS NO CENÁRIO CONTEMPORÂNEO 23

1.4 SOBRE A SEMIÓTICA E COMUNICAÇÃO 27

1.4.1 Sistemas Modelizantes e Textos da Comunicação Científica 30

1.4.2 Linguagem Natural $\quad 32$

1.4.3 Linguagem de Busca dos Programas de Computação 33

1.4.4 Linguagem Documentária: Tesauro ou Vocabulário Controlado 35

1.4.5 Terminologia na Área da Saúde Pública 37

1.4.6 A Estrutura do Texto Científico 42

2 A CONSTRUÇÃO DO OBJETO E AS RELAÇÕES COMUNICAÇÃO E SEMIOSFERA

3 OBJETIVOS 48

3.1 OBJETIVO GERAL 48

3.2 OBJETIVOS ESPECÍFICOS 48

4 PROCEDIMENTOS METODOLÓGICOS 49

4.1 A ESCOLHA DA TEMÁTICA E DOS PESQUISADORES 50

4.2 TRABALHO DE CAMPO E ENTREVISTAS 51

4.3 O PROCESSO DE ANÁLISE DOS DADOS 52

4.4 ASPECTOS ÉTICOS 53

5 RESULTADOS E DISCUSSÃO 54

5.1 CARACTERIZAÇÃO DOS SUJEITOS 54

5.2 A TRÍADE: TEXTOS, SIGNIFICANTES E INTERPRETANTES 59

5.3 O CENTRO DA SEMIOSFERA 66

$\begin{array}{lll}5.3 .1 & \text { Google } & 68\end{array}$

$\begin{array}{lll}\text { 5.3.2 PubMed/MEDLINE } & 72\end{array}$

5.3.3 MeSH: um Símbolo Para Quem? 79

5.4 A INTERAÇÃO DOS PESQUISADORES COM SISTEMAS DE INFORMAÇÃO 89 
5.5 OLUGAR DA BIBLIOTECA NA PERSPECTIVA DE PESQUISADORES

6 SOBRE A COMUNICAÇÃO E DESAFIOS CONTEMPORÂNEOS

7 CONSIDERAÇÕES FINAIS 135

8 REFERÊNCIAS

138

ANEXO: Roteiro da entrevista

CURRÍCULO LATTES 


\section{APRESENTAÇÃO}

Para melhor entendimento do meu interesse por essa área de estudo, convém apresentar brevemente minha trajetória quanto à formação educacional e profissional.

Graduei-me em Biblioteconomia pela Escola de Comunicações e Artes (ECA) da USP em 1984, na fase pós-ditadura, conhecida como abertura política. Filha de operário do $\mathrm{ABC}$ e dona de casa tinha a expectativa de cursar uma faculdade que me garantisse uma estabilidade financeira. Adorava o ambiente das bibliotecas e sua organização e, após algumas consultas, considerei o curso escolhido adequado à minha personalidade e necessidade.

O curso foi além das minhas expectativas, tive a oportunidade de ter contato com disciplinas da área da comunicação, oferecidas nos dois primeiros anos. Essa experiência ampliou o meu conhecimento e me defrontei com uma variedade de temas, discussões, reflexões, que transformaram o meu modo de pensar.

Foi durante o curso que tive contato com as disciplinas de semiótica e fiquei motivada a cursar Letras/Linguística após o término do curso de Biblioteconomia. Entretanto, por motivos pessoais, cursei somente um semestre na Faculdade de Filosofia, Letras e Ciências Humanas (FFLCH) da USP.

Minha trajetória profissional iniciou-se durante o curso de biblioteconomia por meio de estágios. A seguir, atuei como funcionária em algumas bibliotecas da Universidade: Faculdade de Economia e Administração, Instituto de Psicologia, FFLCH e finalmente Faculdade de Saúde Pública (FSP).

Essa experiência profissional em bibliotecas de instituições tão diferentes culturalmente contribuiu para o meu desenvolvimento intelectual.

Trabalhando na Biblioteca da FSP, as perspectivas de aprendizado se ampliaram significativamente com o avanço das tecnologias e com o estímulo para os funcionários continuarem estudando, promovido pela direção da Biblioteca. Assim, participei do curso de Especialização em Saúde Pública e iniciei o meu contato com a área da saúde e sua complexidade. A seguir, participei do curso de Mestrado em Saúde Pública e aprimorei meus estudos na área da comunicação e das novas tecnologias. 
A internet me fascinou pelas facilidades que promovia para as pesquisas e comunicação. Minha dissertação, intitulada "A Biblioteca Virtual de Saúde Reprodutiva: Dando Voz ao Usuário”, foi concluída em 2005 na área de concentração Saúde Materno Infantil do Programa de Pós-Graduação em Saúde pública da FSP/USP.

Minha atuação como bibliotecária na Faculdade, sobretudo no Serviço de Acesso à Informação, proporcionou o contato com muitos usuários, que procuravam informações para desenvolver suas pesquisas acadêmicas e também acompanhavam a evolução das tecnologias de comunicação e informação. Juntamente com os usuários, professores e estudantes de graduação e pós-graduação, e meus colegas da Biblioteca, fui aprendendo como lidar com os microcomputadores, bases de dados, CDs, estratégias de busca, conexões à distância, redes locais e externas e tantas outras possibilidades que foram surgindo.

Esse aprendizado era compartilhado por meio de cursos e treinamentos oferecidos pela Biblioteca à medida que ficávamos competentes no uso dessas tecnologias. Foram muitas as pessoas que participaram do Programa Educativo da Biblioteca. Foi nessa ocasião que eu entendi que nós aprendemos mais quando temos que ensinar e que a grande riqueza do saber é resultado do diálogo do instrutor com o aprendiz.

Nesses contatos com a comunidade acadêmica da FSP, tive a oportunidade de participar de uma pesquisa, que nasceu de projeto aprovado pela FAPESP em 2008. A pesquisa foi coordenada pelo Professor Ivan França Junior e nomeada "Transformações na Comunicação Científica: identificando necessidades e experimentando tecnologias com grupos de pesquisadores em HIV/AIDS". A temática aids, escolhida para a pesquisa, atraiu a minha atenção, por resgatar um tema instigante e amplamente discutido no curso de Especialização do qual participei e acompanhei na literatura.

Essa pesquisa proporcionou-me aprender a estruturar um projeto, acompanhar seu desenvolvimento, participar das atividades metodológicas e de avaliação, conhecer novos instrumentos para comunicação científica, entre outros benefícios incorporados ao meu conhecimento. De natureza qualitativa, essa investigação gerou como resultado um material muito rico em informações, a partir de transcrições de entrevistas, reuniões e simulações. Tendo participado ativamente de todo o processo investigativo, considerei utilizar a experiência gerada num curso de doutorado na FSP. 
Aliado a isso, pude observar a diversidade nas formas de buscar e usar a informação pelos pesquisadores, sujeitos da referida pesquisa. A formação acadêmica deles variava: biomédicos, estatísticos e sociólogos, mostrando pontos de vista diferentes e convergentes.

Como bibliotecária, tive grande interesse em perceber como os pesquisadores procuravam informação em bases de dados para se atualizarem e desenvolverem suas pesquisas. Tomei conhecimento sobre o excesso de informação decorrente das novas tecnologias e as ferramentas que despontavam como fundamentais para os pesquisadores, como o Google, por exemplo. Concomitantemente, percebia que a biblioteca começava a adquirir a imagem de um museu, com preciosidades da cultura, mas perdendo o seu papel de protagonista no processo de pesquisa.

Desta maneira, defini um objeto para estudar: as estratégias de busca nos sistemas de informação. De que forma os pesquisadores procuram informações pertinentes para que haja comunicação entre o que já foi escrito e o que se vai escrever, tendo em vista o contexto das transformações impulsionadas pelos processos digitais dos sistemas informáticos. Minha hipótese é que as transformações estão se intensificando e alterando o papel do profissional bibliotecário.

Assim, no Doutorado, pretendo aprofundar-me na área da semiótica, que tanto me agradou na graduação, e percebendo que o problema poderia estar nos códigos e linguagens de diferentes sistemas de signos, procurei cursar algumas disciplinas para preencher lacunas. Cursei então a disciplina Semiótica da Cultura na ECA, que veio ao encontro das minhas necessidades e expectativas para desenvolver a presente pesquisa.

Essa disciplina colocou-me em contato com uma parte da semiótica, revelando possibilidades de responder a algumas questões que me acompanham há muito tempo nas minhas atividades profissionais em bibliotecas. Com este trabalho, pretendo unir as experiências dessa trajetória, enriquecendo com uma teoria que se descortina de uma procura de compreensão. 


\section{CENÁRIO DA CULTURA E TRANSFORMAÇÕES NO MUNDO CONTEMPORÂNEO}

O cenário, em linguagem figurada, é uma grande cidade, crescendo rapidamente e desordenadamente, e abrigando complexas redes de relacionamentos, reais ou virtuais. Fluxos intensos de pessoas, veículos, objetos se entrecortam e desenham o perfil desse ambiente. Para alguns, a percepção desse cenário é de medo, por considerarem impossível decifrar os signos que se apresentam em quantidade extraordinária, para outros é de descaso, por não perceberem os sinais e a informação nova ou por serem mais seletivos.

Esse cenário está em crescimento por todos os lados, as cidades crescem nas periferias e ao mesmo tempo na verticalidade das edificações que se erguem para cima e se aprofundam nos subterrâneos. Assim como o crescimento físico está desordenado, as informações estão se proliferando em novas dimensões.

A cidade, metaforicamente falando, pode ser interpretada como um macroorganismo em desenvolvimento. Do alto, podem-se observar suas vias, seus movimentos, seus núcleos. À noite, as luzes contribuem para reconfigurar esse cenário, explicitando suas obstruções e extensões.

Algumas instituições procuram explicar os fenômenos da natureza e da cultura de forma mais sistematizada e regulamentada. São elas, as universidades com seus institutos de pesquisa e faculdades, cuja comunidade acadêmica gera conhecimento a partir da informação para tentar entender a vida e seus processos. Grupos de pesquisa trabalham para construções e transformações da natureza, sobrevivência da espécie humana e compreensão das culturas.

Nas universidades há divisões culturais na aquisição do conhecimento. Há tempos é explorado o fato de não haver comunicação efetiva entre as ciências e as humanidades: "essa dialética complexa entre ciência pura e ciência aplicada é um dos problemas mais profundos da história científica" (SNOW, 1995, p.92). Trata-se da discutível dicotomia entre ciências puras e aplicadas.

No mundo acadêmico, as implicações referentes à informação, pesquisa e conhecimento se desenvolvem crescentemente e se inter-relacionam com os estoques de informação institucional ou sistemas de informação ou, ainda, bibliotecas. 
As bibliotecas nas universidades seguem o padrão cultural das unidades a que estão ligadas. A área da saúde, por necessidade de lidar com a sobrevivência humana, interage fortemente com as novas descobertas para o desenvolvimento tecnológico em diagnósticos e tratamento de doenças, demandando informações atualizadas para e de seus pesquisadores. Desse modo, profissionais da informação vêm acompanhando e contribuindo com o desenvolvimento das tecnologias da informação e comunicação que ocorreram acentuadamente a partir do pós-guerra, culminando com a internet.

A internet é um sistema aberto, que proporcionou a comunicação entre os estoques de informação pelo funcionamento interligado em sistemas de rede. As interfaces de comunicação entre os sistemas e os usuários da informação estão se tornando cada vez mais amigáveis e interativas (ROWLEY, 2002). A necessidade de uma comunicação mais ampla e globalizada promoveu esse desenvolvimento.

A sociedade em transformação reformula o cenário a cada momento e os sistemas de informação e a comunicação se desenvolvem, contribuindo na globalização, nas mudanças nos padrões de emprego, na responsabilidade pelo custo da informação, nas questões de direito autoral e propriedade intelectual, na segurança e proteção dos dados e nos padrões e controle bibliográfico (ROWLEY, 2002).

O cenário acadêmico torna-se mais complexo com as transformações tecnológicas e conceituais, levando a questionamentos sobre conceitos de ambiente e cultura, que serão abordados mais à frente. 


\subsection{A SOCIEDADE EM TRANSFORMAÇÃO}

A sociedade vive em constante transformação juntamente com o ambiente. A possibilidade de se comunicar com pessoas em vários locais do planeta em tempo real, formando redes de conexão, viabilizadas pela microeletrônica, fez emergir a chamada sociedade em rede.

A sociedade em rede, para CASTELLS (2009), nasceu de três processos independentes na década de 1970: a crise e reestruturação do industrialismo, os movimentos sociais e culturais de liberação e a revolução das tecnologias de informação e comunicação. As redes trabalham com protocolos de comunicação, competem e cooperam entre si e se transformam para a superação ou destruição.

Os pilares para a organização da sociedade em rede foram a flexibilidade, a adaptabilidade e a capacidade de sobrevivência. A mente e o corpo dos humanos receberam uma extensão nas redes de interação e são a base da nova estrutura social (CASTELLS, 2009).

Nessa sociedade em transformação os desafios são vários, sendo o principal deles a reforma do pensamento, que interage com a reforma na educação (MORIN, 2004).

De nada adiantaria viver numa sociedade em rede se isso não promovesse o aumento da qualidade de vida e do conhecimento humanos. Para MORIN (2004), o conhecimento é uma "tradução e reconstrução, a partir de sinais, signos, símbolos sob a forma de representações, ideias, teorias, discursos", feita por uma mente numa cultura, e comporta ao mesmo tempo, separação e ligação, análise e síntese (p.24). Ele defende a necessidade de integrar conhecimentos em seu contexto global e fragmentar menos os conhecimentos particulares.

Os estudos de MORIN aprofundam a ideia de globalidade relacionada à complexidade do pensamento (complexus - o que é tecido junto). Essa complexidade traz desafios para a sociedade e entre eles "o da expansão descontrolada do saber" e o sentimento de que "estamos afogados em informações", seja nas ciências ou nas mídias (2004, p.16).

A fragmentação do saber não resolve a problemática do excesso de informação, ao contrário, o amplia. Uma proposta é um pensamento que une, diferente do 
pensamento reducionista. Algumas tentativas de união dos pensamentos e disciplinas não conseguiram promover essa ligação, pois houve mais justaposição e conflitos e menos busca de uma linguagem comum. MORIN (2004) cita o exemplo nas ciências cognitivas com o elo entre cérebro, mente e computador (biologia, antropologia e inteligência artificial).

Numa sociedade urbana em transformação intensa, novos questionamentos se posicionam na filosofia e na ciência. Pesquisadores, pensadores, cientistas reúnem-se para refletir sobre a ciência moderna nas tentativas de acompanhar o objeto em movimento.

Nesse sentido, a ligação do contexto com o objeto torna-se fundamental, uma vez que o contexto determina a predominância de interpretação num processo comunicacional. A noção de contexto tem sido usada de diferentes maneiras pelos pesquisadores, mas, para o semioticista $\operatorname{SEBEOK~(1997,~p.~58),~o~"termo~se~refere~ao~}$ reconhecimento pelo organismo das condições e maneiras de usar apropriada e efetivamente as mensagens".

Com base nos estudos do mesmo autor (SEBEOK, 1997), no processo comunicacional o contexto pode ser crucial para resolver os seguintes impasses:

- A significância da mensagem, quando um objeto de pesquisa atende a um determinado grupo específico. O contexto deixa claro para os demais grupos que o objeto se refere a uma situação particular.

- A credibilidade da mensagem. O contexto pode determinar se o destinatário acredita na comunicação recebida, nem sempre um achado é considerado importante ou verdadeiro para uma determinada cultura.

Entretanto, algumas vezes, o contexto atua de forma negativa, impedindo a interpretação do conteúdo da comunicação, quando a forma já está estabelecida como rotina. SEBEOK (1997) apresenta o exemplo dessa situação: todas as manhãs um psicólogo entra num elevador e cumprimenta as pessoas presentes com um sorriso, dizendo "bom dia", sendo retribuído com um "bom dia" dos demais; em determinado dia, porém, ele faz uma experiência e diz "vão para o inferno" com um sorriso e é retribuído com um "bom dia". Nesse caso, o contexto repetitivo e estruturado naquele ambiente, mesmo com mensagens contraditórias (frase agressiva e sorriso/entonação agradáveis) impediu o entendimento verdadeiro do conteúdo da mensagem oral. 
Essas situações ilustram a importância do estudo do contexto para o bom entendimento das mensagens e dos objetos.

Assim, no contexto da sociedade em rede, que se caracteriza por uma modelização social intensa da tecnologia e interesses comerciais e governamentais, estudar as formas de pensar e comunicar adquire maior importância por se interrelacionarem com os estudos sobre a preservação da natureza e da cultura.

A diversidade das espécies é defendida intensamente por biólogos e ecologistas na contemporaneidade como forma de assegurar a operação de todos os "nichos-chave funcionais" e precaver-se nos momentos estressantes (ODUM \& BARRETT, 2011, p.38). Essa diversidade só será possível se houver um esforço também de preservação da diversidade das culturas, ou seja, as linguagens e códigos culturais. A luta deve ser para que a globalização, sociedade em rede e tecnologias promovam a coexistência cultural, ao contrário da uniformização das culturas, conceito mencionado por MACHADO como "semiodiversidade" (2003a, p.183). 


\subsection{SAÚDE PÚBLICA E PROBLEMAS COMPLEXOS}

\subsubsection{Saúde Pública: Tradição e Transformação}

A área da Saúde Pública constitui-se por uma complexa relação do Estado, sociedade, saúde e meio ambiente e tem passado por transformações importantes na sua história. Seu objeto é amplamente discutido por pesquisadores, dividindo-se em caracterizá-lo numa abordagem das ciências humanas ou num enfoque biotecnológico (PAUL, 2005). Na medicina, a preservação da vida é mais focada no indivíduo, enquanto que na saúde pública se direciona para o coletivo, social.

Um objeto de estudo preponderante da saúde é justamente o seu contrário: a doença. O homem enfrenta problemas com as doenças desde os primórdios e seus estudos voltam-se para "o controle das doenças transmissíveis, a melhoria do ambiente físico (saneamento), a provisão de água e alimentos puros e em volume suficiente, a assistência médica e o alívio da incapacidade e do desamparo" (ROSEN, 1994, p. 31).

Em cada período histórico, a saúde pública centrou-se em alguns problemas, embora eles estejam acometendo as populações em movimentos cíclicos ou contínuos até a atualidade. Assim, se na Grécia e Roma da antiguidade o foco estava nas doenças decorrentes da falta de saneamento, também nas mesmas culturas era observado o registro de preocupações com a saúde ocupacional e com o abastecimento de água, como os aquedutos romanos, que distribuíam água pelas cidades. Por outro lado, ainda hoje temos regiões com carência de água e falta de saneamento no planeta.

Na Idade Média, a ocorrência das grandes pragas, como a lepra e outras epidemias, tomava a atenção de autoridades, na época, religiosas, que precisavam adotar medidas de contenção das doenças. No Renascimento, novas descobertas, novas manifestações de doenças, destacando a sífilis e o escorbuto, decorrentes do Mercantilismo, que se juntaram às antigas e continuam a ser problema na atualidade (ROSEN, 1994).

O período de 1750 a 1830 é considerado por ROSEN (1994) como os 80 anos de grande evolução para a saúde pública. Esse período, marcado por revoluções e recuperações, principalmente na Europa, trouxe melhorias na vida urbana, a descoberta das primeiras vacinas, os registros de nascimento e morte, as fundações do movimento sanitário. Em seguida, na era industrial (1830-1875), houve um desdobramento negativo 
para a saúde das populações mais pobres, considerado o momento do controle, das inspeções sanitárias e do aumento do urbanismo. ROSEN (1994) nomeia de "era bacteriológica" o período a partir de 1875, quando a ciência e os estudos da química se desenvolveram e contribuíram para a descoberta do antibiótico. Problemas infecciosos resolvidos e mais uma preocupação surge em saúde pública: as doenças crônicodegenerativas, que se evidenciam a partir da segunda metade do século XX.

A população, com a expectativa de vida maior, começou a ser acometida por outras doenças: as cardiovasculares e as neoplasias, sem esquecer as doenças mentais. Conhecida como transição demográfica, trata-se da emergência de um grupo populacional antes pouco estudado, a "terceira idade", trazendo novos desafios para a saúde pública (PATARRA, 1994). Vários fatores envolvem essa transição, como o controle da natalidade e os contraceptivos orais.

As questões relacionadas à alimentação se incorporam à saúde pública e se apresentam como problemas nutricionais relevantes. Ao lado dos antigos problemas da fome, novos emergem, como é o caso da obesidade, que passam a ganhar expressão nos estudos acadêmicos (MONTEIRO, 2000).

A chamada transição epidemiológica é bastante relatada pela literatura em saúde pública, seja no mundo, no Brasil (PRATA, 1992) ou nos municípios (BUCHALLA e col., 2003). As doenças por causas externas (acidentes, violência) ganham destaque na saúde, ao lado das doenças crônico-degenerativas.

Os estudos sobre meio ambiente sempre permearam os demais assuntos da área da Saúde Pública. Mais recentemente, o foco na preservação do meio ambiente tem se ampliado para estudos de sustentabilidade, que se caracterizam pela democratização e coletivização das responsabilidades pelo uso e conservação do meio ambiente (FARIA, 2012). Grosso modo, há uma tendência de estudos que inter-relacionam a sociedade e o ambiente e menos estudos que isolam essas disciplinas.

As questões políticas e administrativas, relacionadas à saúde, são acompanhadas de movimentos e transformações, e ganharam destaque nos estudos de saúde pública no Brasil a partir do século XX, culminando com a Reforma Sanitária e a aprovação da Constituição brasileira em 1988 (CARVALHEIRO e col., 2013).

A partir do processo de Reforma Sanitária, outras abordagens teóricas e metodológicas foram observadas na área da saúde. Para citar um dos exemplos, 
podemos pontuar o trabalho de ALVARENGA (1994), quando destaca, em sua análise sobre a natureza interdisciplinar da saúde pública, os seguintes objetos: a clássica tríade saúde-doença-morte e as emergentes Políticas de Saúde e Planejamento Estratégico.

Essa síntese da área da Saúde Pública pretende ilustrar o cenário em que se encontra a pesquisa acadêmica, sua movimentação acelerada e transformação aleatória. Embora pesquisadores tentem isolar o objeto da saúde pública num reducionismo científico metodológico para simplificar a leitura dos fenômenos, característica do pensamento positivista, o sujeito transparece e articula-se com o objeto, como bem demonstra PAUL em seus estudos $(2005,2013)$. O objeto não é somente a doença, mas a sua prevenção e, assim, riscos e vulnerabilidade dos seres humanos devem ser considerados (AYRES e col., 2003). Isso porque, o humano e grupos humanos são múltiplos, vivem em ambientes diversos, trazem uma memória dos signos e códigos culturais e uma potencialidade criativa e imprevisível como considera LÓTMAN (1999) em seus estudos semióticos.

Assim, o objeto da saúde pública se apresenta como um objeto complexo, pertinente às áreas biológica e social, revelando sua natureza não somente interdisciplinar, mas igualmente transdisciplinar na leitura que dela faz ALMEIDA FILHO (1997, 2005) e PAUL (2013). A saúde pública está sendo construída na cultura como uma disciplina, que interage fortemente com outras, como a medicina, a ecologia, a engenharia sanitária, a política e a biologia. Para ALMEIDA FILHO (1997, 2005), o objeto complexo da saúde pública consiste, portanto, não na dicotomia saúde-doença, mas no complexo saúde-doença-cuidado e exige, para tal, não só sua compreensão como processo de conhecimento, mas, igualmente, como processo de intervenção.

A complexidade característica do campo da saúde pública leva a observar a coexistência na produção científica de formas diferenciadas de conhecimento, quais sejam, ao lado da disciplinaridade, a multidisciplinaridade, a interdisciplinaridade e mesmo a transdisciplinaridade (LUZ, 2009; ALMEIDA FILHO, 2005; PAUL, 2013, SOMMERMAN, 2012).

A natureza teórica e prática da saúde pública direciona as pesquisas para duas lógicas: "uma teórico epistemológica de produção de conhecimento, seja ela interpretativa ou explicativa" e uma "lógica operativa e pragmática da eficácia, decorrente da intervenção normativa na ordem da vida, no sentido da erradicação ou controle do adoecimento coletivo" (LUZ, 2009, p.306). Daí, a colocação de 
CARVALHEIRO e col. (2013), quando afirmam que os grandes desafios no campo da Saúde Pública/Saúde Coletiva é o de contemplar a complexidade dos fenômenos, quer nos processos de produção do conhecimento, quer na definição de políticas públicas.

\subsubsection{Aids e a Questão da Complexidade}

O surgimento da síndrome da imunodeficiência adquirida (aids) corroborou com esses pensamentos sobre interdisciplinaridade. Essa doença, sexualmente transmissível, surgiu num momento histórico de preocupações epidemiológicas com as doenças crônico degenerativas nas áreas urbanas. Sua transmissão, inicialmente incontrolável, e alta mortalidade desafiaram a sociedade e os cientistas. $\mathrm{O}$ objeto é complexo por se caracterizar como interdisciplinar, agregando diferentes culturas de pesquisadores com variadas formações acadêmicas.

Nesse sentido, as afirmações de HERZLICH (2004) permite-nos apontar para a complexidade que reveste essa área de estudo, rompendo com a dicotomia saúde pública/medicina e trazendo para a esfera pública a esfera do privado, ao dar visibilidade ao sujeito-paciente como sujeito de direitos. Isso pelo fato dessa epidemia ter possibilitado o empoderamento de pessoas vivendo com HIV/aids, articulando de maneira estreita as contribuições das ciências naturais e das ciências humanas e sociais.

Assim, a partir de uma vertente biológica, como o vírus HIV transmissor da doença aids, o objeto passou a ser abordado nos contextos políticos e sociais. Diferentes desdobramentos foram ocorrendo e estão ainda presentes nas ações e estudos sobre essa doença, destacando-se os temas: política de redução de danos, preconceito, sexualidade, direitos reprodutivos, drogas injetáveis e tantos outros.

No Brasil, os primeiros casos dessa doença foram notificados em São Paulo na década de 80, vinculados ao grupo de homens que fazem sexo com homens e se disseminou rapidamente para outros grupos sociais como mulheres e homens com práticas heterossexuais (SECRETARIA DA SAÚDE DO ESTADO DE SÃO PAULO, 2008). A partir de então, a doença foi adquirindo novos contornos na sociedade e na pesquisa, revelando a sua complexidade. A transmissão por transfusão de sangue, drogas injetáveis e vertical (mãe-filhos) ampliou as frentes da assistência, envolvendo 
novos profissionais. Ao mesmo tempo, pesquisadores químicos, médicos e biólogos estudavam novas formas de tratamento.

Muito se estudou e ainda se estuda sobre essa síndrome e suas implicações. Em buscas realizadas nas principais bases de dados da área biomédica (Lilacs e MEDLINE/PubMed) observa-se grande quantidade de trabalhos publicados sobre o assunto, cujos dados estão apresentados na figura 1 .

Figura 1 - Quantidade de trabalhos científicos recuperados nas bases Lilacs e MEDLINE com o descritor aids, 1982-2009.

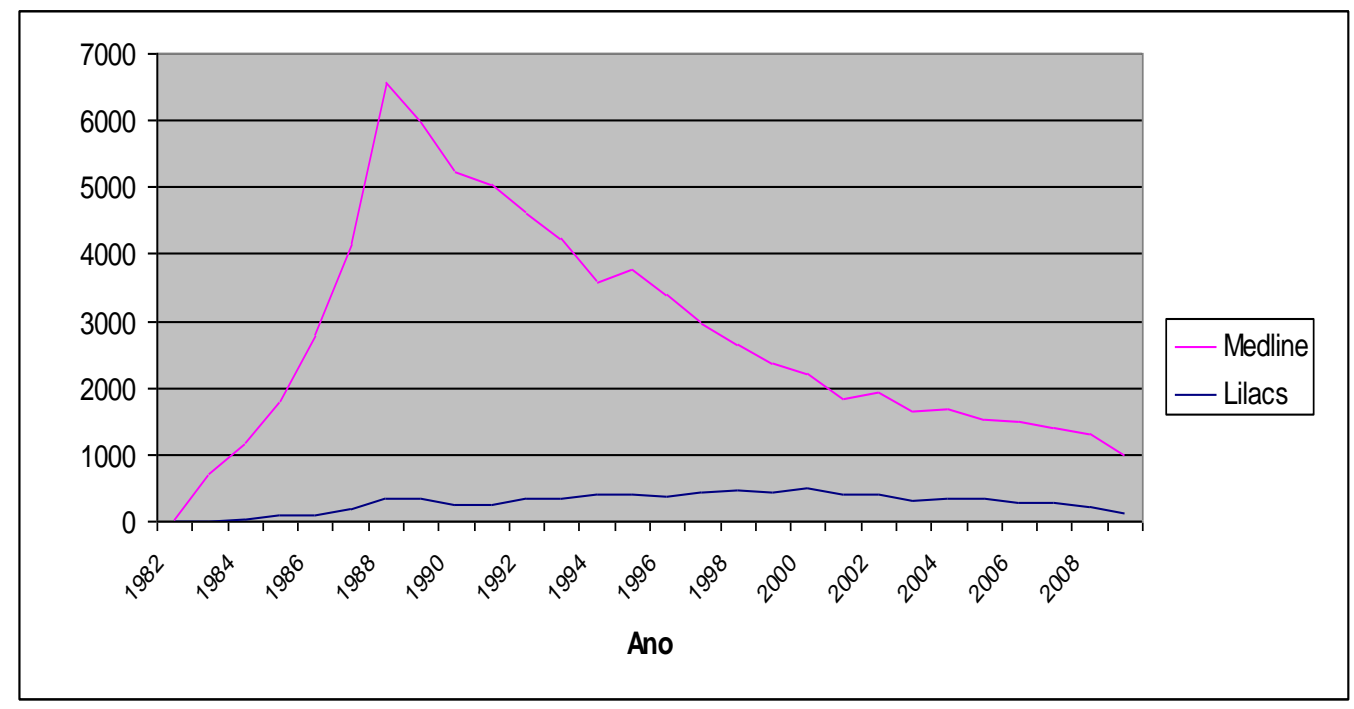

Apesar do declínio no número de publicações, observado a partir do ano de 1991, ainda é grande o número de pesquisas voltadas a essa doença. No decorrer do tempo, o assunto se desdobrou em outros, conforme o desenvolvimento das pesquisas. Nesse caso, reconhece-se uma dinâmica na terminologia: o descritor HIV começou a ser mais explorado nos trabalhos a partir do ano 2000. Esse movimento ocorreu devido ao foco das pesquisas ter sido desviado para o agente da doença, em estudos sobre o combate e a evolução do vírus HIV, uma vez que a doença parece estar mais controlada pelos biomédicos.

O descritor aids, quando comparado com outro, também bastante estudado na área da saúde, como hipercolesterolemia, apresenta diferença significativa nas quantidades de trabalhos publicados (Figura 2). 
Figura 2 - Quantidade de trabalhos científicos recuperados sobre aids e hipercolesterolemia, 1990-2010.

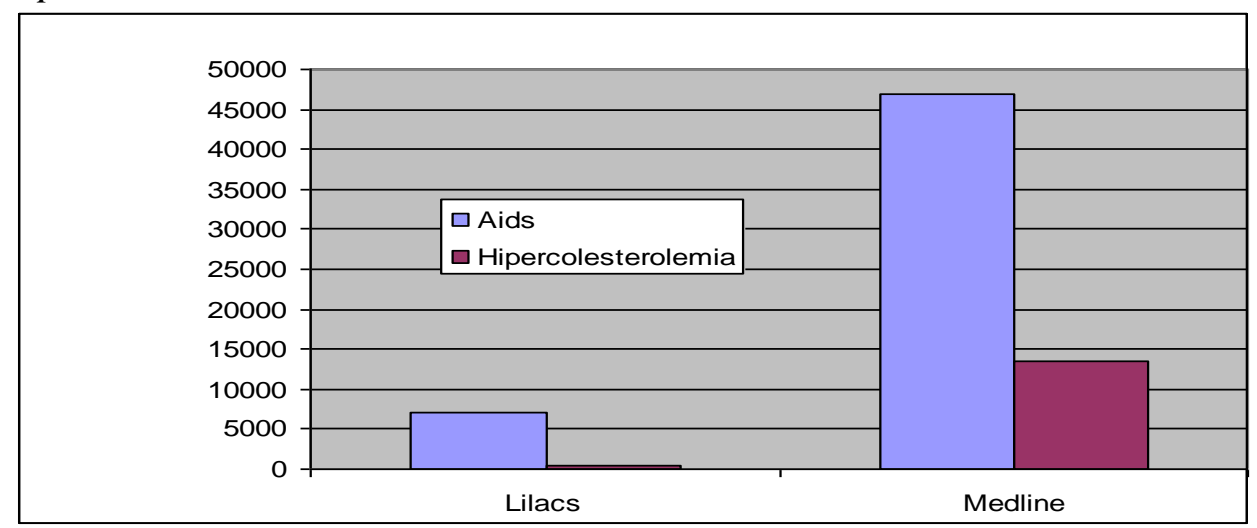

Considera-se que os grupos de pesquisadores em aids, por necessidade de atualização constante e pela dinâmica e interface com várias disciplinas, apresentam-se como grandes colaboradores para o desenvolvimento de pesquisas sobre recuperação de informação científica.

Desde o surgimento da aids, equipes multidisciplinares se formam para buscar respostas aos problemas que surgem. A população acometida pela aids reivindica seus direitos aos medicamentos, que são desenvolvidos, e seus direitos reprodutivos e sociais. Os médicos orientam os pacientes, portadores do HIV, a usarem preservativos para evitar novas infecções e a seguir um tratamento difícil, com vários efeitos colaterais. Os psicólogos e sociólogos ouvem o desejo dos pacientes de ter filhos, constituir família, as mulheres querendo amamentar os filhos (PAIVA e col., 2002). Devido a esses conflitos, cientistas buscam soluções, como criar um medicamento que impeça a transmissão vertical e tantas outras questões que seguem se reproduzindo.

Esses grupos multidisciplinares são protagonistas das pesquisas que se configuram, muitas vezes, como interdisciplinares, enfrentando desafios metodológicos. Dessa forma, são grupos experientes em trabalhos com diferentes culturas acadêmicas e potenciais sujeitos para análise de estudos em grupo. 


\subsection{ABIBLIOTECA ESEU LOCUS NOCENÁRIOCONTEMPORÂNEO}

Focando no ambiente acadêmico, observamos os desafios dos pesquisadores na lida com a grande quantidade de informações, as diferenças culturais, o acesso e pertinência da produção científica, as dificuldades em entender as linguagens tecnológicas e as bases de dados especializadas, assim como conviver com a interdisciplinaridade e a transdisciplinaridade.

Bibliotecários tentam contribuir para minimizar as dificuldades dos pesquisadores na busca e no uso da informação. A busca por informação acontece em todas as fases da pesquisa, da proposição do tema à descoberta e à divulgação dos achados. As bibliotecas atuam como suporte para grupos de pesquisa, como depositária de acervos (impressos e digitais) e mediadora, tornando o acesso aos acervos possível e facilitado. Para MEADOWS (1999, p. 134): "uma das funções primordiais das bibliotecas é de atuarem como depositárias de publicações, de modo que os cientistas possam ter acesso a informações publicadas no passado, bem como as que estão sendo editadas no presente".

A questão das bibliotecas como bem público é discorrida por DARNTON (2010) em ensaios formulados para inspirar reflexões. Para ele, as bibliotecas têm o papel de promover o bem público, encorajando o saber e defendendo a educação "aberta para todos" apregoada pelo Iluminismo. Com a possibilidade de digitalizar acervos e dispor seus livros com acesso aberto por meio da internet, o sonho de democratizar o conhecimento parece estar se tornando uma realidade. Entretanto, DARNTON traz à tona os interesses das empresas, editoras do material bibliográfico, bem menos românticos, voltados a gerar lucros aos seus acionistas.

As bibliotecas, além de depositárias, se integram a sistemas de informação para processar e divulgar informações especializadas e validadas para públicos específicos, produzidas institucionalmente. Por outro lado, as bibliotecas são também usuárias e clientes de sistemas de informação; usuárias, quando acessam os sistemas para auxiliar os seus usuários na busca por informação científica, e clientes, quando pagam pelo acesso a sistemas de informação para atender os seus usuários.

O principal produto dos sistemas de informação são as bases de dados bibliográficas. Uma das etapas da pesquisa científica é a recuperação da informação em bases de dados bibliográficas, que é objeto de trabalho do profissional bibliotecário. Os 
sistemas de recuperação da informação compreendem as etapas de indexação, armazenamento e recuperação (ROWLEY, 2002). As responsabilidades pela indexação e armazenamento nos sistemas de informação ainda são quase que exclusivas do profissional da informação, mas a recuperação da informação especializada, propriamente dita, pode ser feita pelo pesquisador com autonomia nos recursos de busca. A consulta pode ser feita de qualquer lugar, não somente no ambiente físico das bibliotecas (CUENCA e col., 2013).

A internet possibilitou ao pesquisador realizar suas buscas nas bases de dados online, sem a intermediação dos bibliotecários, considerado por MIRIM (2004) uma inovadora e revolucionária forma de busca, uma vez que nem sempre é possível traduzir as necessidades de informação do pesquisador ao profissional e nem sempre há um bibliotecário disponível para isso. Antes da internet, a oferta de informação se resumia aos acervos impressos de livros e revistas científicas com a busca feita em fichários e bibliografias impressas. Com a internet, parte dos impressos se transformaram em digitais, oferecidos intensamente à comunidade científica e acadêmica, principalmente por intermédio das bibliotecas.

Com os repositórios institucionais se proliferando como solução de armazenamento e de permanência do saber acumulado, a participação de pesquisadores nas etapas de indexação e armazenamento nos sistemas tende a aumentar. Os repositórios possibilitam aos pesquisadores o autoarquivamento de seus trabalhos, bem como a atribuição de metadados e indexação temática de seu domínio, promovendo, assim, mudanças no ciclo da comunicação científica. Daí, empresas de informática desenvolvem novas ferramentas na internet para o pesquisador realizar suas buscas, armazenar e organizar a informação recuperada, sem a intermediação do bibliotecário. São programas conhecidos como Endnote Web, Zotero, Connotea, entre outros. Segundo HULL e col. (2008) o desenvolvimento desses instrumentos é importante para tornar as bibliotecas digitais mais acessíveis e úteis para os pesquisadores.

Com tantos instrumentos disponíveis espera-se que a recuperação da informação não seja um problema na pesquisa. Porém, ainda se depara com pesquisadores frustrados com o excesso e irrelevância da informação (HEY e col, 2011). É uma contradição na comunicação: pouca informação útil no meio de muita informação disponível. 
Usuários nas bibliotecas consultam o resultado de suas buscas em bases de dados, tecnicamente bem elaboradas, concluindo a irrelevância dos itens recuperados. Somente uma pequena porcentagem interessa realmente para sua pesquisa. Disso decorre, além desse resultado negativo, algumas vezes, mudança de foco nos projetos de pesquisas, sendo considerado positivo por contribuir para a delimitação do tema. A imprevisibilidade levando às novas descobertas.

As falhas na recuperação, segundo SARACEVIC (2008) decorrem de responsabilidade humana: questões mal formuladas e interpretadas, indexação e recuperação mal conduzidas. Lancaster, citado por SARACEVIC (2008), analisou em 1969 a base de dados MEDLINE (MEDLARS na época) e os resultados apontaram duas falhas: de revocação (documentos importantes não foram recuperados) e de precisão (documentos recuperados que não foram importantes). Esse mesmo problema ainda ocorre atualmente.

As buscas bibliográficas e a interação humano-computador envolvem grande quantidade de decisões humanas, mesmo em sistemas sofisticados e automatizados. SARACEVIC (2008) lamenta e credita os poucos estudos a respeito à complexidade envolvida, ao tempo consumido e à impossibilidade de ser feito automaticamente por computador.

A base do sistema de recuperação de informação é prover o usuário com informação o mais relevante possível e relevância é uma noção humana. Segundo RATZAN, 2004, a relevância estabelecida por humanos está carregada de problemas e inconsistências no julgamento. A determinação da relevância é frequentemente um processo incerto e a representação da informação é muitas vezes inadequada e incompleta (RATZAN, 2004).

A teoria da relevância em comunicação é um enfoque voltado ao estudo da recuperação da informação. SARACEVIC (2007a, 2007b) retomou essa teoria, desenvolvida por ele em 1975, em dois trabalhos de revisão, três décadas depois, para fundamentar a ciência da informação. Assim como a ciência da informação, a teoria da relevância em comunicação vem de uma tradição interdisciplinar, interagindo com a linguística, semântica, cognição e filosofia.

Assim, algumas questões se colocam: por que nem todos os registros recuperados são relevantes? Por que alguns pesquisadores preferem consultar 
buscadores na internet, como o Google, ao invés de bases de dados especializadas? O que a internet influenciou na relação entre o bibliotecário e o usuário da informação (pesquisador)?

O acesso, a recuperação e a divulgação da informação são etapas de um ciclo que se perpetua. Nesse contexto, os desafios e dificuldades se destacam com a tecnologia e a velocidade com que o ciclo se completa. Na elaboração da escrita do trabalho para sua divulgação, o pesquisador se depara com outras dúvidas, por exemplo:

- A estrutura formal do trabalho - que modelo usar? IMRD (introdução, metodologia, resultados e discussão), trabalho discursivo, ensaio?

- Onde publicar? Revistas, livros, capítulos, anais de congressos?

- As normas bibliográficas e de citação - que modelo usar? Que ferramentas tecnológicas estão disponíveis para facilitar a organização das referências?

Nos serviços de referência de bibliotecas universitária, o bibliotecário tem como atividade esclarecer sobre os padrões formais adotados na instituição para a escrita do trabalho, bem como oferecer as possibilidades de títulos de revistas científicas convenientes para a submissão do manuscrito. Nesse momento, devem ser observadas as questões relacionadas às políticas de produção acadêmica, como: qual revista tem impacto maior quanto à citação pelos pares? Se eu publicar em determinada revista, a instituição terá melhor nota nas instituições de avaliação do país?

Outra questão se coloca: o bibliotecário está preparado para dialogar com o pesquisador, entender suas demandas e dificuldades e contribuir efetivamente? 


\subsection{SOBRE A SEMIÓTICA E COMUNICAÇÃO}

Para buscar explicações a essas indagações sobre a comunicação científica e o papel das bibliotecas no processo é preciso ter como base um referencial teórico. $\mathrm{O}$ referencial teórico da ciência da informação ainda está em construção. Seu estudo tem se desenhado como a "informação como objeto", como define BUCKLAND (1991), ou a informação como processo para chegar ao conhecimento. Esse refinamento no objeto é necessário para evitar seu compartilhamento com as demais áreas do conhecimento, uma vez que informação é objeto de toda a ciência.

Além disso, a ciência da informação tem origem recente, 1968, e por ter sido orientada a responder a uma necessidade social e demandar de tecnologia da informação e máquinas de comunicar, dirigiu seus pesquisadores mais para a prática e pouco para a questão teórica. Assim, não houve ligação entre o empírico e o teórico. Isso justifica a emergência de interdisciplinaridade nos estudos relacionados à ciência da informação (LE COADIC, 1996). Entretanto, não somente a interdisciplinaridade, como atestam SOMMERMAN (2012), ALVARENGA e col. $(2011,2015)$ em seus estudos sobre a emergência e consolidação das propostas de interdisciplinaridade e transdisciplinaridade como formas ou modos alternativos e complementares à ciência disciplinar, diante dos desafios colocados pelos fenômenos complexos à ciência contemporânea.

Em termos específicos, para que a comunicação se efetive entre os sistemas de informação e seus usuários é necessário que os critérios, que nortearam a transformação da informação pelos sistemas, sejam disponibilizados para os receptores (usuários). De outro modo, podemos dizer que o conhecimento dos códigos e linguagens é fundamental para a efetivação da comunicação.

As ciências da comunicação estão atravessando uma crise teórica pela dificuldade de delimitar seu campo disciplinar, objeto e método, segundo MACHADO e ROMANINI (2010). A concepção tradicional de comunicação de Shannon, como um modelo matemático linear, não sustenta mais a complexidade dos fenômenos comunicativos e o compartilhamento de sentido entre indivíduos. Esses autores propõem uma nova abordagem para a comunicação, nomeando de semiótica da comunicação.

A semiótica da comunicação é "um processo interativo num universo composto por sistemas e subsistemas abertos, organizados por meio de fluxos de informação, em 
que a ação dos signos, ou semiose, é o fenômeno fundamental". A semiose é a ação dos signos numa abstração profunda, que se manifesta como ato de conhecimento do mundo, num processo de modelização, desde a percepção até a representação. Ela é um fenômeno e ação integradora, "que permite interação em diferentes escalas do inanimado ao animado" (MACHADO e ROMANINI, 2010, p. 93).

Essa reflexão, buscando a compreensão do fenômeno da semiose, direciona para a área da semiótica. Segundo ECO (1990), a semiótica ocupa-se dos signos como sua matéria-prima, suas relações com códigos e inseridos em unidades mais amplas como o enunciado, a retórica, a função narrativa, entre outras. O signo, numa definição de dicionário, é aquilo que representa algo. A semiótica é uma técnica de pesquisa que estuda o funcionamento da comunicação e significação.

Unindo-se a isso, no contexto deste trabalho, outro ponto a destacar é a forte presença de características culturais distintas tanto no grupo de pesquisadores, quanto no grupo de bibliotecários, mesmo atuando numa mesma instituição. $\mathrm{O}$ contexto onde se processa a comunicação desses grupos torna-se fundamental para o entendimento do objeto da presente pesquisa.

Com base nesse raciocínio, uma possibilidade teórica a ser considerada é a semiótica da cultura, desenvolvida por semioticistas da Escola de Tártu-Moscou, a partir dos anos 1960. Esse ramo da semiótica preconiza a investigação semiótica orientada pela compreensão da linguagem com base nos vários sistemas de signos da cultura. Os estudos dessa Escola envolvem discussões, que abarcam a interdisciplinaridade, avizinhando-se cientificamente com a teoria da informação e da comunicação e com a cibersemiótica; portanto, relaciona-se com o objeto que se desenha nesta pesquisa, que é a própria comunicação.

O principal expoente dessa Escola foi Iúri M. Lótman (1922-1993). Nascido na Rússia, ele mudou-se para Tártu, após a Segunda Guerra, para evitar as perseguições aos intelectuais judeus na época de Stálin. Seus estudos abrangeram as áreas da história, cultura, literatura, com influência das ciências exatas e, curiosamente, também dos estudos entomológicos, que serviram de base e material para análise da cultura humana. A interdisciplinaridade foi um traço importante da sua obra e da época na qual esteve inserida a sua criação (AMÉRICO, 2012). 
A produção bibliográfica de Lótman é extensa e diversificada, incluindo estudos da literatura e cultura russas, comunicação humana, semiótica da cultura etc. Na primeira fase, seu foco de interesse foi nos estudos literários, o segundo momento teve origem na $4^{\mathrm{a}}$. Escola de Verão, intitulada Semiótica e Cultura, e a partir de então Lótman se aprofundou no estudo da função da cultura e desenvolvimento de novos conceitos, como semiosfera, cultura e explosão (CÁCERES SÁNCHEZ, 1996).

Nesse contexto, outros trabalhos de análise de diferentes formas de comunicação podem ser mencionados, como jornalismo hipermídia, argumentação gráfica na comunicação da ciência e estudo literário, que tiveram sustentação nos estudos da Escola de Tártu-Moscou (VELHO, 2007; MACHADO, 2011; AMÉRICO, 2012).

Assim, a cultura passa a ter um conceito diverso do até então apresentado, ou seja, cultura é o conjunto de sistemas semióticos, que guarda a memória não-hereditária da coletividade de forma dinâmica, ou ainda, pode ser representada por um conjunto de relações de expressão - signicidade - e conteúdo - signo (LÓTMAN e USPENSKII, 1971). Esse conceito é diferente do conceito antropológico ou sociológico, apesar de serem inter-relacionados. O antropólogo GEERTZ (1989), por exemplo, define a cultura, resumidamente, como as teias de significados tecidas e amarradas aos homens e a sua análise. Essa definição se encontra com o da semiótica por enxergar o homem como o criador e transformador da cultura.

MORIN (2004), estudioso dos sistemas complexos, conceitua a cultura num enfoque antropológico: "uma cultura fornece os conhecimentos, valores, símbolos que orientam e guiam as vidas humanas", completando que, embora a cultura fosse para uma elite, deve ser vista como uma preparação para a vida de todos (p.48).

A cultura como dinâmica transformadora e processadora da informação trouxe novas ideias. Por fazer parte dessa cultura, interagir e participar das suas transformações, surgiu a possibilidade de usar o método semiótico de estudo para a sua interpretação.

Para experimentar o referencial teórico da semiótica da cultura, no sentido de buscar o novo, serão descritos, a seguir, os sistemas modelizantes envolvidos no ciclo da comunicação científica. Nessa experimentação, três disciplinas se entretecem: ciência da informação, saúde pública e semiótica da cultura. A semiótica será utilizada 
porque aprofunda a reflexão sobre comunicação, esta última interagindo com as três disciplinas (Figura 3).

Figura 3 - Diagrama representando a interseção das disciplinas, construído com base no modelo de Venn.

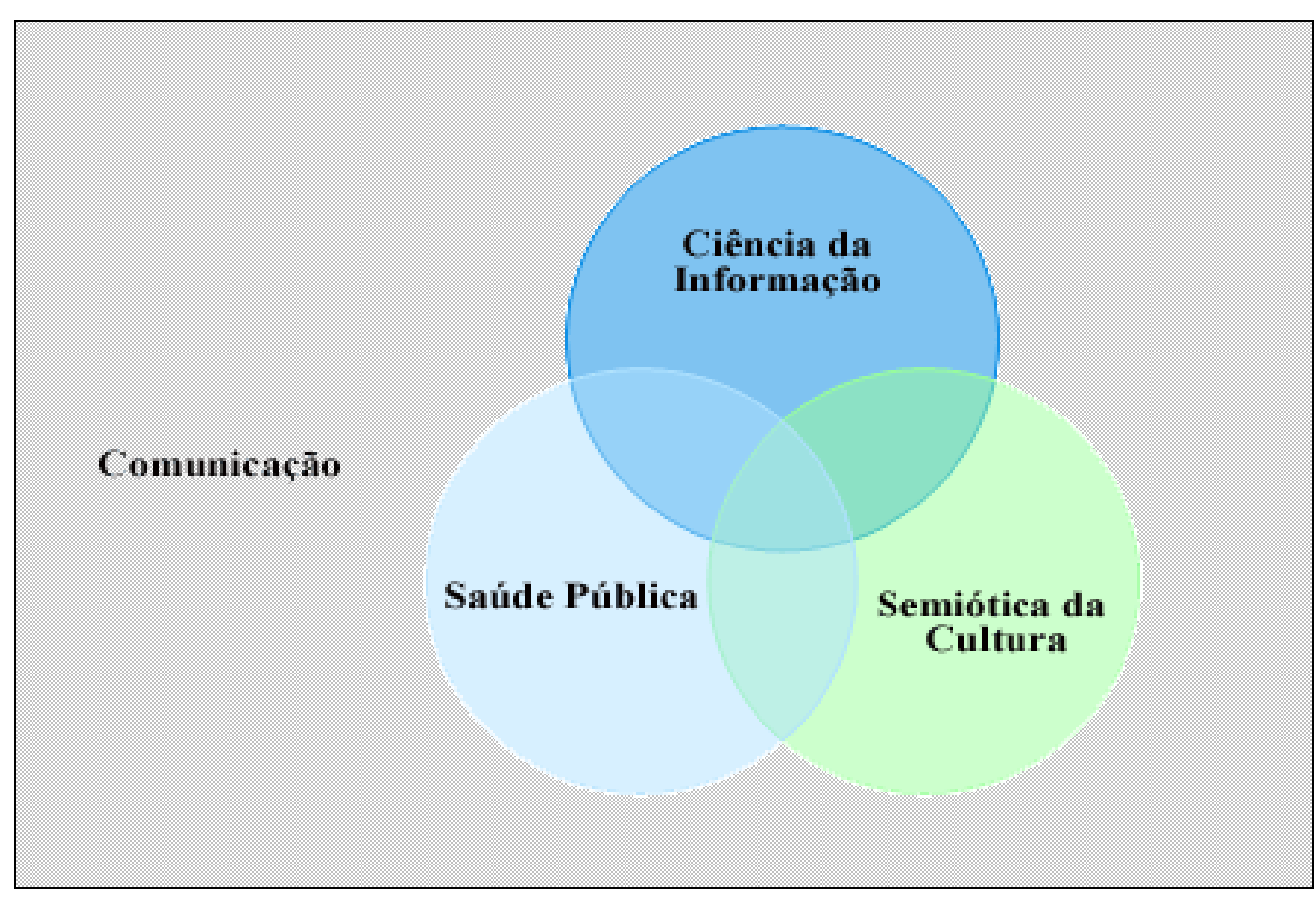

\subsubsection{Sistemas Modelizantes e Textos da Comunicação Científica}

Quais os sistemas modelizantes envolvidos na comunicação científica? Antes de tentar responder essa questão, faz-se necessário compreender alguns conceitos. Sistema modelizante é o eixo central da semiótica da cultura, são códigos da cultura estruturados hierarquicamente. O conjunto de códigos na cultura é transformado a partir dos diálogos entre elas. As novas informações que, a princípio, podem causar estranheza em dada cultura, com a repetição transformam-se qualitativamente, estruturando-se num modelo na cultura, uma espécie de algoritmo. Nas palavras de MACHADO: "modelizar, contudo, não é reproduzir modelos e sim estabelecer correlações a partir de alguns traços peculiares. Implica antes a adoção de uma espécie de algoritmo cujo resultado mostra que o objeto modelizado jamais resultará numa cópia” (2003a, p.50). 
Os textos na cultura podem ser criados com base nos sistemas modelizantes e podem criar modelos apoiados em determinados sistemas. A informação estruturada na cultura transforma o texto em linguagem para armazenar e criar a sua memória.

A linguagem e o sistema modelizante estão indissoluvelmente ligados. Como linguagem este trabalho se apoia na definição de LÓTMAN (1978): linguagem é todo sistema de comunicação que utiliza signos de modo particular. Linguagem é um sistema codificado na cultura.

O conceito de texto é bastante complexo e pode ser exemplificado como uma escultura, um quadro, um livro, uma música, um objeto industrial, uma dança, um trabalho acadêmico científico a até mesmo uma cultura ("texto no texto"). Um texto não precisa ser necessariamente lingüístico, é uma criação para significar, um gerador de sentido em processos interativos. A descoberta da possibilidade de um texto preceder a linguagem causa estranheza para os que defendem a idéia de alguns linguistas de que a linguagem é a matriz de todo texto. Entretanto, LÓTMAN (1996) argumenta essa possibilidade com o fato de ocorrerem manifestações culturais que podem ser observadas e percebidas mesmo sem um contato com a linguagem: "aqui devemos incluir um amplo círculo de fenômenos que se relacionam com os fragmentos das culturas arcaicas que têm chegado a nós, são muitos os casos em que a arqueologia dispõe de um objeto (=texto) cuja função, como o contexto cultural próprio dele, nos é desconhecida" (p.87).

Além desse exemplo, LÓTMAN comenta sobre obras da atualidade (esculturas, construções arquitetônicas) com linguagens desconhecidas e das crianças que entram em contato com textos antes de dominarem a linguagem. O texto é material para reconstruir a realidade e, por isso, deve ser analisado semioticamente antes da análise histórica (LÓTMAN e USPENSKII, 1981). Ao se analisar um poema, por exemplo, primeiramente temos que compreender o sentido, visualizar sua estrutura, interpretar as frases e palavras sem levar em consideração o referencial histórico, uma vez que o poema também é uma interpretação.

São vários os sistemas modelizantes envolvidos no processo de comunicação científica, desde a fase da busca em bases de dados bibliográficas até a escrita do texto científico. Para experimentar a teoria da semiótica da cultura no contexto deste trabalho, são levantados a seguir alguns sistemas modelizantes: a linguagem natural, a linguagem 
de busca dos programas de computação, a linguagem documentária e a estrutura do texto científico.

\subsubsection{Linguagem Natural}

A linguagem natural é o primeiro modelizador, é o idioma de domínio dos sujeitos envolvidos no processo de comunicação. O homem forma, desde a infância, uma ideia do mundo pelo prisma de sua língua materna. A língua influencia o pensamento, embora essa influência seja limitada e corrigida pela prática da vida (KONDRATOV, 1972). Sendo assim, a língua materna na comunicação científica é a base no processo de comunicação.

Os textos produzidos são codificados ao menos duas vezes: uma pela linguagem natural e outra pelo sistema modelizante de códigos das ciências. Portanto, os textos envolvidos na comunicação científica têm como base a linguagem natural, que é dinâmica por sua essência (LÓTMAN e USPENSKII, 1981). No espaço semiótico, a língua natural encontra-se no núcleo da cultura e se desenvolve mais lentamente que as outras estruturas ideológico-mentais.

Uma questão que pode ser observada no processo de comunicação científica, no caso brasileiro e de outros países, é a utilização de outro idioma para a elaboração de texto: o inglês. O idioma inglês é considerado a "língua franca da ciência", citação polêmica por envolver questões sobre o domínio cultural (FORATTINI, 1997). A cobrança pela utilização do idioma inglês é justificada para oferecer maior visibilidade da produção científica em todo o mundo, mas, por outro lado, oculta a influência de uma cultura sobre a outra, chamada, por FORATTINI, de "imperialismo científico" (p.5).

Entretanto, a existência de outro idioma para a semiótica da cultura parece não ser um problema. A justificativa é que, na tradução, o conteúdo mantém suas características, embora informações novas ocorram em cada uma delas por envolver mentes pensantes diferentes. Mais importante que esse argumento é que no idioma inglês a linguagem cumprirá seu papel ontológico da "hipótese de comunicabilidade" (LÓTMAN e USPENSKII, 1981. p.60), caso em dada cultura haja domínio da mesma, como no das ciências. 


\subsubsection{Linguagem de Busca dos Programas de Computação}

Outro sistema modelizante é a linguagem de busca dos programas utilizados para recuperação de informações em bases de dados. Trata-se de linguagem artificial, utilizando combinações lógicas (operadores boleanos), índices de palavras, ordenação, entre outras ferramentas, construídas com o objetivo de proporcionar a comunicação humano-máquina ou máquina-máquina. Ela caracteriza-se por não ser dinâmica como as linguagens naturais e sua transformação é controlada por seres humanos que a retroalimentam. Uma linguagem utilizada por bases de dados e programas de busca é a XLM (eXtensible Markup Language). O campo de estudo da inteligência artificial tem desenvolvido linguagens para os sistemas informáticos interagirem entre si. Os códigos são criados e identificados por outros sistemas artificialmente.

$\mathrm{Na}$ interação humano-máquina, ao utilizar o computador é necessário compreender desde as funções das teclas e equipamentos até as estruturas dos programas e arquitetura dos portais que serão usados. São muitas as linguagens envolvidas na busca de informação em bases de dados. Quanto melhor contato, melhor a busca e melhores resultados. Nessa esfera estão os códigos digitais e sistemas de diferentes linguagens (sons, imagens, ícones), que dão suporte ao diálogo universal e à diversidade de idiomas (MACHADO, 2003a). A interconectividade possibilita a aproximação de pessoas de diversas regiões do mundo.

A comunicação na era da informática é estabelecida de muitas formas, artificialmente entre os sistemas de máquinas, entre os humanos e as máquinas e entre os humanos intermediados pelas máquinas. Essas possibilidades estão complexificando as linguagens e códigos. A comunicação por meio de hipertextos, partilhados entre as pessoas, modificam a configuração da mensagem de acordo com a rede de relações pela qual ela é capturada (LÉVY, 1999). Hipertexto é um texto em formato digital, reconfigurável e fluido, composto por blocos elementares ligados entre si, que podem ser explorados em tempo real na tela. O hipertexto apresenta-se em categorias de signos, como imagens, sons, animações etc. (LÉVY, 1999).

Essa transformação na cultura, decorrente das novas tecnologias, é nomeada por LÉVY (1999) como cibercultura. Na cibercultura, a informação nas redes digitais encontra-se fisicamente situada em algum lugar e num determinado suporte, mas ela está virtualmente presente em cada ponto da rede onde é pedida. Isto ocorre com uma 
imagem ou um som, por exemplo, que passam por transformações de signos multiplicados indefinidamente. "O computador é, antes de mais nada, um operador de virtualização da informação" (LÉVY, 1999; p.55).

O desenvolvimento de sistemas, que permitem a inserção de dados por qualquer pessoa que faça buscas ou digite palavras nos grandes provedores da internet, possibilita a formação de um grande armazenamento de dados, conhecido como big data ou megadados em português. LÉVY" (2014) chama de "mídia algorítmica" a ubiquidade da informação (está em toda a parte e em todo o tempo), a interconexão entre as pessoas e documentos e a capacidade de manipular símbolos automaticamente. Um texto inserido na internet pode ser reunido a outros quando se faz uma pesquisa no Google, por exemplo, formando e transformando um grande documento.

Essa nova forma de pensar a busca como formadora de um grande texto ainda está se desenvolvendo, sendo difícil prever o que ocorrerá com as próximas gerações. LÉVY* exemplifica com a situação de uma compra de livro na Amazon: quando alguém digita uma busca e compra um livro, as definições de sugestões para pessoas que tem gosto parecido com o comprador são alteradas, mudando as relações entre os dados e a memória comum dos usuários. LÉVY" enfatiza que "não percebemos, mas a cada hora que fazemos algo online, acionamos algoritmos. Estamos programando a memória digital, mesmo não sabendo. Estamos, o tempo todo, classificando coisas no Twitter, por exemplo, pelo hashtag, como antigamente somente bibliotecários faziam ao catalogar livros".

Assim, essa linguagem da informática, que parece a princípio pouco dinâmica, mostra-se mais transformadora do que se pensa e gera novos textos a todo o momento. A tela do computador gera signos, como concluiu SANTAELLA (2004) e o ciberespaço tem sido estudado, pelas suas implicações culturais e sociais, a partir da década de 1990 (LÉVY, 1999). Esses estudos estão longe de ser conclusivos.

\footnotetext{
* Lévy P. Ciberdemocracia hoje [palestra proferida no SENAC, São Paulo, 2014]
} 


\subsubsection{Linguagem Documentária: Tesauro ou Vocabulário Controlado}

Outra linguagem artificial envolvida na recuperação da informação científica é a linguagem documentária. Trata-se de um sistema modelizante, representado pelos vocabulários controlados de descritores, assim chamados em ciência da informação. As áreas do conhecimento, a partir de seus assuntos especializados, criaram listas hierárquicas de termos, relacionados entre si, com a finalidade de facilitar a comunicação. Ao contrário de uma palavra, que promove a diversidade interpretativa, os vocabulários controlados unificam os conceitos dos termos para auxiliar na indexação e recuperação da informação. Em alguns aspectos, considera-se esse sistema modelizante um paradoxo na comunicação por limitar as possibilidades de interpretações ou efetivação ampla da comunicação. Entretanto, essa linguagem artificial igualmente se modifica, mesmo que de modo controlado.

A linguagem documentária, diferente da linguagem natural, caracteriza-se por ser estática, ter regras específicas e próprias, baixo poder combinatório, significados controlados e função referencial ou de metalinguística (VOGEL, 2007). Estudos sobre o conceito de linguagem documentária estão em discussão na ciência da informação, tais como: a representação do conhecimento para tratar a informação para recuperação, a fonte para interpretação de sentido, as questões de metalinguagem e as relações com a terminologia (CUNHA, 1990; LARA, 1999, 2002; TÁLAMO e col., 1992; TÁLAMO, 1997, 2004).

Tesauro é uma linguagem artificial, construída a partir da linguagem natural como um todo, e que tem por referência a terminologia no processo de representação. Entende-se por linguagem um elemento que nos permite pensar o mundo, conhecer e comunicar, criando elos simbólicos (LOPES, 1987). Na linguagem natural uma cadeia de signos pode ter diversos significados, que na linguagem artificial, apesar de adquirir complexidade, fecha-se num único significado. O texto artificial numa linguagem artificial é o mecanismo extremo para cumprir a função de "transmissão adequada de significados" (LÓTMAN, 1996, p.94). O tesauro envolve, em grande parte no seu processo de construção, a linguagem científica.

O tesauro registra e representa o conhecimento de uma área, aqui entendida como uma cultura. A palavra tesauro tem origem greco-latina e significa tesouro, depósito de conhecimento, coleção de termos, lista de descritores ou termos de 
indexação. Caracteriza-se pelas relações associativas, hierárquicas e de equivalência entre os termos com apoio na linguagem de especialidade (CURRÁS, 2010). É um vocabulário controlado e estruturado, construído com base na terminologia de uma área especializada do conhecimento. Ele organiza estruturas lógicas de categorias e conceitos no domínio, assim como as relações semânticas entre os conceitos. A estrutura, segundo um léxico hierarquizado, compõe-se de termos, chamados descritores, os quais contribuem para representação de conceitos.

O tesauro converte conceitos e suas relações, expressas em linguagem natural, para uma linguagem controlada, evidenciando que a informação tem sua existência atrelada aos sistemas de significação. Assim, precisa ser utilizado no âmbito desse universo de sistemas para a identificação, análise, tratamento e disseminação da informação. Os tesauros são construídos com base na narrativa dos pesquisadores, garantindo assim sua atualização e sua representação expressa em textos científicos, constituindo um todo significativo (LIMA, 2007).

O objeto do tesauro constitui-se das relações lógico-semânticas, pois as relações sintáticas são formadas na:

- indexação, a partir de documentos (textos), e

- recuperação (elaboração das estratégias de busca), a partir do tesauro, que pode estar explícito ou implícito (figura 4).

Figura 4 - Diagrama representando os processos de indexação e recuperação da informação usando o tesauro.

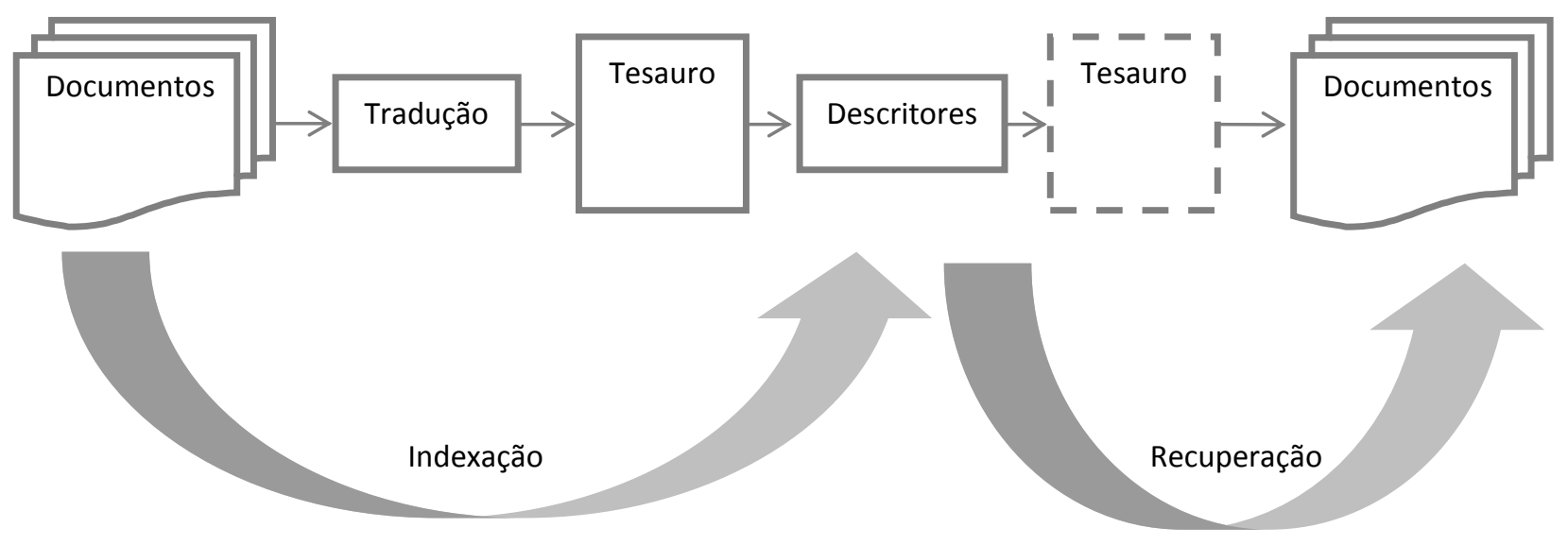

O tesauro é construído num eixo paradigmático, ou seja, cada termo tem um sentido fechado com base num sistema modelizante, numa possibilidade. Na ocasião da 
recuperação da informação, o sujeito elabora, mentalmente, uma ordem sintática para estabelecer as relações entre os termos e só então faz a seleção daqueles que vão compor sua estratégia de busca. Um exemplo dessa situação é um pesquisador construindo uma estratégia de busca em bases bibliográficas para o enunciado: "incidência da aids em crianças órfãs". Esse enunciado faz parte do plano sintagmático (ordem). Ao preparar a estratégia de busca, os termos se decompõem e ficam estabelecidos: "epidemiologia" (inclui o conceito de incidência), "aids" (doença síndrome da imunodeficiência adquirida), "crianças" (humanos na faixa etária de 0 a 12 anos), "orfandade" (situação social de filhos cujos pais faleceram). A combinação desses termos com os operadores lógicos boleanos forma a sintaxe da estratégia de busca.

Os descritores do tesauro compõem-se do núcleo sêmico dos termos, o conteúdo positivo e invariável de um lexema (Greimas, citado por LOPES, 1987). Um mesmo descritor pode ter significados diferentes, dependendo do contexto a que pertence, mas todo descritor carrega em si um traço semântico fixo, peculiar. Retomando o exemplo anterior, a palavra aids pode ser vista como uma sigla com outros significados além da doença e pode também ser uma palavra traduzida do inglês como subsídios, porém no contexto do tesauro de saúde essa palavra traz consigo o traço semântico de uma doença, seu núcleo sêmico.

\subsubsection{Terminologia na Área da Saúde Pública}

Com base na teoria da semiótica da cultura, as funções do texto são comunicativa, criativa e de memória (LÓTMAN, 2000). Portanto, o tesauro de uma área específica tem por funções facilitar a comunicação, gerar sentido e novas ideias a partir dos enunciados de busca, além de preservar o registro da terminologia da área.

Entende-se por terminologia uma linguagem de especialidade, um processo, parte da língua natural, um conjunto de termos de uma área específica gerado pela prática, fonte de interpretação de conceitos e significados (BARROS, 2004; CABRÉ, 1999). Uma disciplina consolida-se quando impõe seus conceitos através de sua denominação (BENVENISTE, 1991), logo, a terminologia é inerente à cultura acadêmica especializada e suas comunicações técnico-científicas (artigos 
especializados, livros didáticos, teses, manuais, resenhas), garantindo, assim, o seu domínio e constituindo-se como disciplina. Terminologia pode ser definida como uma disciplina centrada num objeto (as unidades terminológicas), levando em conta as áreas do conhecimento e os contextos em que aparecem (CABRÉ, 2005; SAGER, 1993).

$\mathrm{Na}$ área da área da Ciência da Informação, a terminologia fornece princípios metodológicos para a identificação de conceitos e suas designações e para o estabelecimento de relações entre eles, fornecendo referências concretas para o entendimento desses conceitos por meio de instrumentos terminológicos, como dicionários e glossários técnico-científicos. Para a linguagem documentária, a terminologia é o instrumento que busca a produção de sentido num contexto para representá-lo na informação documentária (LIMA, 2004).

Na área da Saúde Pública, a terminologia vem sendo construída a partir das publicações científicas, principalmente dos artigos nos periódicos, da grande área da saúde. Alguns deles, como Lancet, Nature, Science, expoentes da divulgação científica internacional, foram lançados nos séculos XIX e XX e são correntes até hoje. No decorrer do tempo, os periódicos foram se expandindo e se especializando, caracterizando a "explosão bibliográfica" observada após as grandes guerras (MEADOWS, 1999). Mais recentemente, as tecnologias de informação e comunicação ampliaram ainda mais as fontes para a formação da terminologia. LE COADIC (1996) comenta que o crescimento da literatura científica obedece a uma lei exponencial e o volume de informação nos faz "duvidar da cordialidade da nova sociedade da informação" (p.7).

Tradicionalmente, na área da saúde, a alta aplicabilidade dos resultados de pesquisas demanda rapidez na divulgação das informações e, como consequência, sua terminologia se desenvolve constante e rapidamente. Dois vocabulários destacam-se: o tesauro Descritores em Ciência da Saúde (DeCS), mais usado em países da América Latina, e o Medical Subject Headings (MeSH), com maior divulgação internacional. O DeCS (Figura 5) é um vocabulário estruturado, trilíngue, criado pela Bireme para servir como linguagem única na indexação e recuperação de artigos para a base Lilacs e bibliotecas virtuais, com abrangência na América Latina*. O DeCS foi desenvolvido

\footnotetext{
* Informações disponíveis no site: http://decs.bvs.br/P/decsweb2012.htm
} 
com base no MeSH, da U.S. National Library of Medicine, que será detalhado a seguir por ser um modelo.

Figura 5 - Página para acesso ao DeCS pela internet, 2014

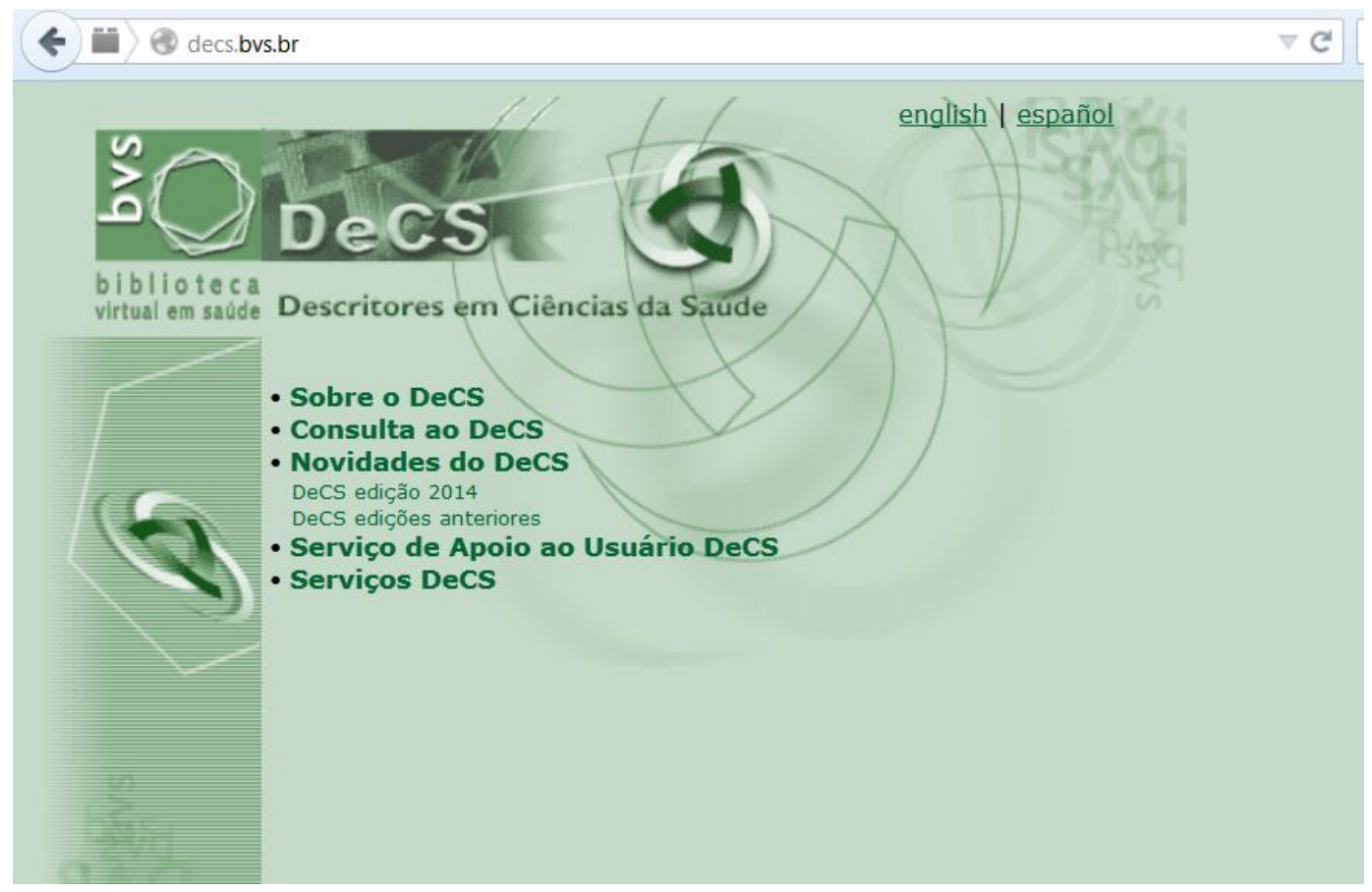

O tesauro $\mathrm{MeSH}^{*}$ é o vocabulário controlado da National Library of Medicine (NLM), composto por um conjunto de termos, os descritores, distribuídos numa estrutura hierárquica que permite busca em vários níveis de especificidade. Seus 26.142 descritores estão arranjados também alfabeticamente, além da estrutura hierárquica que os relacionam entre si. Periodicamente, a equipe de especialistas da NLM atualiza o MeSH com a inserção ou modificação dos descritores, contando com a colaboração de pesquisadores e autores por meio de sugestões (NELSON, 2011).

Apesar de trazer no nome a designação de cabeçalho (headings), remetendo às antigas listas de cabeçalhos de assuntos, o MeSH, pelas suas características atuais, pode ser considerado um tesauro. O nome Headings foi mantido no decorrer do tempo, como veremos no breve histórico mais à frente. A palavra mesh em inglês também traz consigo o significado de malha, entrosamento, estrutura entrelaçada, enredada. $\mathrm{Na}$ Informática, mesh quer dizer malha, ou qualquer sistema com dois ou mais caminhos em cada interconexão (MICHAELIS, 2005).

\footnotetext{
*Disponível em http://www.nlm.nih.gov/mesh/intro_hist2006.html
} 
Outra observação sobre o MeSH é o grande número de descritores, muito maior que o comumente utilizado nos tesauros. Essa particularidade ocorre devido à quantidade de termos que se acumularam desde seu início, em 1954, com desenvolvimento da ciência.

$\mathrm{O} \mathrm{MeSH}$ é usado principalmente para indexar as revistas da área biomédica selecionadas para a base MEDLINE/PubMed (5400 títulos) e pode ser consultado eletronicamente no site http://www.nlm.nih.gov/mesh.

A divulgação do MeSH era feita em volumes anuais impressos e acompanhavam a assinatura do Index Medicus. Com a popularização dos microcomputadores nas universidades passou a ser comercializado no suporte de CD Rom nas décadas de 1980 e 1990. Isso veio a facilitar sobremaneira a sua utilização, por permitir a combinação automática de termos e a sincronização direta com a base MEDLINE. Com o advento da internet, o MeSH passou a ficar disponível para consulta online com a característica de uma base de dados e interligado à base de dados MEDLINE. A interface de busca é frequentemente atualizada, buscando a usabilidade e uma construção centrada no usuário. Isso coloca em discussão, segundo ESTRADA (2011), se o tesauro MeSH está evoluindo e tornando-se um topic map, um modelo normalizado de sintaxes de intercâmbio para representar produtos e integrar conceitos em ambientes digitais em conformidade com a organização do conhecimento.

A página do MeSH na internet apresenta uma foto com a imagem de árvores, sendo que sua logomarca também é a imagem de uma árvore (Figuras 6 e 7). Isso representa a estrutura do tesauro com base na estrutura semântica. Cada grande galho da árvore corresponde a uma categoria da saúde e cada um desses galhos se ramificam em termos subordinados tematicamente aos principais. Dessa forma o símbolo escolhido, árvore, remete ao conceito teórico usado para construção do tesauro. 
Figura 6 - Página para acesso ao MeSH pela internet, 2011.

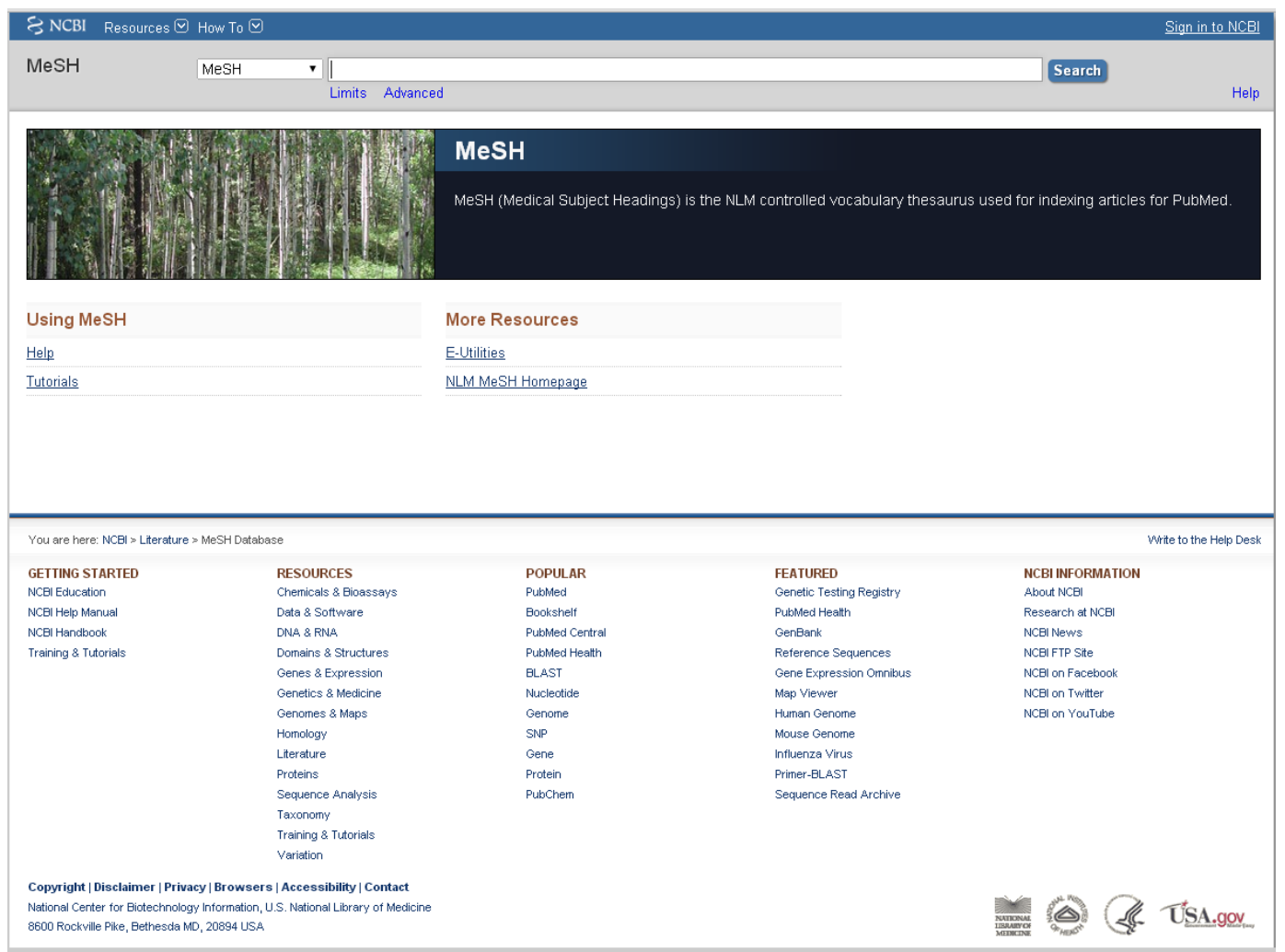

Fonte: NLM

Figura 7 - Logomarca do Tesauro MeSH, 2011.

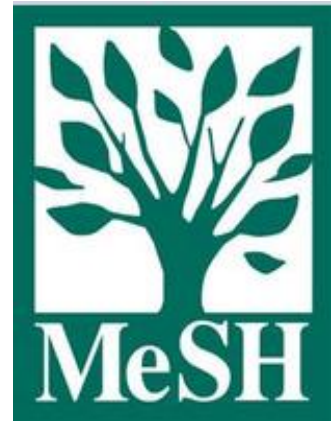

Fonte: NLM

A descrição apresentada, com o apoio da literatura sobre linguagens documentárias, permite-nos concluir que o tesauro MeSH é bastante completo e segue padrões de qualidade. Ele é elogiado por cientistas da computação, como Jim Gray (HEY e col., 2011). Entretanto, não podemos inferir se ele é útil para o usuário e atende o âmago da sua função, que é comunicativa, sem considerar a percepção desse sujeito e a complexidade na área da saúde, que encerra várias dimensões e abordagens, como as questões que envolvem o tema HIV/aids. 


\subsubsection{A Estrutura do Texto Científico}

Há que se destacar também o sistema modelizante envolvido no processo da escrita científica, especificamente no artigo de periódico, veículo de maior divulgação da ciência na área da saúde e que tem uma estrutura ideológico-mental. Pesquisadores exploram, há muito tempo, a melhor forma de divulgar seus resultados de pesquisas, em padrões, para simplificar a comunicação de seus achados.

Um modelo clássico, amplamente utilizado na ciência, é o IMRD (Introdução, Método, Resultado e Discussão). Esse formato é considerado prático e eficaz, para divulgação das pesquisas científicas, por colocar o conteúdo numa sequência lógica para o leitor potencial (MEADOWS, 1999; REY, 1993). Porém, esse formato não é unânime entre os pesquisadores, principalmente das áreas de Humanidades e Exatas. Para SANCHES (2009), o modelo IMRD não pode ser visto como uma "camisa de força", pois, está sujeito a alterações em função da área do saber em que se inscreve. Trata-se de um sistema modelizante mais periférico na cultura das humanidades e, por isso, mais sujeito a transformações.

As instituições acadêmicas e revistas científicas utilizam modelos próprios de apresentação de trabalhos, geralmente especificados em textos escritos, como manuais para escrita e orientações aos autores. Noutras situações esses modelos surgem implicitamente nos trabalhos armazenados e/ou publicados, indicando o padrão da maioria. A comunicação oral entre pesquisadores também colabora para a disseminação de modelos institucionais.

O estilo acadêmico e a estrutura dos textos podem facilitar ou dificultar a comunicação das pesquisas científicas. Para MEADOWS, 1999, "quanto mais amplamente aceita for a estrutura na qual o pesquisador escreve, mais facilmente outros pesquisadores poderão absorver a informação transmitida" (p.174). Entretanto, a diversidade de estilos e estruturas nas grandes áreas do conhecimento pode gerar conflitos na escrita de textos multidisciplinares, interdisciplinares e transdisciplinares. 


\section{A CONSTRUÇÃO DO OBJETO E AS RELAÇÕES COMUNICAÇÃO E SEMIOSFERA}

Para se estudar a comunicação científica sob a teoria da semiótica da cultura, além de descrever os sistemas modelizantes e seus textos, é necessário analisar a interação entre eles.

A comunicação que se processa entre os sujeitos da cultura representa o sentido e a memória. Pela comunicação conjugam-se novos signos na cultura, sendo interessante desvendar quais são os novos sistemas modelizantes que se formam e as modelizações que se seguem. Para LÓTMAN (1978), cada linguagem é um sistema de comunicação e um sistema modelizante, "essas duas funções estão indissoluvelmente ligadas" (p.44).

A comunicação pertence à natureza e à cultura. É pela comunicação que se mantém a ordem, diminui a entropia, transmite influência de um sistema vivente para outro e produz mudança (SEBEOK, 1997). Os sistemas de comunicação são dinâmicos e adaptativos, servindo tanto para o contexto externo quanto para o interno, segundo SEBEOK (1997). Nesse caso, o estudo passa a ser também um estudo do "texto no texto", ou seja, o texto não se encerra em si mesmo, mas se amplia com o contexto. Assim, é necessário complementar o presente estudo, experimentando e buscando como a cultura está se interpretando; em outras palavras, estudar o diálogo da cultura.

Como visto nos capítulos anteriores, no cenário acadêmico, o pesquisador encontra novas maneiras de fazer suas buscas, visando mais rapidez na atualização das informações no contexto da sua pesquisa. Na prática bibliotecária, observa-se que os pesquisadores desconsideram importantes ferramentas de busca oferecidas pelos sistemas de informação e bibliotecas (CUENCA, 1999). Observam-se entraves na comunicação entre profissionais da informação e pesquisadores por questões culturais, refletindo na qualidade da recuperação da informação mediada pelo bibliotecário.

A semiótica da cultura pode ajudar a compreender os processos de transformação, tanto da informação em texto (modelização de seus códigos e linguagens), quanto da dinâmica do texto com o contexto, o ambiente interpretativo. $\mathrm{O}$ contexto ajuda a decodificar a mensagem e a recodificá-la. 
Dependendo do contexto, os signos são interpretados diferentemente. Uma dada cultura pode ser representada, também, como um contexto onde se processa a comunicação ou semiose (intercâmbio de mensagens).

A semiose da informação e comunicação é um tema semiótico que leva em conta o contexto do pensamento evolutivo na perspectiva sistêmica. O contexto é o ambiente da interpretação da comunicação e inclui uma gama de sistemas cognitivos. O contexto pode ser crucial para resolver a significância da mensagem e pode causar a desconsideração da forma e do conteúdo na comunicação (SEBEOK, 1997).

Quando se fala de texto no contexto e semiose na cultura, estamos desenvolvendo o conceito de semiosfera. LÓTMAN (1996) comentou sobre o perigo de se estudar isoladamente os sistemas, porque o funcionamento dos mesmos está submerso num continuum semiótico, que o levou a chamar de semiosfera, por analogia ao conceito de biosfera de Vernadski. "Disposta sobre a superfície do nosso planeta e abarcadora de todo o conjunto da matéria viva, a biosfera transforma a energia radiante do sol em energia química e física, dirigida, por sua vez, à transformação da 'conservadora' matéria inerte do nosso planeta" (LÓTMAN, 1996, p.22).

A semiosfera ou espaço semiótico é o objeto de estudo da semiótica, uma metaciência, que procura descrever as relações dos sistemas de signos ou descrever um conjunto de distintos textos e linguagens, fechados uns em relação aos outros. A semiosfera pode ser definida como uma rede processual de semioses, a esfera da comunicação na cultura. A cultura gera estruturalidade pelos processos modelizantes e suas relações com o homem formam a semiosfera.

A semiosfera pode ser, além de um objeto de estudo, um método para estudar a cultura, a "semiosfera é estudada por meio da semiosfera", como colocou TOROP (2007, p.50), "um diálogo entre o objeto de pesquisa e a linguagem que o descreve". Sendo assim, o objeto comunicação científica pode ser estudado na semiosfera e, ao mesmo tempo, ser o método para seu próprio estudo, quando há uma reflexão de seus próprios sujeitos.

Devido à complexidade primordial de se estudar a semiosfera na semiosfera, faz-se conveniente delimitar as fronteiras do espaço semiótico e conhecer suas características teóricas. 


\section{Características teóricas da semiosfera}

Dentre as características teóricas da semiosfera destaca-se o seu caráter delimitado (LÓTMAN, 1996). Entender a semiosfera implica em traduzir os textos e linguagens que estão na fronteira, em interação com o externo aos seus limites. A fronteira da semiosfera tem como função controlar, filtrar e adaptar o externo no interno. Nas palavras de LÓTMAN: “a fronteira é um mecanismo bilíngue que traduz as mensagens externas para a linguagem interna da semiosfera e vice-versa" (1996, p.26). Como um grupo de pesquisadores traduz a comunicação científica e interpreta as linguagens externas? Como o grupo se auto-define culturalmente e traça a fronteira comunicacional entre si (sujeitos) como processo de construção do outro (não pertencente ao grupo)? A transmissão da informação, cruzando as fronteiras internas orientadas pelas estruturas semióticas, gera sentido e promove o surgimento de informações novas. Assim, se produzir informação nova é o objetivo do grupo de pesquisa, podemos inferir que o grupo precisa ter contato com outras linguagens e traduzi-las para dar sentido à sua existência como grupo de pesquisa.

Para exemplificar essa característica retoma-se a questão da terminologia: um grupo de estudos formado por médicos, com sua terminologia própria, ao comunicar-se com os pacientes, precisam transformar essa terminologia em outra linguagem para tornar possível a comunicação. Dessa forma, pode fazer desenhos ou apresentar bonecos para explicar sobre os efeitos de determinada doença no organismo. Nesse exemplo, a possibilidade de traduzir a linguagem garante a existência da outra.

Outro exemplo é a padronização de linguagem e delimitação de sentidos dos vocabulários controlados. As bibliotecas, ao utilizarem instrumentos de representação e recuperação da informação, criam uma linguagem artificial para atender ao coletivo inteligente.

A segunda característica teórica a ser destacada da semiosfera é sua irregularidade semiótica. Aquilo que do ponto de vista interno de uma dada cultura, o observador vê como o mundo não semiótico externo, "da posição de um observador externo pode apresentar-se como periferia semiótica da mesma. Assim, da posição do observador depende por onde passa a fronteira de uma dada cultura" (LÓTMAN, 1996, p.29). No núcleo da semiosfera estão os sistemas semióticos dominantes e, na periferia, as transformações. $O$ encontro dialógico na semiosfera permite demonstrar a 
irregularidade dos textos em constante movimentação. Sistemas de signos, que num momento histórico são centrais, podem se tornar periféricos em outros momentos. Daí a questão de como o grupo de pesquisadores convive com a diversidade de modelizações de linguagens em estudos inovadores, que buscam transcender as fronteiras disciplinares diante dos problemas complexos (ALVARENGA e col., 2015)

Outra característica da semiosfera é a simetria e assimetria. O diálogo entranha a reciprocidade e a mutualidade no intercâmbio de informação, desde as conexões dos hemisférios cerebrais até o intercâmbio entre culturas e, por isso, pode-se dizer que o diálogo precede a linguagem e a gera (LÓTMAN, 2000). Como no cérebro humano, no qual há uma interconexão entre os hemisférios direito e esquerdo, na semiosfera as informações novas emergem no espaço das relações assimétricas. Há um paralelo entre cérebro e cultura: por um lado os signos são interpretados mediante correlações com outras semiosis (racional, inteligível) e, por outro, há uma tendência a fechar-se num mundo semiótico plano e isolado (irracional). No cérebro da cultura há momentos de estabilidade e de desestabilidade, num contínuo diálogo. A interconexão dos elementos na semiosfera é uma realidade. O grupo de pesquisadores é um coletivo inteligente nos momentos em que se posicionam como unidade, ou uma "persona coletiva", termo usado por LÓTMAN (1996, p.25). A inteligência coletiva manifesta-se na capacidade de transmissão de informação, geração de informação nova e memória.

A imprevisibilidade na semiosfera contribui para a geração de informação nova. Em alguns momentos, na situação semiótica, ocorre o fenômeno da explosão, que são ações e interações dentro da semiosfera que desenvolvem aceleradamente os sistemas modelizantes. Esse fenômeno não destrói a cultura, mas extravasa os limites e interrompe a cadeia causal previsível, levando à imprevisibilidade e a um aumento da informação (LÓTMAN, 1999). A ampla interconectividade possibilitada pela internet pode ter ocasionado uma grande quantidade de informações novas na semiosfera.

Como se observa, a comunicação na semiosfera deve ser pensada não somente como transmissão de mensagens de um emissor a um receptor. Na semiosfera os sistemas de linguagem são complexos, incluindo as línguas naturais, artificiais e os sistemas modelizantes da cultura. Todo esse processo deve ser descrito e analisado para contextualizar a comunicação.

Somente analiticamente podemos isolar a estrutura semiótica, como um texto, por exemplo, porque, na realidade, ela só pode funcionar em condições de impulsos 
externos e internos pelo intercâmbio de textos na semiosfera. Isso gera um problema epistemológico neste estudo: como explorar a semiosfera (comunicação científica) na semiosfera? Algumas soluções podem ser encontradas nos diálogos dos sujeitos da cultura.

Nesse sentido, vale mencionar o fato de Hipócrates, considerado por historiadores médicos como o mestre da semiótica, fazer diagnósticos buscando distinguir, por um lado, as mensagens naturais ou signos objetivos (sintomas, marcas, sinais vitais) e, por outro lado, as mensagens convencionais ou signos subjetivos, resultantes da entrevista com o paciente somado à experiência profissional (SEBEOK, 1997). As "palavras faladas" variam de acordo com os símbolos e são traduzidas pelo médico, que juntamente com os sintomas e sinais "expressos pelo corpo" faz o diagnóstico da doença (LANA, 2004, p.272). Diante disso, é importante considerar as narrativas dos pesquisadores.

Assim, no presente trabalho parte-se do pressuposto que as "palavras faladas" pelos pesquisadores aos interlocutores, num diálogo, expressam o entendimento e as transformações que se processam na cultura acadêmica, de determinada área e segmento, na busca pela informação científica relevante.

A delimitação do espaço semiótico torna-se necessária para servir como ponto de partida no desenvolvimento deste estudo. Nessa perspectiva, sabendo que todo texto tem um sujeito, estudar os textos das entrevistas será interpretar os textos da cultura de determinada comunidade de pesquisa científica. Neste caso, pesquisadores pertencentes a grupos de estudo sobre aids, sujeitos desta pesquisa.

Os textos gerados do diálogo dos pesquisadores com os interlocutores formam um corpus congruente na cultura, revelando informação nova. É apropriado estudar o criado no dado nas relações discursivas da comunicação (BAKHTIN, 1982). Neste estudo, o dado será o corpus ou texto das entrevistas, onde está presente o criado (informações dos entrevistados, o significante). Há a interferência de uma terceira entidade, que, neste contexto, é a percepção de quem irá estudar os textos. Dessa interação são esperadas outras transformações desses mesmos textos (interpretante).

No âmbito da semiosfera sujeito e objeto estão em constante relação dialógica, uma vez que o pesquisador-sujeito interpreta o texto-objeto, que é o resultado do diálogo da entrevista (entrevistador-entrevistado). 


\section{OBJETIVOS}

\subsection{OBJETIVO GERAL}

Analisar os textos, produzidos a partir das narrativas, de pesquisadores em HIV/aids sobre as estratégias de busca de informação técnica e científica nos sistemas bibliográficos de informação, na perspectiva da semiótica da cultura.

\subsection{OBJETIVOS ESPECÍFICOS}

1) Identificar os sistemas de signos centrais na semiosfera da cultura de pesquisadores.

2) Descrever as interações dos pesquisadores com sistemas de informação e bibliotecas.

3) Refletir sobre a comunicação e seus desafios na contemporaneidade 


\section{PROCEDIMENTOS METODOLÓGICOS}

A semiótica da cultura orienta a análise desta tese. Como já enunciado, essa teoria foi desenvolvida por semioticistas da Escola de Tártu-Moscou e teve como expoente Iuri Lótman, então professor de literatura russa na Universidade de Tártu, Estônia (MACHADO, 2003b). Para a semiótica da cultura, o sistema semiótico resulta de uma construção estruturada a partir de diferentes processos de codificação.

O método semiótico-estrutural é um procedimento de análise de caráter empírico com foco na descrição e síntese como entendimento. A finalidade do método é compreender a dinâmica das transformações nos sistemas de signos variados e linguagens modelizadas (MACHADO, 2013b).

Esse método procura estudar os elementos invariáveis, que constituem a estrutura dos sistemas, no contexto das variações. O observador introduz a dialogia no modelo para estudar a complexidade dos sistemas semióticos (MACHADO, 2013b). Assim, as interpretações, também chamadas traduções, serão feitas pela autora desta tese com a finalidade de descrever um modelo dialógico.

Para LÓTMAN (1998, p.95), “a linguagem da descrição não está separada da linguagem da cultura e da sociedade a que o pesquisador encontra-se filiado", portanto, a metalinguagem define o método semiótico e sua complexidade.

O objeto é complexo, sobretudo por usar a metalinguagem. Embora o desafio seja grande, exigindo um aprofundamento e interação do sujeito com o objeto como participantes da cultura, é possível apoiar-se na possibilidade de desvendar novas linguagens e melhor aproveitar o fluxo de informação. Como disse LÓTMAN (1978), o homem é o agente que transforma a informação em linguagem para que ela não se perca na cultura e, quanto mais linguagens houver, melhor aproveitaremos o fluxo da informação.

Outro desafio é contemplar com a interdisciplinaridade ou transdisciplinaridade e tentar estudar um objeto com as vertentes da ciência da informação, saúde, semiótica e outras disciplinas a elas relacionadas. Um trabalho interdisciplinar busca transpor fronteiras disciplinares e promover trocas na construção e interpretação do objeto (ALVARENGA e col, 2011). Lótman e Bakhtin reconhecem que o texto é um objeto transdisciplinar primário e unidade significante do tecido cultural. A diferença, grosso modo, é que para Lótman o interesse é pela funcionalidade do texto no interior de um 
sistema dinâmico e para Bakhtin, o texto expressa a "consciência ativa do homem social e histórico" (ARAN, 2007, p. 151). Nesse caso, também encontramos apoio em LÓTMAN (1978, p.50), quando afirma:

A transcodificação de uma linguagem noutra, extremamente produtiva na maioria dos casos e que surge em ligação com os problemas interdisciplinares, descobre num único objeto, tal como parecia antes, os objetos de duas ciências ou leva à elaboração de um novo domínio do conhecimento e de uma nova metalinguagem que lhe é própria.

A comunicação entre as disciplinas é complexa porque existem universos semióticos diferentes envolvidos nesse processo, mas essa diferenciação é importante para promover a inteligência e a memória coletivas porque abre o canal para o diálogo. Como disse LÓTMAN sobre o confronto entre arte e ciência, tão estudadas por ele pelo potencial criativo de ambas: "quanto mais a arte for arte e a ciência ciência, tanto mais específicas serão suas funções culturais e tanto mais o diálogo entre elas será possível e fecundo" (1981, p.28). Imitando esse autor, é importante que as áreas da saúde e da ciência da informação defendam seus princípios e pontos de vista para que o diálogo tenha uma razão para acontecer.

\subsection{A ESCOLHA DA TEMÁTICA E DOS PESQUISADORES}

A escolha da temática "aids" foi definida por representar uma doença com dinâmica diferenciada na área da saúde, como visto na introdução deste trabalho. Além da quantidade de trabalhos na literatura científica, há uma ampla divulgação de trabalhos sobre o tema em congressos, onde pesquisadores se agrupam para melhor estudar esse complexo tema.

Os pesquisadores são integrantes dos grupos de pesquisa Núcleo de Estudos para Prevenção da Aids (NEPAIDS), sediado em São Paulo, e Laboratório de Informação em Saúde (LIS) do Instituto de Comunicação e Informação Científica e Tecnológica da Fundação Oswaldo Cruz (ICICT/Fiocruz), com sede no Rio de Janeiro. A escolha dos pesquisadores foi feita por ocasião do desenvolvimento do trabalho de pesquisa, citado no próximo capítulo. 


\subsection{TRABALHO DE CAMPO E ENTREVISTAS}

Os dados foram coletados para a pesquisa "Transformações na comunicação científica: identificando necessidades e experimentando tecnologias com grupos de pesquisadores em HIV/aids", projeto elaborado por um grupo de pesquisadores da Faculdade de Saúde Pública da USP e da Fundação Oswaldo Cruz e coordenação geral do Prof. Dr. Ivan França Junior. Esse projeto foi aprovado pela FAPESP e esteve em vigência de agosto de 2008 a agosto de 2010.

Nesse projeto foram utilizadas três ferramentas para coleta de dados:

- Entrevistas semiestruturadas para recuperar a dimensão subjetiva das experiências individuais estudadas (DENZIN e LINCOLN, 2000);

- Grupo focal para levantar expectativas, ideias e perspectivas do grupo (CARLINI-COTRIM, 1996).

- Simulação em computador de busca em bases bibliográficas, para identificar como os pesquisadores efetivamente buscam as informações, quais são as bases consultadas, as estratégias e as sintaxes construídas e o manejo eletrônico dos resumos localizados.

Foi utilizada nesta tese somente a técnica de entrevistas semiestruturadas com dois grupos de pesquisa: um de São Paulo e um do Rio de Janeiro. Essa técnica foi escolhida com a intenção de levantar as percepções dos pesquisadores sobre como buscam e utilizam as informações científicas e as interferências das novas tecnologias nesse processo.

Foi elaborado um roteiro com questões para orientar as entrevistas, que passou por modificações conforme o ritmo e interação entre entrevistadora e entrevistado (Anexo). As entrevistadoras foram orientadas a deixar os entrevistados à vontade e a interagirem e dialogarem com eles. A autora deste trabalho participou das entrevistas efetuadas com o grupo de São Paulo. Para o grupo do Rio de Janeiro a autora contou com o relato de campo elaborado pelas entrevistadoras.

Foram realizadas 25 entrevistas com os grupos de São Paulo composto por: 6 pesquisadores doutores seniores, 4 doutores, 1 doutorando, 3 mestres e 1 mestrando; e o do Rio de Janeiro composto por: 4 doutores seniores, 2 doutores, 2 doutorandos e 2 
mestrandos. As entrevistas, realizadas no primeiro semestre de 2009, foram gravadas e transcritas para posterior análise.

As entrevistas foram realizadas num período médio de uma hora e meia cada. Algumas delas se estenderam pela vontade e disponibilidade do entrevistado. $\mathrm{O}$ ambiente das entrevistas era privativo. Em sua maioria, foi no local de trabalho dos entrevistados. As exceções ocorreram em São Paulo: houve uma entrevista realizada na residência do entrevistado e seis numa sala da Biblioteca da Faculdade de Saúde Pública.

As entrevistadoras foram orientadas a deixar o pesquisador falar à vontade, principalmente no início da entrevista, quando discorriam sobre a trajetória profissional e acadêmica. Foi uma maneira de descontrair a entrevista para ambos, entrevistador e entrevistado, permitindo uma primeira impressão. Em alguns casos foi necessário interferir nessa primeira parte da entrevista para que não se estendessem demais.

Após a transcrição, feita por profissionais especializados, os textos foram lidos pelas entrevistadoras com a finalidade de completar ou corrigir palavras, especialmente siglas desconhecidas ou que ficaram inaudíveis na gravação.

\subsection{O PROCESSO DE ANÁLISE DOS DADOS}

As entrevistas compõem-se de 25 textos transcritos, totalizando por volta de 450 páginas. A análise dos textos foi feita com base na teoria semiótica da cultura, de modo aberto e experimental, ou seja, buscando informações novas. Os textos decorrentes das transcrições foram lidos com o objetivo de levantar os sistemas de signos que se destacavam para os pesquisadores entrevistados e identificar as invariáveis nos sistemas semióticos. Com base na compreensão das invariantes, foi possível identificar as informações novas que transpareceram nas expressões e que geram sentido na cultura.

O texto é um ato comunicativo no complexo universo das ações humanas e nele estão contidos o dado e o novo, ou criado, que interferem na construção de sentido. A construção de sentido se faz a partir do texto $(\mathrm{KOCH}, 2013)$. Além do intratextual, a análise foi feita no contexto extratextual.

Fizeram parte da análise da linguagem de descrição, conceitos semióticos usados em estudos de metalinguagem, como noções de: signo discreto e contínuo, modelização e memória da cultura. Signos discretos são decomponíveis em unidades, como letras, 
números, notação musical, e signos contínuos são perceptíveis no todo, indecomponíveis, como imagens, ilustrações (MACHADO, 2010). Modelização é a recodificação ou ressignificação da linguagem e memória é o acúmulo de informações com o objetivo de processar mensagens. Esses conceitos e outros similares, não relacionados, vão além da análise semiótica aplicada, pois essas formulações procuraram "compreender as manifestações de cultura para as quais se alcançou uma linguagem de descrição" (MACHADO, 2013b, p. 34).

Um foco importante de análise foi quanto às percepções dos entrevistados sobre a interação com os bibliotecários. Em algumas entrevistas houve menção à presença de bibliotecários e, em outras não, fato esse que foi explorado no momento de análise. Algumas vezes foram apresentados diálogos existentes entre o entrevistado e as entrevistadoras.

$\mathrm{Na}$ apresentação dos resultados, composto por excertos das falas ou de diálogos, algumas palavras ou frases foram grifadas nos textos das transcrições para destacar informações utilizadas na discussão.

Foi realizado um estudo do contexto (meio ambiente) em que se processou a semiose, procurando entender os esforços, os conflitos e as diversidades de relações do ponto de vista dos pesquisadores. A semiose, ou ação sígnica, pode ser representada pela tríade semiótica de Peirce e foi utilizada como unidade básica para o desenvolvimento dos resultados e discussão deste trabalho.

\subsection{ASPECTOS ÉTICOS}

O projeto original, intitulado "Transformações na comunicação científica: identificando necessidades e experimentando tecnologias com grupos de pesquisadores em HIV/aids", foi aprovado pelo Comitê de Ética da Faculdade Saúde Pública da USP e pelo Comitê de Ética da Fiocruz. Os dados foram cedidos pelo coordenador do projeto.

As questões éticas relacionadas à pesquisa com a participação de seres humanos foram respeitadas e o Termo de Consentimento Livre e Esclarecido para os participantes foi redigido tendo em vista a Resolução 196/96. Toda a documentação referente aos aspectos éticos está arquivada de posse do coordenador do projeto acima citado.

Foram usados codinomes para garantir o anonimato dos entrevistados e omitidos nomes de instituições citadas nas entrevistas, quando se referem a críticas. 


\section{RESULTADOS E DISCUSSÃO}

\subsection{CARACTERIZAÇÃO DOS SUJEITOS}

Os pesquisadores entrevistados, sujeitos nesta tese, apresentaram características comuns no que tange ao vínculo institucional e acadêmico, porém diversificadas quanto à formação, faixa etária, experiência com pesquisa e com a temática (Quadro).

Quadro: Características acadêmicas e demográficas dos pesquisadores em HIV/aids entrevistados em 2009.

\begin{tabular}{|l|l|l|l|l|l|l|l|}
\hline Codinome & Cidade & Sexo & $\begin{array}{l}\text { Idade } \\
\text { (anos) }\end{array}$ & Graduação & $\begin{array}{l}\text { Grau } \\
\text { acadêmico/ }\end{array}$ & Instituição & $\begin{array}{c}\text { Atuando } \\
\text { em } \\
\text { HIV/aids } \\
\text { anos) }\end{array}$ \\
\hline Luís & SP & M & 52 & Medicina & Professor & USP & 25 \\
Expedito & SP & M & 67 & Medicina & Professor & USP & 24 \\
Rogério & SP & M & 49 & Medicina & Professor & USP & 9 \\
Ronaldo & SP & M & 49 & Medicina & Professor & USP & 14 \\
Valter & SP & M & 42 & Nutrição & Professor & USP & 3 \\
Raquel & SP & F & 54 & Psicologia & Professora & USP & 22 \\
Marcos & SP & M & 37 & Psicologia & Doutorado & USP & 9 \\
Márcia & SP & F & 56 & Psicologia & Doutorado & USP & 12 \\
Lia & SP & F & 52 & Medicina & Doutorado & USP & 15 \\
Tiago & SP & M & 49 & Medicina & Doutorado & USP & 13 \\
Daniela & SP & F & 38 & Psicologia & Doutoranda & USP & 13 \\
Eliane & SP & F & 38 & Psicologia & Mestre & USP & 17 \\
Cristina & SP & F & 38 & Enfermagem & Mestre & USP & 8 \\
Fátima & SP & F & 41 & Sociologia & Mestre & USP & 15 \\
Luana & SP & F & 29 & Psicologia & Mestranda & USP & 7 \\
M.Helena & RJ & F & 60 & Matemática & Professora & Fiocruz & 14 \\
Marcelo & RJ & M & 46 & Medicina & Professor & Fiocruz & 19 \\
Mário & RJ & M & 30 & Estatística & Professor & Fiocruz & 7 \\
Diana & RJ & F & 40 & Fonoaudiologia & Professora & Fiocruz & 19 \\
Juliana & RJ & F & 29 & Estatística & Doutorado & Fiocruz & 7 \\
Dina & RJ & F & 30 & Psicologia & Doutorado & Fiocruz & 14 \\
Dirceu & RJ & M & 38 & Medicina & Doutorando & Fiocruz & 18 \\
Suely & RJ & F & 27 & Estatística & Doutoranda & Fiocruz & 7 \\
Sofia & RJ & F & 29 & Estatística & Mestranda & Fiocruz & 3 \\
Amanda & RJ & F & 24 & Estatística & Mestranda & Fiocruz & 5 \\
\hline
\end{tabular}

Embora todos os pesquisadores sejam membros de grupos com o foco de estudo em HIV/aids, há interesses específicos dentro dessa temática, sejam particulares ou de subgrupos. A seguir, estão apresentadas as especificidades temáticas de cada pesquisador, bem como um resumo das estratégias utilizadas por eles para atualização pessoal na temática:

- Luís, além da docência, atua na área de assistência num cargo administrativo. Tem interesse em temática variada abarcada por HIV/aids 
e em particular à "patogênese". Usa o serviço de alerta bibliográfico do PubMed.

- Expedito atuou também na Fiocruz como docente. Seu interesse é pela temática "perfil dos médicos prescritores de antirretrovirais e efeitos adversos da terapia antirretroviral". Ele atualiza-se por meio de comunicação com outros autores, predominantemente por email.

- Rogério atua como docente e pesquisa sobre "testagem anti-HIV", recebe alertas de sistemas de informação e participa de listas de discussão. Ele é bastante atuante no grupo NEPAIDS, sobretudo como disseminador de informação científica.

- Ronaldo também atua como docente e seu interesse temático são os assuntos "vulnerabilidade", "prevenção da aids em adolescentes", "problematização entre a questão de vigilância epidemiológica em aids e as questões de direitos", "conflitos morais no cotidiano da pessoa vivendo com HIV". Ele não gosta de receber alertas, mas gostaria de ter um atendimento personalizado, que fornecesse resultados de buscas sistemáticas.

- Valter, professor de nutrição, tem interesse pelos temas "obesidade e estado nutricional em portadores de HIV", "lipodistrofia e HIV". Recebe alertas do PubMed, aprecia os serviços e facilidades oferecidos pelas tecnologias de informação e comunicação.

- Raquel participou da fundação do NEPAIDS, tendo conhecimento de sua história e desenvolvimento. Atua como professora e seu tema é "resposta religiosa a aids". Mantém comunicação com os pares a respeito do seu tema e considera importante reler livros clássicos para aprofundar a teoria.

- Marcos colabora como docente, após o doutorado, e trabalha com os temas "vulnerabilidade ao HIV/aids de turistas" e "órfãos negros e desigualdade". Faz parte de listas de discussão, mas não participa ativamente. 
- Márcia atua como psicóloga em centros de saúde e seus temas são "comunicação do resultado do teste HIV positivo" e "psicanálise e aids". Ela gosta das recomendações de leitura do grupo NEPAIDS e de buscar a informação bibliográfica quando necessário.

- Lia atua como médica em centro de referência na área de assistência e pesquisa sobre "aborto nas mulheres com HIV positivo" e "transmissão vertical do HIV". Procura ajuda na biblioteca e se atualiza com indicações do grupo.

- Tiago atua como médico sanitarista em centro de saúde e pesquisa sobre "prevenção da aids e masculinidade", "gênero e aids" e "violência doméstica e DST/aids". Como membro do NEPAIDS, combinou a prática das atividades no centro de saúde com as teorias estudadas no grupo.

- Daniela atua como psicóloga em centro de referência na área de assistência e pesquisa sobre "gravidez na adolescência e soro-prevalência do HIV" e "risco de infecção pelo HIV em homens que fazem sexo com homens”. Recebe alertas bibliográficos e faz parte de listas de discussão.

- Eliane atua como psicóloga em centro de referência na área de assistência, trabalha como docente em faculdade privada e pesquisa sobre "turismo e vulnerabilidade a aids" e "comunicação de HIV para parceiros". Mantém-se informada pelos contatos nos grupos profissionais em que participa e pelas listas de discussão.

- Cristina trabalhou como enfermeira em hospital e na ocasião da entrevista havia concluído o mestrado. Seu interesse temático é: "aids e religião" e "órfão e estigma". Atualiza-se participando de lista de discussão e grupo de pesquisa (NEPAIDS).

- Fátima atua como pesquisadora de instituto de saúde e pesquisa sobre "mulheres com HIV", "feminismo" e "contracepção de emergência". Prefere procurar a informação quando precisa e não receber grande quantidade de alertas. 
- Luana trabalha numa ONG e pesquisa sobre "branquitude" e "lideranças religiosas e aids". Recebe alertas e usa o SciELO para buscar bibliografia.

- Maria Helena é professora e pesquisa sobre "mulheres profissionais de sexo e HIV". Participa de uma lista sobre a temática de método estatístico, conhecido como RDS, abreviatura de Respondent Driven Sampling pesquisado pelo grupo LIS do Rio de Janeiro.

- Marcelo atua como professor e líder de grupo de pesquisa. Seus temas são "epidemiologia e prevenção do abuso de drogas" e "epidemiologia de HIV/aids". Ele é disseminador de informação científica e participa de várias listas de discussão.

- Mário atua como professor e pesquisa sobre "profissionais do sexo" e "RDS". Atualiza-se por meio da participação em grupos de estudo.

- Diana atua como professora e seu tema de interesse é "prevenção da aids em crianças". Participa de vários grupos e listas de discussão para se atualizar.

- Juliana atua em pesquisa e colabora com o ensino, seus assuntos são "uso de drogas e HIV" e RDS. Usa PubMed para se atualizar.

- Dina atua em pesquisa sobre "testagem HIV", "comportamento de portadores de HIV" e "aderência ao tratamento antiretroviral". Tem familiaridade com as tecnologias, participa de lista de discussão e acompanha redes sociais.

- Dirceu é médico, atuando na área de assistência, e doutorando na Fiocruz. Pesquisa sobre "gordura corporal em pacientes com aids". Gostaria de receber alertas dos assuntos de interesse.

- Suely é pesquisadora contratada de empresa terceirizada que presta serviços à Fiocruz. Cursa doutorado e tem interesse nos assuntos "práticas sexuais e prevenção da aids", "métodos estatísticos para análise de dados para HPV (RDS)" e "profissionais do sexo". Gostaria de receber alertas sobre as publicações dos assuntos de interesse. 
- Sofia, além de cursar o mestrado, presta serviços à UERJ na área de estatística. Sua pesquisa é sobre "HIV em homem que faz sexo com homem" usando a metodologia RDS. Usa a lista do RDS para se atualizar.

- Amanda cursa o mestrado e pesquisa sobre "usuário de drogas e HIV", "população de risco e aderência ao tratamento (RDS)" e "vulnerabilidade e HIV”. Faz parte de lista de discussão. 


\subsection{A TRÍADE: TEXTOS, SIGNIFICANTES E INTERPRETANTES}

A tríade semiótica de Peirce é um modelo filosófico que serve de base para exemplificar o signo em sua evolução contínua. Embora Peirce tenha dedicado seus estudos em aprofundar a lógica triádica, neste trabalho não será explorada a sua teoria, somente será utilizado o conceito de tríade para elucidar a apresentação dos resultados e articular a discussão.

Uma tríade semiótica representa um objeto e a sua correlação percebida por um terceiro. Peirce também trabalhou com várias tríades, neste trabalho será utilizada a conhecida como signo-objeto-interpretante (SANTAELLA, 2002). Será usada a definição de PEIRCE (1977) para signo: tudo aquilo que, aos olhos de alguém, está no lugar de alguma outra coisa sob algum aspecto ou capacidade. A tríade desenvolve-se numa cadeia semiótica infinita, a correlação entre signo e objeto por um interpretante torna-se um novo signo, correlacionado com outro objeto e assim por diante.

Com base nessa tríade foi construído um diagrama para representar a unidade básica da apresentação dos resultados e discussão deste trabalho (Figura 8).

Figura 8 - Diagrama representando a unidade básica da interpretação dos resultados, com base na tríade de Peirce.

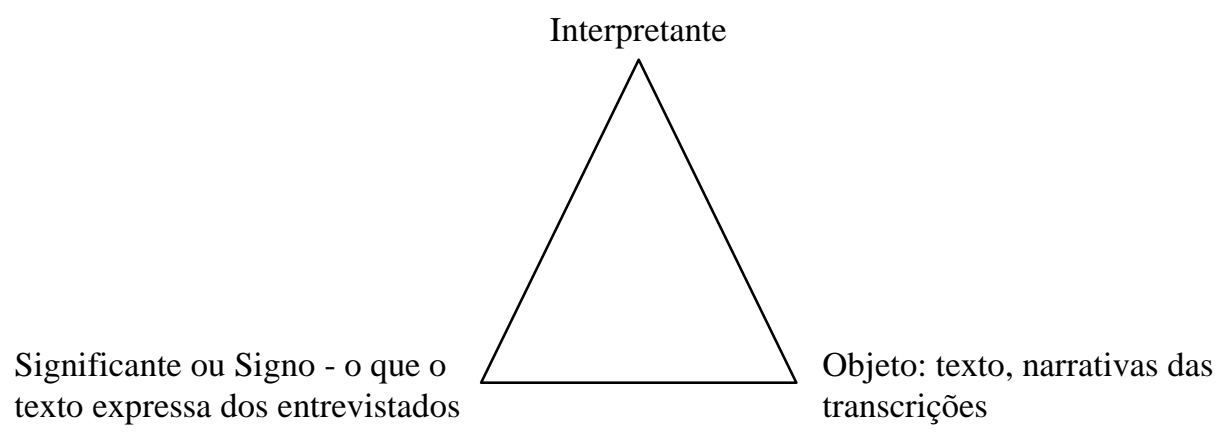

O espaço semiótico ou semiosfera é um conjunto de sistemas de signos e linguagens em constante transformação. Por se tratar de um espaço de caráter abstrato, será usada essa tríade para representar o ponto de partida de experimentação da semiosfera. Em resumo, a tríade é composta do texto das entrevistas e suas traduções e expressões das linguagens, identificadas sob um ponto de vista interpretativo.

A primeira tradução de linguagem ocorreu na transcrição da linguagem oral para a linguagem escrita. Ao se expressar oralmente, as pessoas tendem a ser mais impulsivas e lançar as frases numa organização lógica pouco elaborada, principalmente 
em entrevistas cujo conteúdo é desconhecido previamente. O texto construído na entrevista é uma forma de dar sentido às situações e levantar as percepções dos pesquisadores. A expressão do sentido é o significante da tríade.

O interpretante completa a tríade, denotando além de uma simples interpretação. O interpretante constitui-se das informações novas reveladas na leitura, que são codificadas, decodificadas, recodificadas e transformadas no texto deste estudo. $\mathrm{O}$ processo continua infinitamente com novas relações do significante com o objeto.

O texto falado, no processo de transformação para o escrito, modela a linguagem. São vários sistemas em interação: palavras, gestos, sons, transformados em texto escrito. Assim, o texto passou por vários processos de leitura e tradução: a associação e relação dos sons e palavras faladas, a transcrição do som para o texto escrito, a leitura da escrita, que também demandou uma compreensão e interpretação.

Todo o processo de codificação e decodificação foi levado em consideração na interpretação, uma vez que a fala e a escrita não são modalidades dicotômicas de uso da língua, mas apresentam tipos de complexidade diferentes. O texto escrito apresenta maior densidade lexical (repertório de palavras) e o falado, maior complexidade sintática (disposição da ordem nas frases). Em algumas situações, os textos escritos se aproximam mais do polo da fala, com em bilhetes e em textos de humor. O mesmo ocorre com os textos falados que, às vezes, aproximam-se da escrita formal, como em conferências e entrevistas profissionais (KOCH, 2013).

No caso dos textos das entrevistas deste trabalho, algumas vezes a fala aproximou-se muito da escrita formal em frases construídas ordenadamente e bem elaboradas, como no exemplo a seguir do Prof. Rogério:

A desnutrição hoje não é mais um problema, é uma tragédia que persiste ainda em alguns lugares, mas são pequenos bolsões..., mas hoje o problema é a obesidade. Aí, eu não me encantei muito pela obesidade.

Entretanto, na maioria das vezes, observou-se que, no decorrer das entrevistas, as pessoas mostravam-se estar mais à vontade e a fala fluía mais espontaneamente, como no seguinte exemplo, do mesmo professor:

Dele [Robert, disseminador de informação em lista de discussão especializada] eu tenho guardado tudo. Porque, digamos assim, eu não estou fazendo a revisão sistemática periódica, eu tenho uma pastinha para a lista dele, eu dou uma olhada se é meu assunto. Se é meu assunto eu já fico aí, vou atrás. 
Nesse último exemplo fica difícil a compreensão da mensagem, sobretudo na contradição da última frase: ele "fica aí" ou "vai atrás"? O pesquisador quis dizer que segue uma lista, procurando uma referência, e que, quando a encontra, para de olhar a lista e vai procurar o artigo a que se refere o registro. Para compreender esse raciocínio é preciso entender o contexto, perceber o conjunto. Num processo de comunicação, às vezes, a mensagem é reformulada, adquirindo novo sentido, e um novo código é introduzido, tratando-se de autocomunicação na cultura. Como entrevistado e entrevistador são membros de uma mesma cultura, é possível o entendimento da mensagem.

A atitude do pesquisador colabora para a fala ser mais ou menos espontânea, uma vez que o diálogo se dá dentro de um "continuum tipológico de práticas sociais" (KOCH, 2013, p.77).

É importante destacar algumas diferenças entre a fala e a escrita, lembrando que essas características não são exclusivas de uma ou de outra. Conhecendo as características de cada modalidade é possível identificar as variações encontradas nos textos das entrevistas.

Para KOCH (2013), a fala é contextualizada, implícita, redundante, não planejada, fragmentada, incompleta, pouco elaborada e com predominância de frases curtas e simples. A escrita é descontextualizada, explícita, condensada, planejada, não fragmentada, completa, elaborada e com predominância de frases complexas e com subordinação abundante.

Dependendo do contexto, porém, o texto falado pode ser estruturado pelas circunstâncias sociocognitivas de sua produção, como numa entrevista ou diálogo em que o texto resulta de mais de um interlocutor, ou seja, é construído a partir de uma interação entre duas ou mais pessoas. No exemplo a seguir, observa-se essa situação de construção de sentido a partir da entrevistadora e da professora Diana, entrevistada:

Diana: (...) Como você vai dizer que a população, em que sentido? Não é biológico, é social? Então foi feito.

Entrevistadora: É econômico? Porque tem uma...

Diana: Tem uma dimensão...

Entrevistadora: Claro, exatamente.

Diana: ... mas, se é econômico também vai atingir o branco pobre, então não era a cor. 
Entrevistadora: Daí em dois mil e pouco, né? Porque eu até lembro já de ter lido esse artigo. Ele é dois mil e...

Diana: Ele é mais recente, ele é dois mil e sete acho, eu tenho ele ali, ele é dois mil e sete.

A entrevistadora completa frases da pesquisadora e vice-versa. Como fazem parte da mesma contextualização, foi possível a compreensão de ambas. Entretanto, a compreensão do diálogo fica prejudicada para quem lê somente o texto fragmentado.

As reflexões metodológicas de SCHRAIBER (1995) sobre a ferramenta utilizada para coleta, entrevista, lembram também que o uso de gravador denota ao entrevistado que o relato será público, podendo inibi-lo ou trazer uma preocupação excessiva com o desempenho pessoal. Outra provável causa de inibição ou de modelizador das respostas diz respeito ao conhecimento dos objetivos da entrevista (conhecer as transformações na comunicação científica) e dos líderes que coordenavam o projeto (um professor de São Paulo e um do Rio de Janeiro). Esses dois professores lideram grupos de pesquisa e dominam as linguagens de busca dos sistemas de informação, atuando como multiplicadores da área. Em algumas entrevistas, um deles foi nomeado de "nosso google", "oráculo", "Hub", palavras que sugerem alguém conhecedor dos recursos informacionais (ALVAREZ e col., 2013). No exemplo a seguir está um trecho em que o bioestatístico Paulo, do Rio de Janeiro, refere-se ao líder do grupo como "enciclopédia ambulante":

Sim, isso sim. O Marcelo, a Maria Helena, o Augusto essa semana me mandou um sobre aids, da NEMES. Na verdade, eu só recebo isso, por exemplo, a Maria Helena quando lê um artigo interessante e ela acha que vai ser útil para aquilo que eu estou fazendo ela me manda, o Augusto, quando acha alguma coisa, também sempre manda, o próprio Marcelo mesmo. Quando eu preciso de alguma coisa eu recorro ao próprio Marcelo. O Marcelo é uma enciclopédia ambulante. (risos)

A transcrição, apesar de ser considerada pouco relevante nas alterações do conteúdo, transforma a linguagem oral, gerando um novo texto (narrativa). Muitos gestos, momentos de silêncio e apreensão não foram considerados na interpretação, com exceção das entrevistas realizadas com o grupo paulista, em que a autora deste trabalho esteve presente.

Uma entrevista recupera acontecimentos passados, que fazem parte da memória do entrevistado. Essa lembrança é individual, mas traz consigo a memória da coletividade (SCHRAIBER, 1995). A memória da cultura é uma das três funções do 
texto, acompanhada da função comunicativa e a criativa ou geradora de sentido (LÓTMAN, 2000). No exemplo abaixo, o Prof. Ronaldo usa a memória individual para se lembrar de um fato em que precisou buscar material bibliográfico na Biblioteca. "Buscar material bibliográfico na Biblioteca" é algo comum em universidades fazendo parte dos costumes dos indivíduos que dela participam:

Já aconteceu, não comigo diretamente, quer dizer comigo bem mais para trás, que, se não me engano, foi até a questão que o ... Pediu para mim, que era um material que não tinha aqui na $X$, mas que a $X$ localizou e conseguiu trazer para cá, isso faz tempo. Mas, recentemente já aconteceu com aluno de me pedir artigo e ver nas bibliotecas, mas eu também não tenho detalhes como é que foi.

Após essa descrição de algumas traduções e modelizações de linguagem, observadas na semiosfera, foi realizado o exercício de compor relações entre as narrativas dos entrevistados. A riqueza das informações observadas nas transcrições das entrevistas individuais espelha a complexidade dos resultados. A percepção dos pesquisadores diante das questões sobre a busca por informação coincide entre alguns, em dados momentos, mas divergem em outros. A homogeneidade dos grupos revela-se em certas expressões, mas se contrapõem em outras. Não foi possível caracterizar os grupos de São Paulo e do Rio de Janeiro de modo a distingui-los e tão pouco foi possível caracterizar objetivamente os grupos pelas formações e atividades profissionais desenvolvidas, embora concordâncias e semelhanças possam ser percebidas em várias colocações.

A participação da entrevistadora direcionou a entrevista, como previsto para esta ferramenta e outras diversidades identificadas (QUEIROZ, 1987). O roteiro, apesar de focado, permitiu diferentes abordagens pelos entrevistados e foi transformado em cada uma das entrevistas. Esse é mais um exemplo de modelização do texto. Cada entrevista foi única, porém foi possível fazer agrupamentos para dialogar com os textos resultantes.

O grupo de São Paulo é composto na sua maioria por biomédicos e o do Rio de Janeiro por pessoas com formação na área de exatas (estatísticos e matemática). Essa distribuição não influenciou nas respostas sobre bases de dados. A base PubMed, especializada em biomedicina, foi citada na mesma proporção nos dois grupos, uma vez que os grupos pesquisam assuntos referentes ao HIV/aids, inserido sobretudo na área biomédica. 
A faixa etária não determinou diferenças no que diz respeito ao uso das novas tecnologias. Os pesquisadores mais velhos usam sistemas tanto quanto os mais jovens. A expectativa de encontrar informações em textos completos de artigos científicos, gratuitamente e sem burocracia, está presente nas entrevistas, como nos dois momentos relatados abaixo com pesquisadoras em faixas etárias distantes (60 e 24 anos):

Entrevista 1 (60 anos)

Maria Helena: O acesso livre? Quer dizer, ele ter o artigo completo? Entrevistadora: É...

Maria Helena: Na verdade, se ele usar o SciELO, ele já tem, né? E mesmo lá no PubMed, se ele for pelo PubMed...

Entrevista 2 (24 anos)

Entrevistadora: $O$ que, que você acha assim, o que você gostaria de ter à disposição que facilitasse sua busca. Tenta imaginar alguma coisa...

Amanda: Ter acesso em casa. [Risos] Para facilitar é isso, se bem que eu estou aqui o tempo todo, a maior parte do dia.

Entrevistadora: Ter acess, que você diz, é ter os artigos completos?

Amanda: Isso.

Da mesma forma que a idade não interferiu, não foi percebida diferença no uso das tecnologias para busca de informação entre os sexos masculino e feminino. Um fato observado é que o número de professores é maior que o número de professoras nesses grupos de pesquisa, mas isso não está abarcado nos objetivos deste trabalho.

Quanto ao grau acadêmico, percebem-se diferenças entre os professores, mais experientes na lida com a informação, e os estudantes de mestrado e doutorado. Muitos estudantes mencionam que os professores fornecem indicações bibliográficas. A estudante Cristina informa que seu orientador lhe ensinou a usar bases de dados:

Entrevistadora: E os processos de levantamento em si? Como você aprendeu?

Cristina: Então, o Rogério... me deu várias aulas... prá gente, durante meu primeiro mestrado (...)

O professor Marcelo também ajudou o estudante Dirceu no doutorado:

Entrevistadora: Qual foi a última vez que você precisou de informações científicas pra esse projeto?

Dirceu: O Marcelo é joia. O Marcelo é joia. O Marcelo falou assim: 'Dirceu, faz um bom trabalho de pesquisa'. Então, ele falou assim: 'um bom protocolo, tem que ter um bom protocolo'. Então, foi essa a última 
vez, em 2007, que eu precisei de informação no grosso, no grosso mesmo.

Refletindo sobre a parte e o todo, o individual e o coletivo, recuperamos em MORIN (2004) as reflexões sobre o pensamento de Pascal, de estudar as partes relacionadas com o todo e vice-versa para que o conhecimento nasça de uma visão sistêmica e o todo não seja redutível às partes. Ao abordar a transformação do texto e a semiosfera, LÓTMAN (1996) mencionou que se juntarmos várias vitelas não obtemos um bezerro, mas se fatiarmos um bezerro, obtemos muitos pedaços de vitela. Esse pensamento foi interpretado por ECO (2000) com outra metáfora: para entender uma floresta, não basta colocar ramos e folhas juntos, mas se soubermos como trilhar na cultura da floresta com olhos abertos, seguindo pistas, teremos competência para entender a vastidão e complexidade da floresta e descobrir a natureza das folhas e ramos de cada árvore.

Assim, para estudar a semiosfera não basta somar os atos semióticos particulares, mas, "ao contrário, somente a existência de tal universo - da semiosfera percebe o ato sígnico particular" (LÓTMAN, 1996, p.24).

Com base nesses pensamentos, a análise dos textos percorreu o raciocínio de transformação da informação na cultura e a leitura foi uma interpretação em busca das informações novas ou do imprevisível no processo de diálogo. As interpretações que se desenharam nos coletivos não emergiram da soma das entrevistas individuais, mas compõem muito mais do que as frases digitadas nas transcrições. Vários agrupamentos podem ser feitos com base nas informações novas registradas nos textos. Numa mesma cultura acadêmica percebem-se características de outras culturas, dependendo das delimitações do observador. Isso ocorre num movimento contínuo, são várias fronteiras unindo esferas de semiosis.

$\mathrm{Na}$ semiosfera, observam-se a desigualdade e a unidade, a assimetria e a uniformidade (LÓTMAN, 2000). Essa binaridade é explicada pelo que há dentro da semiosfera, ou o que faz sentido para a cultura, e o que é desconhecido, que está fora da semiosfera. Por isso, estudar a fronteira da semiosfera é importante; o que causa estranheza é a semente que poderá gerar novos códigos e linguagens e se aproximar do centro da cultura, num movimento constante. Para LÓTMAN: "os pontos mais importantes para os processos de semiotização são as fronteiras da semiosfera. A noção de fronteira é ambivalente: separa e une" (2000, p.136). 


\subsection{O CENTRO DA SEMIOSFERA}

A irregularidade semiótica é expressada do ponto de vista do observador, dependendo de onde fica a fronteira de uma dada cultura. Na semiosfera, segundo LÓTMAN (1996, p.30), "se viola a hierarquia das linguagens e dos textos: eles colidem como linguagens e textos que estão no mesmo nível. Os textos estão submersos em linguagens que não correspondem a eles, e os códigos que os decifram podem estar ausentes do todo".

Essa irregularidade estrutural do espaço semiótico leva a um processo dinâmico, que é um dos mecanismos de produção de informação nova. O texto traz fragmentos da estrutura da linguagem que o gerou e tenta reconfigurar-se para gerar sentido. Dessa forma reconstrói a linguagem perdida numa nova modelagem.

“A divisão em núcleo e periferia é uma lei da organização interna da semiosfera" segundo LÓTMAN (1996, p.30). Na periferia da semiosfera a organização é menos rígida e, por ser mais flexível, desenvolve-se rapidamente e pode ocupar o núcleo. Na periferia ficam textos isolados, perdidos. Na estrutura central ficam as linguagens estruturadas e, por estarem mais voltadas a si mesmas e serem mais rígidas, desenvolvem-se mais devagar e podem mudar de posição.

Com base na irregularidade semiótica, a seguir, serão apresentados alguns sistemas de signos abordados na cultura e considerados centrais na semiosfera. Os sistemas de signos são percebidos pelos pesquisadores conforme a posição de observador em relação à fronteira da cultura (Figura 9). Como eles percebem e modificam o objeto "estratégias de busca de informação técnica científica"? 
Figura 9 - Diagrama representando a semiosfera e os observadores.

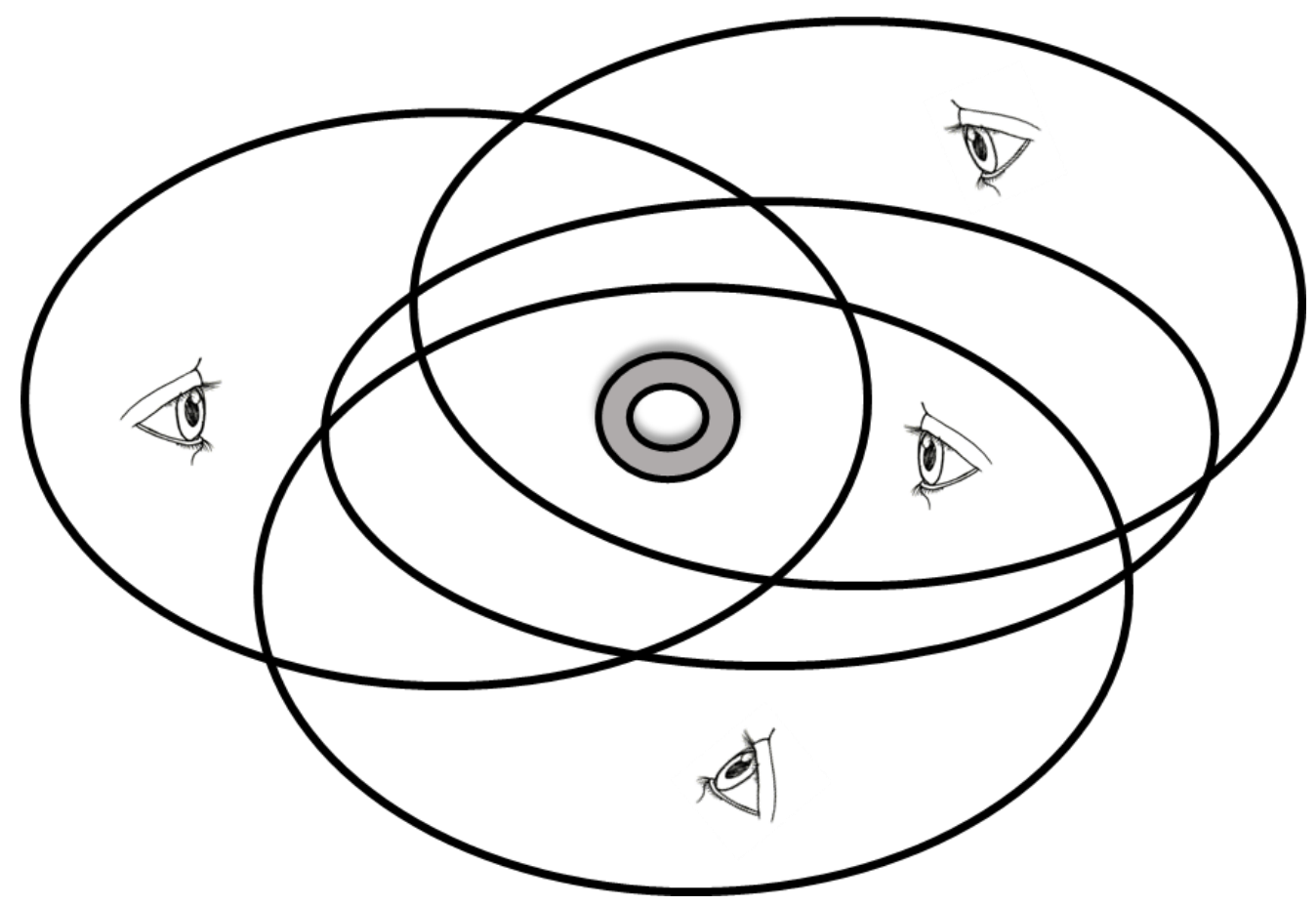

Os entrevistados criaram textos, com base na linguagem natural, e pontuaram diversos signos, que, identificados, formam os sistemas da cultura. $\mathrm{O}$ sentido dos signos é diferente do encontrado num dicionário, pois são organizados numa linguagem específica da cultura. A linguagem específica é resultado da transformação da linguagem natural "num nível mais alto, num sistema modelizante secundário" (TOROP, 2003, p.82). As entrevistas apresentam algumas palavras com denotações próprias do ambiente acadêmico e referentes a sistemas para buscar informação científica. Nessa semiosfera foram selecionados os sistemas, que, para a cultura acadêmica, mais refletem as estratégias de busca de informação técnica e científica: o Google, o PubMed e o MeSH.

Um sistema de signo não selecionado, mas também importante para a cultura acadêmica, é o SciELO (Scientific Electronic Library Online), citado em 60\% das entrevistas, mas qualificado como coadjuvante pela maioria dos entrevistados. Por se tratar de uma coleção de revistas e artigos eletrônicos multidisciplinares, não se classifica como base de dados bibliográfica para rastrear a literatura da área da saúde. Dessa forma não foi dado um destaque central para essa fonte de informação, embora alguns pesquisadores o considerem fundamental, como nas falas a seguir: 
(...) eu tenho trabalhado com SciELO, por ser uma biblioteca pública, por ser, tô usando essa palavra, mais democrática, a gente vê que pode ser acessível prá qualquer lugar. (Diana)

(...) mais fácil do que entrar nos periódicos Capes. Às vezes pelo SciELO você encurta o caminho. Porque às vezes você acha no PubMed, encontra o periódico, tem que baixar o arquivo. É mais difícil para baixar o arquivo, e no SciELO você vai direto. (Juliana)

(...) essas bases que agora estão colocando os artigos online na íntegra, isso dá uma facilidade! O SciELO é uma benção, [risos], é um "cielo”... (Ronaldo)

(...), SciELO tem sido, cada vez mais, um lugar muito interessante de você buscar. (Luana)

Para os sistemas de signos selecionados (Google, PubMed e MeSH), o desenvolvimento do texto foi elaborado como nos estudos literários, ou seja, pela expressão descobre-se o conteúdo, a denotação comum para a cultura. O ponto de intersecção das ligações intratextuais e extratextuais demonstra que esses sistemas de signos estão se estruturando no centro da semiosfera da cultura acadêmica.

\subsubsection{Google}

Ao se tratar de busca por informação, o uso de uma ferramenta surge nas falas dos pesquisadores: o Google. No roteiro da entrevista não constava uma pergunta específica a respeito do seu uso e foi abordado em poucas ocasiões pelas entrevistadoras, porém o tema foi expresso pelos pesquisadores nas entrevistas.

Cinco pesquisadores disseram usar o Google preferencialmente, outros dez informaram utilizar o Google, mas não o definiram como ferramenta prioritária. Dois deles disseram não usar o Google para busca bibliográfica e os demais, oito, não citaram o Google na entrevista. A maioria referiu-se ao Google, destacando o Google Acadêmico, justificando a escolha por ser uma ferramenta que filtra os resultados em trabalhos técnicos e científicos. Uma pesquisadora, a socióloga Fátima, disse que o Google é uma "poluição":

(...)pra que eu entrar na internet, no, sei lá, o Google Acadêmico? Tem 60 pesquisas de campo estudando coisas parecidas. É lindo no congresso, é lindo pra movimentar o Brasil, mas, teoricamente, isso é uma babaquice...

Os pesquisadores, que assumiram a preferência pelo Google, eram, em sua maioria, formados em psicologia e atuavam em atividades variadas na cidade de São 
Paulo: ensino, assistência à saúde, integrante de ONG, estudante de pós-graduação. Um médico, Tiago, elogiou o Google e crê que tudo o que há publicado está disponível por essa ferramenta:

Google Scholar é uma beleza, você, chega lá e pesquisa tudo o que tem, é saber, pelo menos, tudo o que tem.

Um dos psicólogos, o professor Marcos, disse que está satisfeito com o Google Acadêmico porque acredita que essa ferramenta engloba várias bases de dados e quase tudo o que é importante para usar nas suas pesquisas:

Primeiro (busco) no Google acadêmico, sempre. Em geral, o Google acadêmico me satisfaz. Hoje, atualmente, eu não sei até quando vai durar esta festa, quando as revistas vão cortar a onda do Google acadêmico, mas antes ficava muito atomizado. $O$ assunto, então, eu preciso olhar na BVS Psi - que é Base de Dados da Psicologia, eu preciso olhar na BIREME/LILACS. Agora você põe no Google e ele indexa todas essas. Então eu acho que é um instrumento fascinante por causa disso, essa possibilidade de você ter quase tudo ali, ele deixa escapar muito pouco, né?

Três professores, considerados familiarizados com tecnologias de informação e comunicação, informaram utilizar várias bases de dados especializadas e o Google Acadêmico. Um deles, Rogério, expressou:

(...) mais recentemente, eu tenho me pego usando duas fontes fundamentalmente, agora, uma é o Scholar Google, que a gente também não sabe o que tá acontecendo por detrás.

O que há por traz dessa palavra "Google", citada pelos pesquisadores e conhecida por uma geração?

Google é o nome de uma empresa multinacional americana de serviços online e software, fundada em 1998, que hospeda e desenvolve serviços e produtos com base na internet ${ }^{*}$. Seu lucro é gerado pela publicidade. Google tem a ambiciosa missão de "organizar as informações do mundo e torná-las mundialmente acessíveis e úteis" (www.google.com.br). Os pesquisadores referem-se ao Google não como uma empresa, mas como uma ferramenta para buscar informações ou textos disponíveis na internet.

O Google Acadêmico, modalidade preferida pelos pesquisadores é um recorte do Google para recuperar a literatura acadêmica: artigos revisados por especialistas, teses,

\footnotetext{
* Disponível em: https://www.google.com.br/intl/pt-BR/about/
} 
livros, resumos, organizações profissionais, pré-publicações, universidades e outras entidades acadêmicas. O Google Acadêmico também oferece as estatísticas das citações de cada trabalho ou registro, classificando-os por relevância* .

O número de usuários do Google Acadêmico está crescendo, sobretudo na China, e seus serviços estão se aprimorando, segundo informações de BOHANNON (2014). Há outras empresas interessadas em desenvolver o algoritmo para citações, como a Microsoft, mas isso ainda não foi apresentado à comunidade acadêmica. Para esse autor seria importante haver outras opções aos cientistas, para não dependerem somente de um serviço. Entretanto, o Google ainda domina o algoritmo secreto, que constrói um ranking de páginas na web segundo a frequência de uso entre as páginas que estão ligadas a ela (DARNTON, 2010).

Google está no centro da semiosfera da comunidade acadêmica, como parte de um código. POSNER (1995) identifica como código central da cultura aqueles que se revelam por ter uma extensa distribuição, em grande frequência e alto prestígio na sociedade.

Esse instrumento/empresa/oráculo Google tem sido objeto de várias reflexões em trabalhos técnicos e científicos. Destaca-se um estudo chamado Geração Google, conduzido por um grupo do Centro de Pesquisa sobre Comportamento de Busca da University College London (http://www.ucl.ac.uk), que está investigando como os jovens buscam informação e as implicações para as grandes coleções de pesquisa do país. O estudo vai tentar abordar se as novas maneiras de buscar a informação interferem nos resultados de pesquisa, comparando com as buscas feitas pelas gerações anteriores, consideradas tradicionais para a área da ciência da informação.

A "geração Google" é uma frase popular que se refere a uma geração de jovens, nascidos depois de 1993 e que se desenvolvem num mundo dominado pela internet (ROWLANDS e col. 2008). Algumas características dessa geração foram mencionadas por ROWLANDS e col., destacando que a grande maioria desses estudantes usavam o Google como ferramenta de busca principal e que poucos deles usavam os portais das bibliotecas. Essa geração quer respostas rápidas, fazem as buscas intuitivamente, usam as tecnologias cada vez mais cedo, mas apresentam dificuldades para selecionar e avaliar as informações que encontram.

\footnotetext{
* Disponível em: http://scholar.google.com.br/intl/pt-BR/scholar/about.html
} 
O Google, antes localizado na periferia da cultura acadêmica, tomou lugar nas proximidades do centro da cultura. Podemos fazer um paralelo com o exemplo citado por LÓTMAN (2000) sobre a vestimenta jeans, que no início do século 20 era usado por trabalhadores, estando na periferia da cultura, e depois foi adotado pelos jovens como uma vestimenta comum para todos, que é a característica mais importante dos sistemas semióticos do centro. O Google, a princípio, usado pela população mais jovem com acesso à internet era considerado um instrumento para buscas de informações recreativas, irrelevantes para a ciência. Com o passar do tempo, o Google passa a ser utilizado pela área acadêmica. ROWLANDS e col. concluíram que as diferenças entre os modos de busca da geração mais jovem e mais velha, entre os professores e estudantes tendem a deixar de existir e que todos se tornariam da "geração Google" (2008).

Cientistas da informação procuram estudar esse sistema de signo central na cultura para compreender o que essa empresa pode fornecer de instrumentos para colaborar na busca da informação e conhecer as possíveis ameaças para as missões das bibliotecas de preservar e divulgar a informação de qualidade. A literatura científica tem apresentado diversos trabalhos abordando as oportunidades e ameaças do Google para as bibliotecas e para o desenvolvimento do conhecimento. DARNTON (2010) considera que o Google é uma empresa, um monopólio dedicado a conquistar mercados e está longe de ser um aliado das bibliotecas.

Outro autor, HOCHET (2012), questiona as metas obscuras do Google, seus líderes discretos demais e seus equipamentos servidores escondidos. Menciona que, por trás da empresa, que se mostra democrática, há uma corporação paternalista com fins publicitários e monetários. Buscas idênticas realizadas no Google em dois computadores, ao mesmo tempo, apresentam resultados diferentes, devido à personalização pelos algoritmos. Isso leva ao risco de confinamento progressivo dos usuários, que sempre encontrarão aquilo que procuram. Embora positivo, esse fato faz o usuário perceber que está com sorte e que tudo o que precisa está naquele resultado, limitando a possibilidade de conhecer o diferente. HOCHET acredita que é necessário conhecer todos os recursos do Google para um uso mais eficaz e que as bibliotecas podem acrescentar esse instrumento nos seus programas educativos com o objetivo de desenvolver a competência em informação de seus usuários. 
O protecionismo de culturas e línguas pelo Google é abordado por ABADAL e CODINA (2008), que mencionam as restrições algorítmicas inseridas nos mecanismos de busca feitos na China para atender ao Governo e os resultados priorizando o idioma inglês, mesmo quando se referem a trabalhos escritos originalmente em outros idiomas. Esses autores espanhóis criticam a imposição da cultura norte-americana e do idioma inglês por meio dos sistemas de busca de informação, destacando o Google.

Resta saber como será esse movimento na cultura acadêmica nos próximos anos. Por quanto tempo o Google estará no centro da cultura, o que vai surgir de novo? A previsão de LÉVY* é que o Google vai passar, apesar de poderoso, e que não há necessidade de preocupação, pois "o que permanece é o crescimento da capacidade cognitiva humana" com a democratização do big data, o aumento da alfabetização básica e digital e o pensamento crítico.

O sistema de signos Google formou-se a partir da estrutura de outros sistemas de signos presentes na cultura acadêmica como o sistema de busca das bases bibliográficas. O seu diferencial é ser, ou pretender ser, um sistema gratuito, de livre acesso. Essa transformação foi possível porque na semiosfera há diálogo ente os sistemas e linguagens.

\subsubsection{PubMed/MEDLINE}

Outro sistema de signo no centro da cultura acadêmica da área da saúde é a base de dados PubMed ou MEDLINE, que organiza e indexa revistas especializadas da área da biomedicina do mundo todo. Essa base de dados é tradicional para busca de informações científicas. Inicialmente estava disponível por meio de bibliografias (Index Medicus), publicadas mensalmente pela Biblioteca do Exército dos Estados Unidos, que mais tarde tornou-se a Biblioteca Nacional de Medicina dos Estados Unidos (National Library of Medicine). Com o desenvolvimento tecnológico, essa coleção periódica foi ficando disponível em outros suportes, como disquetes, CD Rom e online. MEDLINE é

\footnotetext{
* Lévy P. Ciberdemocracia hoje [palestra proferida no SENAC, São Paulo, 2014]
} 
o nome da base de dados e PubMed é o nome da versão gratuita da mesma base, incluindo os registros ainda não validados pela instituição*

Nas entrevistas com os pesquisadores, o uso do PubMed apareceu em quase todas. Das 25 entrevistas, somente não foi mencionada em quatro delas e dois pesquisadores disseram não utilizar esse recurso.

Marcos e Raquel, dois professores formados em psicologia, informaram usar quando necessário, preferindo usar o Google Acadêmico para buscar informações. A seguinte fala da Raquel ilustra essa posição, parecendo indicar hesitação:

(...) atualmente eu estou fazendo uma coisa, totalmente anti, que é Google Acadêmico, tá certo? Boto três, quatro palavras no Google Acadêmico e vou olhando o que, que vai saindo, né? Vou pelo Google, e a partir do que eu acho ali é que eu vou atrás, tá certo? Eu quase não entro mais em MEDLINE, por exemplo, eu entro no MEDLINE basicamente, indiretamente, pra achar as coisas que o Google... Eu começo pelo Google Acadêmico e vou pelo, e vou pela, MEDLINE pra confirmar a busca que eu tô fazendo entendeu?

A hesitação, segundo KOCH (2013) evidencia-se pela colocação de perguntas no final das frases, como "tá certo?", “né?" e “entendeu?”, além das pausas observadas nessa entrevista. As pausas também são manifestações de hesitação que, para $\mathrm{KOCH}$ (2013), ocorrem com frequência na linguagem falada e, normalmente, é usada para ganhar tempo. No caso da pesquisadora, tal hesitação, se apropriada, pode referir-se a familiaridade com a tecnologia.

Nessa fala, a professora procura justificar o não uso da base considerada tão importante para o grupo biomédico. Ela emprega a palavra "anti" para explicar o contrário do que se espera de um pesquisador nessa área e se justifica ao dizer que usa a base MEDLINE para confirmar a busca efetuada no Google Acadêmico.

Algo parecido aconteceu com a fala de uma pesquisadora de São Paulo, Fátima, socióloga, que fez crítica ao uso da base MEDLINE, usando uma palavra no diminutivo para qualificá-la: "coisinha", bem como o termo "idiota". Ela disse que utiliza a base de dados para agradar o revisor:

\footnotetext{
* Disponível em: http://www.ncbi.nlm.nih.gov/books/NBK3827/\#pubmedhelp.FAQs
} 
Então eu nem preciso ver na Internet, porque eu sei que quando tem, alguém já me liga [...] Mas eu faço só para o internacional [...] Eu faço um MEDLINE[...] Eu faço um MEDLINE, aquela coisinha até, às vezes, idiota, às vezes não, só pra agradar o revisor, né?

Essa entrevista merece um destaque. A pesquisadora, uma socióloga, foi bastante espontânea no seu discurso e crítica em relação à pesquisa científica e aos sistemas de busca em geral. Em alguns momentos enviou mensagem para o coordenador da pesquisa, que foi citado em partes da entrevista. Ao final da entrevista, a entrevistadora comentou, em tom de brincadeira, que ela havia subvertido toda a entrevista e transformado o roteiro.

O discurso da socióloga diverge do discurso esperado de um pesquisador em saúde, mais formal. Assim, ela apresentou informações novas, foi uma entrevista bastante criativa e imprevisível. Discorrendo sobre a imprevisibilidade, LÓTMAN menciona que a "metáfora chocante é sempre o resultado de um ato criativo" (1999, p. 36), aquela que o sentido tradicional avalia como arbitrária e ofensiva é a que apresenta novos sentidos e ideias levando o indivíduo à reflexão. Segue a parte em que a socióloga comenta sobre o coordenador da pesquisa:

Porque o perfil do Rogério e do Ronaldo, eu vou meter o pau e ele vai ler... [Risos] é bem acadêmico mesmo, entendeu? Então eles querem publicar (...) Mas eu gosto do Rogério, (...), apesar de eu achar que eles são muito acadêmicos. [Risos]

Nessa colocação a socióloga aponta para a característica acadêmica de dois participantes do grupo de pesquisa. Ela atua na área de assistência, mais técnica, e, ao mesmo tempo, participa de um grupo que desenvolve teorias de caráter mais acadêmico. Há uma divergência de valores explicitados no discurso.

O outro professor citado pela socióloga é do grupo de São Paulo, Ronaldo, médico, que indicou achar mais conveniente buscar a informação bibliográfica por meio de busca relacionada:

(...) uma citação até no PubMed mesmo, mas aí tem aquele link das obras relacionadas, aí você clica alí e vai. E, às vezes, uma coisa que eu faço também: eu tenho um autor que tem um título, que parece interessante, e eи vou e dou um Google no autor, aí eu quero pegar mais transversalmente coisas que ele publicou, indexações diferentes, ou citações dele. 
Uma pesquisadora do Rio de Janeiro, Sofia, estatística, disse ter dificuldade em utilizar o PubMed:

Eu não sei se é um problema meu, sabe? de usar pouco, mas eu acho que é assim, um grande problema. É que é assim, muitos artigos estão disponíveis, mas muitos não estão.

Outra professora do Rio parece ter também dificuldades. Ela disse que utiliza os serviços de estagiárias para localização dos trabalhos, mas informou que seria bom poder refinar as buscas, fato que já é possível:

É, nas bases, mesmo que não fosse..., que houvesse interseção, se você colocar lá epidemiologia ou métodos quantitativos, já seria alguma coisa assim, aí você já vai direto às vezes, né? Então, se eu quero alguma coisa de epidemio ou de estatística, eu não preciso ficar olhando aqueles artigos de clínica, né? Acho que isso seria uma boa (...). Na área de aids, por exemplo, tem muita mistura de clínica com epidemiologia, então, às vezes, você vai por um assunto e começa a aparecer mil coisas.

Essa professora menciona um recurso lógico usado para refinar as buscas: a “interseção", revelando alguma familiaridade com sistemas de busca.

Outros pesquisadores mencionaram não ter problemas com as buscas na base PubMed/MEDLINE:

Olha, eu fiz através do PubMed, que é o principal site de busca que eu utilizo, que tem a maioria das referências, que estão em inglês". (Suely, Rio de Janeiro)

Eu falo para os meus alunos, que eu busco pela forma que me dá menos trabalho. E a forma que me dá menos trabalho é a que eu coloco no MEDLINE... eu uso muito aquele filtro de revisão e meta-análise, começo a ler as revisões. (Marcelo, Rio de Janeiro)

Nesses dois trechos do discurso, uma linguagem explicativa se apresenta, permitindo revelar segurança dos professores no uso da base de dados, inclusive na indicação aos alunos, no caso do Marcelo.

O grupo carioca é composto por vários profissionais da área de estatística e contribuem para as pesquisas desenvolvidas, orientados pelo líder da equipe, um professor que ensina a usar as bases de dados.

O grupo de São Paulo, em sua maioria, recebeu treinamento para utilizar essa base de dados e promove encontros para escrever artigos científicos, incluindo a capacitação para usar algumas bases de dados na busca pela informação bibliográfica. 
Os pesquisadores entrevistados, conscientes dessa ferramenta considerada importante pela comunidade acadêmica, procuraram deixar registrado o seu conhecimento e uso, quando questionados sobre busca de informação científica. Essa é uma maneira de reforçar o pertencimento na cultura acadêmica.

Uma das dificuldades apresentada foi a indisponibilidade de artigos de livre acesso na internet. A identificação dos artigos foi fornecida pela base PubMed, mas nem todas as revistas indexadas são de livre acesso. A finalidade da base de dados é apresentar um registro com os dados principais do artigo, como autor, título, assunto e resumo, chamados de metadados. Quando o artigo está disponível com texto completo na internet é acrescido de um campo com o link (endereço de acesso). Entretanto, somente uma parcela dos registros apresenta os textos completos, o que frustra o pesquisador que se interessa pelo artigo, mas não tem o acesso facilitado. Em estudo feito com estudantes de doutorado, concluiu-se que eles têm dificuldades em entender os conceitos de acesso aberto, autoarquivamento, copyright e os recursos com base nos acordos feitos com empresas comerciais. Isso leva à frustração e perplexidade por não terem o artigo eletrônico disponível (CARPENTER, 2012).

O mesmo sentimento de frustração acontecia com as bibliografias impressas: os artigos eram identificados, mas o pesquisador precisava localizar a biblioteca depositária da coleção da revista e, muitas vezes, precisava pagar para ter uma cópia do artigo. Entretanto, o pesquisador tinha menos expectativa de encontrar facilmente o artigo nessa época do que agora com a internet. Esse é um exemplo da relação estática e dinâmica em sistemas semióticos: a mesma situação ocorre, porém de maneira diferente. Em outras palavras, "o sistema se desenvolve, permanecendo o mesmo", como abordado em trabalho de LÓTMAN (1999, p. 12) sobre as transformações graduais e regulares na cultura.

Outra consequência decorrente da indisponibilidade de textos completos de artigos é a desistência, por parte do pesquisador, e a transferência da seleção para outros artigos, que estão disponíveis. Dessa situação decorre que os artigos disponíveis em acesso aberto passam a ser mais utilizados (KAMPF, 2012). A seleção da informação é direcionada para a facilidade de acesso, reformulando critérios de qualidade até então presentes na cultura. O Google, diferente das bases de dados bibliográficas, mostra sua missão de tornar todas as informações acessíveis gratuitamente e, assim, conquista o pesquisador que busca a facilidade no acesso. 
O sistema de signo PubMed é tradicional na cultura acadêmica biomédica e, parodiando Shakespeare sobre a rosa (Romeu e Julieta), "com qualquer outro nome teria o mesmo perfume", ou seja, significaria a organização da literatura acadêmico-científica internacional da área. Para os pesquisadores biomédicos, esse sistema de signo é amplamente mencionado na cultura: bibliotecas e portais divulgam, seus pares comentam em grupos de pesquisa, é citado em eventos científicos, entre outras formas de disseminação. Cada área de pesquisa tem seus sistemas de signos próprios, por exemplo, os psicólogos têm disponíveis bases de dados da área temática de interesse, como a Psycholit. O mesmo ocorre com os pesquisadores das áreas de sociologia, que dispõem da base Sociological Abstracts e outros casos semelhantes. As bases de dados, mesmo de diferentes áreas do conhecimento, seguem um mesmo modelo de organização, desenvolvido por outros profissionais e que se modificam com as criações e aperfeiçoamentos tecnológicos.

No caso desse grupo de pesquisadores multiprofissionais, o PubMed, embora esteja no núcleo da cultura, é um instrumento menos familiar para os membros com formação não biomédica. Há uma diferença, característica da tradição de pesquisa nas áreas, quanto à utilização de material bibliográfico, livros/catálogos e artigos de revista/bases de dados pela comunidade acadêmica científica. Os livros têm a preferência de pesquisadores das ciências humanas e os artigos, das ciências biomédicas. As bases de dados, como a PubMed, em sua grande maioria, indexam somente revistas. A seguir, são apresentados alguns exemplos de colocações relacionadas ao tipo de material bibliográfico consultado por alguns dos pesquisadores:

Hoje, basicamente, os artigos, os textos que a gente tem feito só citam periódicos ou trabalhos de congresso, cada vez mais. Tem dois livros, um livro que eu cito neste artigo, agora que está para sair (Marcos, psicólogo e professor, SP)

Você vai ser julgado num concurso acadêmico pelo tanto de artigos que você publicou em revistas de alto impacto, números de alunos de doutorado que você orientou, mas não pelo número de informações de divulgação que você fez pra comunidade ou número de sei lá artigos e livros paradidáticos, (Humhum.) é que você fez para um ensino médio, por exemplo. (Luís, médico, SP)

... na parte teórica livro, e, claro, muita aula, muito seminário, muito professor bom, fazendo a facilitação da leitura, e acho que na Antropologia, tem muito isso de você entender que aquilo que tá no livro, é a conclusão desse trabalho prático (Fátima, socióloga, SP) 
Então, mas é por conta dos temas que eu to querendo ler, e que são temas mais de fundo, mais epistemológicos (HumHum.). Queria voltar pros clássicos, tal, vontade de ler livro, preguiça de ler artigo no momento. Acho que artigo, acho que vou continuar fazendo o que eu to fazendo. (Raquel, psicóloga e professora SP).

Assim, esse pode ser o motivo pelo qual alguns pesquisadores relataram usar pouco esse instrumento, considerado um sistema de signo central na busca por informação para a comunidade acadêmica da área da saúde e periférico para comunidades de outras áreas do conhecimento.

Isso exemplifica a complexidade dos sistemas semióticos. No sistema modelizante da estrutura das bases de dados bibliográficas são criados textos geradores de sentido para determinada cultura, como a base PubMed, a base Sociological Abstracts, a base Psycholit entre outras. Esses textos são centrais nas comunidades temáticas que o interpretam (utilizam), mas são considerados não textos para aqueles que nunca tiveram contato com ele, como culturas sem acesso às tecnologias, culturas não acadêmicas etc. (IVÁNOV e col., 2003). As culturas acadêmicas são fortemente orientadas para o emissor, os textos são fechados, pouco acessíveis e, quando produzidos, são elaborados visando um leitor (usuário) ideal e específico.

Diferentemente, o Google, outro sistema de signo, é mais voltado para o receptor, porém produzido de estrutura semelhante ao PubMed. Sua utilização é mais simples e acessível, embora o acesso seja restrito aos incluídos digitalmente. Nesse caso, o texto é forçado “a aspirar a uma convencionalidade mínima” e imitará o socialmente dado, orientando-se para o tipo de mensagem que se encontra na linguagem natural (IVÁNOV e col., 2003, p.109).

A estrutura semiótica das bases de dados, antes característica da área acadêmica, amplia-se na sociedade para a população em geral, digitalmente incluída, que utiliza o Google para buscar qualquer assunto: receitas de comida, roteiros de viagem, entretenimento etc. O público leigo, em grande parte, ignora os mecanismos de busca utilizados pelos usuários das bases de dados bibliográficas, como a citada PubMed. 


\subsubsection{MeSH: um Símbolo Para Quem?}

Aprofundando a reflexão sobre as bases de dados, encontra-se outra ferramenta, utilizada de modo interconectado com a base PubMed/MEDLINE. Trata-se do vocabulário MeSH, já abordado na introdução deste trabalho como um sistema para a terminologia em saúde. Por ser um instrumento de busca, por assunto, nas bases de dados, foi mencionado nas entrevistas.

A ocorrência da palavra MeSH nas entrevistas foi baixa, apareceu somente em uma delas. O outro tesauro citado foi o DeCS, uma tradução do $\mathrm{MeSH}$, conforme abordado na introdução deste trabalho. Entretanto, de maneira indireta, as expressões "busca por assunto", "palavras-chave" ou "termos", que caracterizam familiaridade com tesauros, foram mencionadas em dezesseis das vinte e cinco entrevistas realizadas. No roteiro da entrevista não foi indagado o uso de tesauros de modo direto. O pesquisador era convidado a dizer como fazia a busca de informação para suas necessidades de pesquisa e como havia localizado os dois últimos artigos científicos lidos. Da mesma forma como ocorreu com os demais sistemas de signos aqui apresentados, dependendo do andamento da entrevista, a entrevistadora perguntava, ou não, se faziam buscas por palavras-chave ou assunto para confirmar esse uso.

O uso de tesauros não foi citado por todos os pesquisadores. Alguns deles disseram procurar por autores e palavras do título. Infere-se que eles desconhecem o tesauro como ferramenta de busca ou não o utilizam com regularidade, pois não foi mencionado espontaneamente na maioria das entrevistas.

A pesquisadora, que citou o nome do vocabulário MeSH espontaneamente, é uma psicóloga, doutoranda, do Rio de Janeiro (Dina):

A gente usa MeSH. Se eu não tenho certeza de algum indexador, eu entro no PubMed pra dar uma olhada e ter certeza de que eu estou buscando tudo que poderia aparecer.

A pesquisadora Cristina, enfermeira em São Paulo, disse usar descritores, mas houve a interferência da entrevistadora que a ajudou a se lembrar dessa palavra. Depois ela negou, dizendo não usar descritores e comentou sobre uma experiência negativa ao procurar informação usando o descritor incorreto, ou seja, no singular: 
Cristina: (...) então eu fui pegar tudo que tinha de morte e estigma também (...) peguei... é, tentava pelos, é...

Entrevistadora: Descritores?

Diana: ...também pelos descritores, fui, achei tantos artigos, aí tentava achar o artigo inteiro.

Não, mas por... porque eu não uso aquele descri...sabe, aquele que você vai lá? [Riso] Apesar de que, olha isso, olha a doida, depois de duzentos anos eu fui lá na biblioteca pegar um livro, aí eu falei pra menina: 'Olha, eu não acho nada de órfãos'. E ela: 'Olha você já foi não sei aonde? Aí então em órfãos você não vai achar, tem que ser órfão'. Aí eu falei: 'Ah tá!'. Mas intuitivamente eu usei órfão, perda dos pais, morte dos pais, e aí você pega umas coisas nada a ver...

Entrevistadora: Uma letrinha só! [Risos]

O orientador de Cristina, Professor Rogério de São Paulo, informou que usa o vocabulário controlado das bases de dados, citando o tesauro DeCS (Descritores em Ciências da Saúde). Ele comentou que recebeu treinamento na biblioteca. Esse pesquisador é considerado competente em informação pelo grupo em que atua (NEPAIDS), termo que designa uma pessoa que tem independência para usar bases de dados e utilizar as ferramentas disponíveis de modo intenso (LAU, 2006; SHENTON, 2009). Vale ressaltar que esse orientador também ensina seus alunos a utilizar as bases de dados e todos os seus recursos, sendo um multiplicador dessa competência. Abaixo, a sua fala:

Eu fui treinado por esta Faculdade quinze anos atrás, eu acho (...) eu aprendi o vocabulário controlado, o que é o vocabulário controlado (...) Eu uso o DeCS, quando estou com um tema que eu não estou conseguindo fechar, que está meio assim..., eu recorro ao DeCS para ver se o DeCS já pensou sobre o assunto. Eu vou em outros vocabulários controlados, mas geralmente eu fico no DeCS, o DeCS resolve.

Outro professor de São Paulo, Luís, comentou sobre a necessidade de saber usar os descritores corretos e disse ser uma dificuldade dos alunos:

(...) agora a experiência como orientador: eu percebo que muitas vezes não existe essa autonomia, muitas vezes falta essa autonomia da busca. Então o aluno fala: 'Não achei nada'. E você fala: 'Como que não achou nada? Não é possível!'. 'Não achei nada”, mas, às vezes, sei lá, será que usou os descritores certos? Aliás, descritor também é outra dificuldade, quer dizer, a pessoa coloca a palavra que lhe vem na mente, né? (...) se não achou o descritor correto não vai encontrar. 
O professor Marcelo do Rio de Janeiro informou que usa termo livre para as buscas e comentou sobre usar um filtro empírico, ou seja, com base na experiência que tem em selecionar referências bibliográficas. Mencionou buscar pela forma que dá menos trabalho:

Quando eu vou para o MEDLINE, normalmente eu simplesmente estou usando a palavra 'Respondent Driving Sampling' e a quantidade de artigos é enorme (...) Olha, meu filtro é meio empírico, assim, eu vou olhando (...). Eu falo para os meus alunos que eu busco pela forma que me dá menos trabalho, e a forma que me dá menos trabalho é a que eu coloco no MEDLINE...

O professor Ronaldo de São Paulo defendeu o uso da "linguagem nativa" na busca, embora considere o uso de descritores um facilitador:

É um facilitador, mas agora tem que ter um jeito de acessar isso mais fácil, na sua linguagem nativa, em uma lógica mais próxima à sua área de pesquisa, porque uma coisa é eu pesquisar aids sendo sanitarista, outra coisa é eu pesquisar aids sendo pesquisador de área básica. Então, quer dizer, o modo como eu quero acessar os artigos não é só a questão da temática em si, é o tipo de caminho pelo qual eu quero acessar, as próprias conexões...

Alguns pesquisadores têm familiaridade no uso de bases e dizem usar o vocabulário controlado, como o professor Valter de São Paulo, que disse procurar pelos termos mais específicos por serem "mais importantes para refinar a pesquisa e ir direto ao que interessa". Entretanto, quando cita um exemplo, informa que busca os termos aids e nutrição no campo de título e depois escolhe os artigos relacionados (recurso disponível em algumas bases de dados, como na MEDLINE/PubMed). Fala sobre a busca intuitiva que depende de quem conhece o tema:

(...) é a capacidade mesmo de ir cercando os temas, mas embora a gente possa consultar os indexadores, digamos que ele resolva $80 \%$ (...) dos casos, tem uma outra questão que, às vezes, precisa ter um refinamento melhor, de olhar na referência, porque, às vezes (...), você encontra artigo desde a área até uma coisa que não tem nada a ver(...). É difícil fazer uma orientação muito precisa, porque tem uma coisa muito intuitiva e isso depende do quanto a gente conhece já o tema. (...) foi um tema que, no início, eu tinha muita dificuldade, porque envolve algumas coisas de economia, de emprego, e até você achar a palavra chave adequada... O fato de ter lá nos indexadores nem sempre te ajuda tão rápido. 
A "busca intuitiva", mencionada na entrevista, é uma característica de busca dos jovens acostumados com o uso de tecnologias de informação, conforme relatado no artigo de ROWLANDS e colaboradores, 2008. Entretanto a busca intuitiva parece funcionar para aqueles que conhecem o assunto em profundidade e não para estudantes no início das atividades de pesquisa.

Outro professor do Rio de Janeiro, que também atua em São Paulo, Expedito, disse procurar pelos unitermos e comenta que há "unitermos infelizes", provavelmente referindo-se aos documentos indexados incorretamente:

(...) pelo PubMed mesmo e coloca as palavras-chaves, os unitermos, e aí vai encontrando (...) Olha coisas que eu noto assim: são unitermos infelizes, eu acho que isso ainda existe, não é? Coisas que deveriam constar como unitermos, depois que você lê o artigo não estão lá e outros que constam e o artigo não é bem sobre aquilo.

A professora Maria Helena do Rio de Janeiro informou que usa assuntos para procurar nas bases de dados, mas que tem dificuldade nesse tipo de busca:

Primeiro pra mim é o PubMed. E assim, métodos de busca: ou o assunto ou então, quando eu conheço o autor, aí eu quero ir direto, aí eu já vou no autor e já busco (...). Eu acho que às vezes a minha complicação é na busca de um assunto particular, entendeu? (...) às vezes eu coloco uma palavra e vem 500 (referências), que não são nada daquilo que eu quero. $E$ até achar algum, aí como eu que faço para encurtar esse caminho, né?, que às vezes pode ser tortuoso. Eu faço assim, escolho algum resumo que se enquadra nas minhas especificidades e aí eu ou vou naquele e vejo todos os resumos relacionados àquele ou então eu pego as palavras chaves daquele artigo e faço nova busca, porque às vezes eu sei que eu estou fazendo a busca errada e não estou conseguindo ir naquele objetivo.

A professora Raquel de São Paulo disse usar palavra-chave e relata que isso ocasiona resultados em grande quantidade:

Assim, eu entro no artigo, eu acho os autores, pego para ver lá, quatro, cinco artigos do mesmo autor, eu quero aquele artigo, ou eu faço a busca por palavra chave e aparecem lá trezentos artigos, tá certo? Aí eu vou olhando pelo abstract que tem lá ou título. 
Os demais pesquisadores disseram usar termos livres, palavras-chave ou descritores, conforme a seguir:

Então você vai pelas palavras-chave pra tentar buscar, para tentar pegar pela metodologia que as pessoas (...) (Luana, estudante, SP)

Como termo livre (...). Não apareceu muita coisa porque realmente não tem muita coisa desse tema ainda publicado (...). É, eu dei uma refinada através de alguns autores. (Suely, RJ)

Eu geralmente uso o PubMed, aquele MEDLINE, e eu uso alguns descritores. (Paulo, RJ)

Sim palavras chaves. Para esse teria que usar RDS (Respondent Driven Sampling) ou o nome de algum autor como Heckathorn, Salganik. (Amanda, RJ)

Juliana e Diana do Rio de Janeiro referiram usar palavras-chave, quando indagadas pelas entrevistadoras.

$\mathrm{Na}$ área da ciência da informação, o MeSH é um texto de cultura e importante instrumento de comunicação, usado para a indexação e recuperação da informação em bases de dados. Para os pesquisadores, o MeSH parece não ter mesma importância.

Os pesquisadores participaram de algum treinamento em bases de dados no decorrer de suas carreiras acadêmicas, portanto, devem ter tido contato, em algum momento, com os vocabulários controlados. Entretanto, observa-se que o uso de descritores não aparece na maioria das falas, seu uso não foi bem assimilado. Os pesquisadores dizem usar palavras-chave ou assunto, sugerindo terminologia e não descritores de tesauros.

Assim, o MeSH apresenta-se como um recurso subutilizado ou utilizado indiretamente pelos pesquisadores sem que percebam esse instrumento. Algumas hipóteses podem ser levantadas para justificar essa atitude, considerando os conceitos de semiosfera, como relatado a seguir.

$\mathrm{Na}$ fala que considera mais fácil fazer a busca pela "linguagem nativa", entende-se que é melhor usar linguagem natural e não a documentária. Isso pode ser devido à diversidade de áreas envolvidas nas questões de saúde pública onde se insere o tema aids. Quando o pesquisador exemplifica a necessidade de informação entre um 
sanitarista e um pesquisador da área básica, refere-se às diferenças culturais num mesmo grupo de estudo. Esse grupo, por sua vez, também se divide em diversas culturas, como os que trabalham diretamente nos serviços à população, os que atuam na pesquisa laboratorial, científica, atividades acadêmicas, entre outras. Esses grupos fazem parte da semiosfera de uma mesma cultura, a acadêmica, utilizando diferentes modelizações de linguagens, numa interação constante, gerando informação nova. Na semiosfera, há desigualdades ainda que tenha as mesmas características e há assimetria, ainda que haja certa uniformidade. "A estrutura da semiosfera é assimétrica" e torna-se aparente na relação entre o centro e a periferia (LÓTMAN, 2000, p.127).

A assimetria encontra-se expressa nas correntes de traduções internas nas quais a densidade da semiosfera é permeada. O observador pesquisador não percebe o MeSH como texto central como o observador da ciência da informação. A assimetria está igualmente expressada nos diálogos da cultura, é por meio do diálogo que surgem as informações novas. Pelas narrativas das entrevistas percebe-se a existência de regras, classificações, padrões de comportamento de busca, porém, observam-se também atitudes imprevisíveis, diferentes do esperado de um professor, estudante universitário, pesquisador. Um exemplo de imprevisibilidade é uma informação importante para o desenvolvimento de uma pesquisa chegar até o pesquisador por meio de um folheto de propaganda, ou uma obra de arte que serve de inspiração.

A terminologia de uma área do conhecimento, que vai sendo incorporada por outra, também é um evento imprevisível. O termo "resilience" foi adotado pelo MeSH em 2009, juntamente com o termo "Psychological", formando o descritor "Resilience, Psychological" para designar a habilidade das pessoas em se adaptarem e voltarem ao equilíbrio em face de tragédias, tramas e outras situações de grande estresse. Essa palavra é oriunda da física e significa a capacidade de um material voltar ao seu estado normal depois de ter sofrido tensão. A princípio os objetos são diferentes, mas o mesmo conceito pode atender às duas áreas diferentes do conhecimento.

A modelização de linguagens é percebida nas falas. As formações acadêmicas dos componentes do grupo são diversificadas, incluindo médicos, enfermeiros, psicólogos, estatísticos, sociólogos entre outros, verificando-se que as formas lógicas de busca dessas pessoas são diferentes. A linguagem documentária não é compreendida pelos pesquisadores de forma homogênea, pois cada um tem seu próprio modelo de mundo envolvido no processo. A convivência em grupos heterogêneos contribui para o 
enriquecimento de linguagens. As culturas, por meio das trocas de informações, vivem em constante processo de transformação, sendo positivo para o desenvolvimento da ciência.

Uma hipótese sobre o uso do tesauro pelo pesquisador é a forte incorporação da cultura de busca dominante do Google. Os pesquisadores fazem as buscas na base MEDLINE como fazem no Google. A busca intuitiva, a que se referem os pesquisadores no discurso, parece ser uma tendência: iniciar uma busca e ir seguindo pelos hipertextos (navegando) em buscas paralelas. Essa forma de busca, apesar de provavelmente ser desconhecida pelos pesquisadores, utiliza os descritores do MeSH para as conexões. Um pesquisador mencionou ter problemas em seguir a intuição e procurar bibliografia com a palavra "órfão" no singular, quando foi informada que o termo correto era no plural. Se ela estivesse usando o MEDLINE este problema não ocorreria porque o MeSH é acionado na busca pelos termos livres, recuperando assim os termos no singular ou plural.

Um exemplo para ilustrar essa situação: quando se digita no campo de busca a palavra aids, a estratégia de busca criada pelo sistema é: "acquired immunodeficiency syndrome"[MeSH Terms] OR ("acquired"[All Fields] AND "immunodeficiency"[All Fields] AND "syndrome"[All Fields]) OR "acquired immunodeficiency syndrome"[All Fields] OR "aids"[All Fields]. O pesquisador não percebe a complexidade por trás desse termo, mas tem o resultado que espera. Dessa forma o pesquisador não é prejudicado, porque o programa buscou pelo descritor MeSH, além do termo livre aids. É importante ressaltar que não são todos os sistemas de informação que possuem essa tecnologia sofisticada de busca. No caso em questão (MeSH e PubMed), houve transformações em novos códigos nessa linguagem artificial para acompanhar a demanda de comunicação.

Outra questão é a grande quantidade de informação disponível. O pesquisador faz o que dá "menos trabalho". Para não perder tempo elaborando estratégias de busca ou lendo manuais e tutoriais de bases de dados, o pesquisador prefere fazer buscas simples e usar a intuição para descobrir trabalhos importantes. O problema, nesse caso, é perder informações importantes que podem ficar ocultas na busca hipertextual.

Assim, revela-se um dilema do pesquisador: usar o tesauro para procurar informação investe mais tempo elaborando a busca, mas os resultados são mais relevantes. Buscar da forma mais simples, sem usar as ferramentas mais complexas (avançadas), é mais rápido, porém o resultado demanda mais tempo do pesquisador para 
ler a grande quantidade de registros recuperados. Em ambas as opções, o pesquisador vai consumir seu tempo, seja na elaboração da estratégia, seja na seleção do resultado.

O contexto deve ser observado. Os pesquisadores, quando indagados, foram livres para imaginar uma situação de busca da informação, mas sabemos que cada um deles deve ter elaborado mentalmente um determinado contexto. Em outros momentos das entrevistas foi comentado que há diferença entre buscar uma informação para completar um trabalho, como um artigo, por exemplo, e buscar informação para inspirar uma pesquisa. Nesses casos os contextos são diferentes e devem ser diferentes as formas de busca. $\mathrm{O}$ pesquisador para responder à pergunta fez uma autorreflexão ou uma autocomunicação.

A autocomunicação, abordada por LÓTMAN (2000), parte do princípio de que a mensagem a ser direcionada ao outro direciona-se a si próprio primeiramente: "nessa instância, assume-se que antes do ato da comunicação há uma mensagem conhecida por mim e não conhecida por "ele/ela"' (p.21). Esse conhecimento refere-se ao modelo de mundo, experiências e cultura.

No processo da autocomunicação, a mensagem é reformulada e adquire novo sentido a partir do contato com o mundo exterior (cultura), estimulando o monólogo interior. Assim, as respostas apresentadas pelos pesquisadores serão diferentes em outras situações, com outros entrevistadores e num contexto fora dos objetivos dos grupos de pesquisa.

E o papel do profissional da informação no âmbito dessa semiosfera em constante transformação? Essencialmente, é ajudar o pesquisador a aceder ao mundo da informação documental, ou seja, traduzir a linguagem documentária para que a decodificação seja possível e também tornar a linguagem documentária mais próxima da linguagem das culturas que a utilizam.

Para a cultura da biblioteca e sistemas de informação, o tesauro pode ser considerado um símbolo central. Um símbolo se distingue de um signo convencional pela presença de um elemento icônico, algo entre o nível da expressão e o nível do conteúdo (LÓTMAN, 2000). Para esse autor, não há definição definitiva para símbolo e cada "sistema sabe qual é o seu símbolo e necessita dele para o funcionamento de sua estrutura semiótica" (p.102-3). 
O símbolo é um importante mecanismo da memória da cultura por ser arcaico e estar finalizado, características importantes para evitar a desintegração da memória da cultura no decorrer do tempo. Ele tem natureza dupla: de um lado atravessa o pensamento das culturas e se realiza na sua invariância, repetição; de outro se "correlaciona ativamente com o contexto cultural, transformando-o e sendo transformado por ele. Sua essência invariante se realiza nas variantes" (LÓTMAN, 2000, p.104).

O tesauro está fortemente guardado na memória da cultura, remete à organização estruturada para facilitar a indexação e a busca da informação. O tesauro é tão simbólico para a cultura da biblioteca e ciência da informação, que a imagem que o representa é a de uma árvore. A imagem da árvore é polissêmica, ou seja, possui mais de um significado. Ela sintetiza o processo criativo de representação do conhecimento, uma estrutura, um símbolo como enredo. Os bibliotecários entendem esse símbolo como uma expressão sensorial do pensamento.

O símbolo da árvore é forte para outras culturas, essa figura é um signo discreto e arcaico nas culturas em geral, mas que aparece como um símbolo representando um contínuo na contemporaneidade (IVÁNOV e col., 2003). Entretanto, para o pesquisador da área da saúde, a figura da árvore não remete à percepção do tesauro. O tesauro é uma vaga lembrança de uma organização, sendo para essa cultura uma reminiscência, referência, sem associação à figura da árvore.

Uma palavra também pode adquirir o caráter de um símbolo, como as palavras: "tesauro", que etimologicamente significa tesouro, traduzido do latim, e as siglas "MeSH" e DeCS. Entretanto, essas palavras não foram citadas amplamente pelos pesquisadores.

Alguns bibliotecários informam que aprendem a terminologia usada pelos usuários por intermédio do tesauro. Conhecer os descritores e sua organização hierárquica ajuda a entender o que o usuário "procura" (recuperação) e o que o documento "esconde" (indexação). A estrutura do tesauro indica a subordinação e abrangência dos termos, facilitando o entendimento conceitual.

Para os bibliotecários, o tesauro passa das profundezas da memória para o texto e, para os pesquisadores, passa do texto para as profundezas da memória. O bibliotecário vê esse objeto como um tesouro, uma árvore do conhecimento, um 
símbolo. Exemplificando, o que ocorre num momento de comunicação entre um bibliotecário e um pesquisador, usuário da biblioteca? O bibliotecário recebe um livro e precisa indexá-lo para torná-lo acessível ao pesquisador. Nesse momento ele utiliza o tesauro, um símbolo no centro da memória para encontrar os descritores mais adequados para o livro. Num processo de autocomunicação ou semiose, os bibliotecários indexadores transformam um texto (livro) em outro (metadados) a partir de um código.

Em outra situação, o pesquisador solicita ao bibliotecário um livro sobre determinado assunto. $\mathrm{O}$ bibliotecário traduz o assunto para um dos descritores do tesauro para encontrar um livro adequado ao pesquisador, ou seja, um movimento inverso da indexação. O pesquisador está interessado no assunto do livro e não no processo de localização, o tesauro é uma mera lembrança, ele imagina que deve ter algum sistema de organização ou algoritmo. Possíveis ruídos são esclarecidos no diálogo entre os dois profissionais. Esse processo de comunicação transforma-se quando a pessoa do bibliotecário não está mais presente para dialogar com o pesquisador. Em tempos passados, as fichas catalográficas e as bibliografias impressas eram os instrumentos usados e foram substituídas pelas bases de dados e catálogos online. Como o pesquisador percebe essa transformação? 


\subsection{A INTERAÇÃO DOS PESQUISADORES COM SISTEMAS DE INFORMAÇÃO}

Todos os pesquisadores estão inseridos na sociedade da informação, possuem computadores com acesso à internet, informaram nas entrevistas que há excesso de informações e não escassez. Os pesquisadores, por estarem vinculados às universidades, têm acesso a vários sistemas de informação pagos, financiados pelas instituições e selecionados e divulgados pelas suas bibliotecas.

Conhecendo os problemas de excesso de informação, os profissionais da informação, programadores, engenheiros, inclusive bibliotecários, trabalham incansavelmente para que os sistemas de informação apresentem opções de filtros para ajudar na busca da informação relevante. São tentativas de criar recursos tecnológicos para ajudar na seleção da informação. O grande problema relatado pelos pesquisadores é a falta de tempo para fazer buscas mais proveitosas pelo excesso de atividades na sua vida acadêmica e científica.

O excesso de informação é um desafio na globalização e na complexidade das atividades acadêmicas. O objeto dos pesquisadores é a informação, que precisa ser selecionada, processada e transformada por eles e que se apresenta em quantidade excessiva, devido à proliferação de artigos publicados e diversidade de serviços de busca (ALVAREZ e col., 2007; RIFKIN, 2001).

O pesquisador precisa de tempo operacional mais longo para desenvolver suas pesquisas, tanto no contexto da descoberta quanto no contexto da justificação, quando apresenta seus achados aos seus pares e ao público leigo. Para EPSTEIN (1998), os pesquisadores deveriam valorizar mais a precisão na confirmação de seus resultados do que a pressa na sua divulgação. O que ocorre, no entanto, é uma cobrança pela quantidade e rapidez na divulgação dos resultados. Essa cobrança tem estado também no centro da semiosfera para a comunidade científica.

Alguns pesquisadores responsabilizaram as agências de fomento e avaliadores de cursos pela valorização da quantidade de trabalhos publicados em detrimento da qualidade. Essa tendência impõe a necessidade de se publicar muito. Os pesquisadores 
relatam esse fato, como a psicóloga Márcia (SP), que critica pessoas que publicam o mesmo conteúdo em mais de um artigo:

Porque eu acho que este manuseio mais devagar das coisas, ele é também bastante interessante porque você consegue aprofundar, eu acho que as coisas estão muito rápidas. Nós estamos..., então, muito rapidamente você vai tendo um excesso de informação, eu acho que está ficando cada vez mais difícil você selecionar aquilo que tem qualidade daquilo que não tem e...por causa dessa necessidade, publique, publique, publique, né? Eu não vou nem citar nomes, mas, recentemente, eu tive acesso a três artigos e os três são um só, os mesmos autores! Eu acho um absurdo isso, eu acho um absurdo! É, então você pega um trabalho, desmembra em três e, na íntegra é um só. Eu diria que é pornográfico, pra não dizer outra coisa. Então, essa é uma dificuldade, a gente tem que tomar um pouco de cuidado, né? Os limites, aí, uma coisa meio ética, né? A ética do pesquisador.

A pesquisadora reitera, repetindo palavras para reforçar o sentido. A repetição, nesse caso, tem uma finalidade didática e intensificadora para chamar a atenção da outra pessoa que ouve. A repetição é bastante comum no texto falado e traz um apelo emocional de sentido (KOCH, 2013). As palavras "três", "um só" e "ética" foram duplicadas. O ético é publicar um só artigo ao invés de três muito parecidos.

A socióloga Fátima (SP) criticou a grande quantidade de publicações com pouca reflexão teórica, que caracteriza a área acadêmica na atualidade:

Porque eu acho o contrário, a minha critica é ao contrário, o que existe hoje na Academia eu sou completamente contra, entendeu? Porque o cara faz uma pesquisa, ele é obrigado a publicar, ele é obrigado a titular, ele é obrigado a ter não sei o que de produção. Isso é uma babaquice, entendeu? Porque Freud, Lévi-Strauss, nunca teriam passado, eles não seriam nada com o esquema acadêmico de hoje. Porque eu, eu acho que tem grandes obras, que demoram dez anos para ser escritas, né? Eu acho que tem grandes reflexões, que são sólidas. Eu sou muito da linha francesa nesse sentido, né? Não gosto dessa babaquice americana, desse modismo. Então é pobre, é superficial, é óbvia, é uma poluição. Pra que entrar na internet, no... no... sei lá, no Google Acadêmico, né? Tem sessenta pesquisas de campo estudando coisas parecidas. É lindo no Congresso, é lindo pra movimentar o Brasil, mas teoricamente isso é uma babaquice, é melhor ter duas e fazer uma reflexão profunda, do que isso...

Notam-se, nesse último discurso, as repetições e gírias, indicando uma linguagem emocional. Palavras como "obrigação", "contra" e "babaquice" indicam imposição, reação e opinião. Essa pesquisadora completou seu discurso com crítica 
sobre o formato rígido imposto pelos editores de revistas ao autor de artigos, que limitam a criatividade:

Então, não tem, eu acho que é uma pobreza, é uma pobreza de criação, porque se, eu acho assim, se tudo ta formatado, desde a regra da ABNT até a tese, até a forma que você tem que concluir, apresentar o dado e a tabela, isso não é por acaso, entendeu? Não é só o formato, o que tá escrito também acaba sendo formatado, empobrecido.

Ela informa guardar frases em arquivos de texto para usar os "chavões" ao precisar escrever artigos:

...eu tenho um arquivo em Word, de chavões: de representação, num sei quem, página tal; quantitativo, página tal; grupo focal, faz uma bola de neve, que eu nem sabia que tinha esse nome de indicar alguém, página tal; porque supõe que você pesquisou, leu para fazer, mentira, mentira, né?

Em seguida, menciona que a internet contribui para a pesquisa, porém facilita as irregularidades e plágio:

Eu acho que pode ter, por exemplo esta questão da Internet, facilitou o mundo, né? A vida de todo mundo (...) Eu acho que a Internet, ela é uma grande modificação, agora conforme veio essa babaquice formatal, você faz copia-e-cole, pra atender. Então, por exemplo, 'Introdução para gravidez na adolescência' pra artigo sobre 'vulnerabilidade jovem', eu tenho já um monte lá, eu mudo a ordem, porque todo, eu tenho que por a introdução, justificativa com não sei quantas páginas. Então, pronto, eu tenho, papapapa. Eu não vou pensar aquilo de novo porque aquilo é óbvio, até Cristo sabe. Pelo amor de Deus! Então, essas coisas eu acho pobre..."

A formatação a que a pesquisadora se refere é um modelo de estrutura tradicional para a escrita científica, exemplificado por ela com algumas partes: introdução, justificativa, quantidade de páginas. Para a semiótica, trata-se de uma linguagem secundária, um texto cultural, que está em conformidade com as normas da época, da geração e do grupo social; no caso, a cultura acadêmica (IVÁNOV e col., 2003). A crítica da pesquisadora dirige-se às normas acadêmicas. Os estudos de Lótman tratam sobre a ideia do empobrecimento da cultura quando ocorre o enrijecimento estrutural, dificultando o seu dinamismo (AMÉRICO, 2012). O texto é criado individualmente e só é guardado na memória da cultura se for aceito pelo coletivo, protegendo a cultura da abundância incontrolável de novos textos. Quando a cultura alcança maturidade estrutural, como a acadêmica, por exemplo, surge a necessidade de autodescrição da criação, ou a criação de seu próprio modelo. Isso torna a organização 
mais rígida, excluindo os textos que não se encaixam no modelo da cultura e canonizando aqueles que obedecem ao modelo rígido. $\mathrm{O}$ enrijecimento empobrece a cultura e perde-se o dinamismo ou mecanismo propulsor. Em resposta a esse processo, ocorre um deslocamento dos textos da periferia para o centro da cultura, iniciando novamente o processo num movimento constante.

Associando os termos "texto formatado" à "pobreza de criação", abordados pela socióloga Fátima, sugerimos a aproximação da sua opinião com esse pensamento de Lótman. Há uma saturação no modelo estrutural provocada com a contribuição das tecnologias, como os programas de computador criados para formatar artigos e papers. A reação da cultura está ilustrada na colocação da socióloga. Com a internet, ela considera que ficou mais fácil "formatar", pois, é possível recuperar trechos de livros e usar o recurso de copiar diretamente para o trabalho no momento da citação.

O assunto "formatação" ou estrutura do texto científico tem sido explorado pela literatura. A lógica da estrutura visa facilitar a comunicação dos achados do pesquisador aos seus pares e leitores. O leitor, mais do que o parecerista, precisa entender o objeto e as conclusões do pesquisador para aceitá-lo na comunidade científica da área (VOLPATO, 2007). Todavia, um estudo divulgado recentemente abordou o lado negativo da estruturação rígida de artigos, que engana pareceristas e leitores (VAN NOORDEN, 2014). Esse estudo relatou a proliferação de aplicativos na internet, que geram papers automaticamente a partir de alguns dados falsos inseridos pelos interessados em submeter seus trabalhos. Os papers, gerados no formato padrão de revistas científicas, foram irresponsavelmente submetidos a revistas especializadas e foram aceitos por algumas delas. Esse tipo de fraude tem sido cometida há mais tempo, até mesmo por cientistas renomados como SOKAL e BRICMONT (2001), que após submeterem um trabalho falso para uma revista de ciências sociais, escreveram um livro para criticar alguns teóricos citados.

A saturação do modelo e as divergências ocorrem na cultura e, assim, os pesquisadores precisam de mais tempo ainda para desenvolver suas atividades. $\mathrm{O}$ professor do Rio de Janeiro, Expedito, criticou a pesquisa publicada em várias partes, dificultando o entendimento na sua totalidade, que ele chama de "artigo salame". Essa forma de divulgar a pesquisa visa a atender revistas que limitam o número de palavras e a aumentar a quantidade de artigos para o autor. Entretanto, dificulta a vida de outros pesquisadores, como esse professor, que disse necessitar de mais tempo para ler e fazer 
pesquisas, além das atividades administrativas, que aumentam cada vez mais. Mencionando as palavras por ele proferidas: há uma "burocracia muito grande". A burocracia, estrutura organizativa caracterizada por regras e procedimentos regularizados, está no núcleo da cultura e forma um conjunto de textos rígidos que empobrecem a criação.

Nesse contexto de cobranças para publicar, resolver questões burocráticas, avaliar trabalhos científicos, além de promover pesquisas, o pesquisador precisa priorizar atividades para atender tantas demandas e, sobretudo, aprender a administrar melhor o tempo (VOLPATO, 2009). A tecnologia foi desenvolvida para ajudar também a economizar tempo das pessoas e os sistemas de informação são organizados para tornar as buscas por informação mais rápidas.

Aprender a usar o potencial da informática é uma forma de não desperdiçar o tempo (VOLPATO, 2009). As bases de dados e seus tesauros, quando passaram para o código digital facilitaram a busca da informação. As antigas versões impressas eram organizadas por índices de autor e assunto, levando o pesquisador a folheá-las segundo a ordem alfabética, o que demandava muito trabalho e tempo. $\mathrm{Na}$ versão digital, o pesquisador digita uma palavra e algoritmos recuperam os registros que trazem a palavra, esteja ela no meio de um título, descritor, autor etc. O raciocínio lógico da ordem alfabética não é mais necessário na busca digital, houve uma transferência dessa atividade para o computador, que tornou a busca mais rápida. Por outro lado, a busca digital recupera mais registros porque procura a palavra digitada numa área de maior abrangência do que os antigos índices.

Nos relatos das facilidades e dificuldades no uso dos sistemas informatizados para buscar a informação, foi possível observar como o pesquisador percebe a mudança do meio impresso para o digital.

O professor Ronaldo recorda-se de quando fazia buscas nas bibliografias, chamadas por ele "base de papel", no caso, referindo-se ao Index Medicus:

É, e mesmo aquilo que está em base de papel você localiza muito mais rápido, e consegue, chega à sua mão muito mais rapidamente. Lembro, no tempo que eu fiz doutorado não tinha, era uma dificuldade, às vezes você não conseguia localizar onde tinha o negócio, se localizava você tinha que entrar em contato com a biblioteca, você mesmo, a biblioteca tinha poucos sistemas de relação entre elas. Hoje em dia você entra em qualquer unidade da Universidade e você acessa todas as outras. Essa é a grande facilidade e essas bases, que agora estão colocando os artigos 
on-line na integra, isso dá uma facilidade. O SciELO é uma benção, (risos), é um “cielo”...

Alguns professores solicitam aos alunos, estagiários e secretários que façam as buscas para eles, por não terem tempo. Essa colocação pode ocultar uma dificuldade na utilização dos sistemas de busca, que se atualizam rapidamente e demandam tempo para aprender as novas ferramentas. O Prof. Expedito, do Rio de Janeiro, expôs a situação de forma bastante humorada:

(...) dizem que eu sou um velho folgado, que eu faço muito e quando eu preciso eu... tenho [Risos] Eu sei que uma pessoa é especialista numa coisa, eu mando e-mail que diz: 'Me mande referência sobre tal coisa'. Isso eu tenho feito demais. [Risos] Às vezes eu ponho: 'Obrigado por este ato de piedade cristã'

Outra professora do Rio de Janeiro, Maria Helena, também disse que pede para estagiários. Ela informou que tem experiência e usa os serviços de estagiárias para localização dos trabalhos.

A médica de São Paulo, Lia, disse não ter tempo de se atualizar por meio de leituras por trabalhar na área de prestação de serviços e ter muita atividade e, por isso, solicita ajuda ao bibliotecário:

É, porque eu, como eu falei, isso é um serviço, a gente tem um monte de serviços de rotina, um monte, um monte. Então tem um monte de coisas que eu gostaria de ler e eu não leio, não é porque eu não tenho acesso, é porque eu não tenho tempo. Aí eu fico assim, sei lá, pensando se os serviços deviam destinar um certo período para isso. Mas isso quem trabalha no serviço pensa sempre. (...)Nós não buscamos nada, eu peço para a bibliotecária, ela busca para gente.

O uso da repetição das palavras "serviço" e "monte" pretende convencer a outra pessoa do diálogo (entrevistadora) da justificativa da solicitação da ajuda da bibliotecária. Numa interpretação linguística, a repetição tem função argumentativa e emotiva, nesse caso.

O médico Tiago, de São Paulo, parece não gostar das tecnologias, ele diz usufruir pouco do que as tecnologias têm para oferecer:

É, é muito engraçado. É, é a mesma história que acontece com o celular, a gente fica falando assim que a gente não sabe viver sem celular, só que isso, dez anos atrás eu só tinha telefone em casa, eu não tinha celular. E ninguém morreu por causa disso, mas a gente acha que o mundo é desse 
jeito. Quer dizer, a gente faz umas certas adaptações, que é assim mesmo, né? (...) Às vezes eu acho que a tecnologia até avança, mas eu não usufruo, tem isso, tenho um pouco essa postura, ela vai até aqui, mas meus valores, meu estilo...

Esse médico aborda a questão da transformação do telefone fixo em telefone móvel e a rápida dependência da sociedade nessa modelização. Quando diz, que "ninguém morreu" porque não tinha um celular, refere-se, generalizando, que a tecnologia não é assim tão imprescindível, pelo menos para manter a vida. Como médico, a vida se sobrepõe à tecnologia, ainda que a sociedade considere o contrário em alguns contextos. POSTMAN (1998), por exemplo, aborda a questão do culto à tecnologia e como as novas tecnologias se sobrepõem às antigas, afetando os costumes das pessoas na sociedade, como é o caso do telefone móvel.

Os sistemas de signos centrais da cultura se transformam, impõem-se na cultura, mas encontram a resistência de alguns indivíduos, como esse médico, que mostrou que a interferência do signo é fraca para as suas necessidades. Faz parte da dinâmica da cultura o desenvolvimento gradual ou explosivo, para garantir a continuidade e inovação, a tomada de consciência e a transformação da memória (LÓTMAN, 1999).

Alguns pesquisadores não têm dificuldade com as novas tecnologias para busca de informação, como a pós-graduanda Cristina de SP, que informa sobre uma forma própria de organizar e guardar os arquivos digitais no computador:

Cristina: Não, eu guardo tudo, aí eu leio. Aí tá lá minha pastinha organizada, né? Por exemplo, 'morte', aí eu vou lendo, aí eu ponho lidos e úteis.

Entrevistadora: Gente, como você é organizada!

Cristina: Aí eu vou separando...

O professor Luís, de São Paulo, acredita que os estudantes mais inexperientes têm dificuldades em usar bases de dados, apesar de terem facilidades com as tecnologias, pois, eles desconhecem alguns recursos da lógica de busca, como os operadores boleanos e o uso de descritores, já citado no capítulo anterior deste trabalho:

Mas eles não sabem, não sabem. Não sabem separar muito bem a interseção da união, do que é o E, o que é o OU. Se você coloca uns parênteses, que, na verdade, você faz interseção daqueles parênteses com aquela outra coisa (...)

É lógica, eu percebo que falta um pouco de formação nessa área e isso dificulta, né? Porque o que pra gente, às vezes, parece tão fácil, né? Ou 
até mesmo pra montar um banco de dados ou pra analisar um banco de dados, que também é pesquisa, né? E você tem lá as suas variáveis e aí você quer aqueles que tem a variável $A$, mas não tenha a variável $B$, mas tem a variável $C$, pra fazer um subconjunto daquilo lá. A pessoa tem dificuldade em elaborar esse caminho pra chegar naquele subconjunto.

Esse professor informou que os bibliotecários ministram cursos sobre o uso de bases de dados aos alunos de graduação. Ressaltou que os alunos não conhecem as facilidades oferecidas pelos sistemas de recuperação da informação, justificando e elogiando os referidos cursos. O segundo parágrafo com a fala do professor indica um caráter didático, explicando de forma lógica como deve ser elaborada uma estratégia de busca nas bases de dados.

O professor Rogério, de São Paulo, relatou que conhece os sistemas de informação:

Eu frequentemente faço revisão de literatura pelos mais variados motivos, mais para as minhas pesquisas em aids. (...) Eu tenho alguns mecanismos que eu uso lá no ISI também, que me mantém relativamente informado. Eu pedi, tem lá algumas estratégias de busca que eu deixei que eles me notificam o que é que tem de novidade ou sobre algum autor ou sobre algum assunto.

Quando indagado sobre metabuscadores, ele disse gostar muito:

Adoro. Não sei se dá pra acreditar neles, né? Porque a gente não sabe o que está acontecendo por detrás, qual é o algoritmo que está por trás fazendo as coisas, mas por fim, gosto... Pra mim funciona. Acho que ele, como eu tenho uma necessidade muito focada, eu não preciso ter a segurança de que ela seja exaustiva essa busca, mas que as principais coisas tenham vindo. Então eu gosto bastante. Gostava muito do WebSPIRS quando eu fazia essa busca mais organizada.

Metabuscadores são combinações de vários mecanismos de busca (metasearch engine), excluindo repetições, rastreando diferentes bases de dados e proporcionando uma abrangência maior (FERNEDA, 2006). A partir de uma única estratégia, um metabuscador possibilita que ela seja aplicada em diversas bases de dados, com suas ferramentas próprias, mas que se comunicam por algoritmos com a ferramenta principal. Os metabuscadores são considerados facilitadores porque evitam a elaboração duplicada de estratégias em bases de dados diferentes. Convém observar que foi possível identificar o conhecimento dessa ferramenta pelo pesquisador, quando comenta as limitações do metabuscador: “a gente não sabe o que está acontecendo por detrás". 
Reforçando as facilidades no uso das tecnologias, o médico e pesquisador do Rio de Janeiro, Dirceu, disse que usa a informática plenamente na sua rotina de trabalho e cita a biblioteca, enquanto ambiente físico, como última etapa de busca:

Dirceu: Sou um adido de informática e de internet. Então, eu trabalhando com os laboratórios. Como eu trabalho numa universidade eu tenho acesso àquela nossa página do... como que é o nome?

Entrevistadora: CAPES?

Dirceu: CAPES, e tenho acesso também à outra página, outra biblioteca que se chama IMA, www.ima.org, que é um acesso pago, mas que é pago por um laboratório que me ofereceu há muito tempo. E aqui eu uso também... eu uso bastante a nossa biblioteca. Por quê? Artigo que eu não encontro no $A, B$ ou $C$ eu pego no Comut. Então, eu não tenho dificuldade de acessar nada. A técnica de ler eu tenho, eu aprendi aqui, que a gente tem uma técnica de ler e fichar as coisas. Então, basicamente, eu uso informática pra tudo.

Ele cita a biblioteca como prestadora de serviço (Comut) e como portal da internet, relacionando a biblioteca (CAPES, IMA) com as tecnologias.

Sintetizando o que foi salientado a respeito da busca de informações nos sistemas informatizados, convergimos ao ponto de influência das novas tecnologias de informação e comunicação para os pesquisadores.

Cada aspecto apresenta um lado positivo e um negativo. Falta de tempo para o pesquisador, mas a internet abreviou o tempo para recuperação da informação. Há um excesso de informação disponível, mas foram desenvolvidas ferramentas para selecionar a melhor. É mais fácil ocorrer fraudes na internet pela possibilidade de copia-cola, mas igualmente fácil é localizar a fraude e o fraudador. A possibilidade intensiva de comunicação dificulta a vida levando ao estresse, mas ameniza a ansiedade em muitos casos. Poderíamos discorrer com mais exemplos e chegaríamos ao mesmo ponto. Essas colocações sustentam que a tecnologia tem um papel desencadeador de desenvolvimento cultural nos sistemas complexos.

A tecnologia, na forma de sistemas semióticos, ultrapassa a fronteira (semiosfera) e modeliza os sistemas vigentes na cultura. $\mathrm{O}$ extrassistema interage com o sistema numa relação "entre estática e dinâmica" (LÓTMAN, 1999, p.11). O sistema permanecerá o mesmo, mas se desenvolverá com a tradução de linguagens. As atividades dos pesquisadores continuam as mesmas: escrita, busca de informação, 
reunião com grupos de pesquisa, preenchimento de formulários etc. Porém, em contato com a tecnologia, essas atividades são procedidas de forma diferente.

As mudanças na cultura ocorrem em processos graduais ou explosivos (conceito filosófico, não físico), segundo LÓTMAN (1999). O progresso gradual é contínuo e previsível. O progresso contrário é o imprevisível, ou seja, as mudanças são mais radicais, "explosivas". Os dois processos coexistem na cultura, um dependendo do outro. O processo explosivo realiza-se num "complexo diálogo dinâmico com os mecanismos de estabilização" (LÓTMAN, 1999, p.19).

O desenvolvimento das técnicas faz parte dos processos graduais "dotados de uma potente força propulsora" e estimulados pelas necessidades práticas. As maiores ideias científicas e artísticas têm "origem similar a uma explosão" (LÓTMAN, 1999, p.20). Nos processos graduais há momentos explosivos de intensa imprevisibilidade, que muda a direção dos acontecimentos e demanda uma reformulação desde o passado.

\section{Imprevisibilidade}

Para analisar o conceito de imprevisibilidade na semiótica da cultura será feita uma simplificação com base nos resultados das entrevistas e, em seguida, algumas associações de conceitos da mesma natureza.

Identificou-se nas falas dos pesquisadores a possibilidade de encontrar informações de modo imprevisível e de forma não convencional por meio de busca em bases de dados. A imprevisibilidade ocorre no momento do encontro e processamento da informação nova pelas mentes da cultura.

O pesquisador Ronaldo, professor de São Paulo, considerado um teórico importante no grupo do NEPAIDS, indicou como acha mais conveniente buscar a informação bibliográfica:

Tem uma coisa que eu acho que é muito do cotidiano e (...) muito útil, que é a bibliografia que você vai rastreando secundariamente, então você vê um trabalho, ai aquele trabalho é de certas pessoas, ai você acha interessante aquilo, vai atrás, ou você está em um encontro e alguém cita um trabalho e você anota e já vai atrás.

Quando ele fala em "rastrear secundariamente" indica que não encontrou a informação na primeira possibilidade, mas que se permitiu seguir por outros caminhos, 
considerando essa "técnica" muito útil. Em outro momento, aborda novamente o assunto:

Uma citação até no PubMed mesmo, mas aí tem aquele link das obras relacionadas, aí você clica alí e vai. E, às vezes, uma coisa que eu faço também eu tenho um autor que tem um título que parece interessante e eu vou e dou um Google no autor, aí eu quero pegar mais transversalmente coisas que ele publicou, indexações diferentes, ou citações dele.

Nesse caso, as obras relacionadas são as indicadas pela base de dados PubMed como "artigos relacionados". O sistema faz combinações com base nos descritores da referência do artigo selecionado e cria um novo resultado com essas estratégias. É uma ferramenta bastante útil, tornada possível com o desenvolvimento das tecnologias de busca.

Para buscas de sustentação da teoria, ele indica o rastreamento espontâneo da literatura e não as buscas sistemáticas em bases de dados:

(...) eu acho que era aquilo que eu estava falando, que eu acho que é fundamentalmente pelo rastreamento informal; a literatura que você vai rastreando. Às vezes, especialmente quando eu vou começar mesmo, talvez menos ligado à pesquisa e mais ligado ao ensino. Quando eu vou começar algum curso eu faço uma 'certa rastreada' para ver se tem alguma novidade, alguma coisa assim. Mas a própria natureza do conhecimento teórico é um amadurecimento mais lento, então você vai rastreando isso meio espontaneamente. Dificilmente nessas buscas, assim, se acha coisa exatamente nova.

Novamente a palavra "rastrear" é apresentada. Esse verbo indica buscar pistas, investigar, sendo uma ação mais adequada para a descoberta de informação nova do que as buscas sistemáticas, traduzidas como fechadas e realizadas a partir de uma única estratégia aplicada na base de dados, sem desviar da linha do resultado.

A psicóloga Daniela, de São Paulo, afirmou preferir usar as informações citadas em trabalhos de evento e consultar as bibliografias dos trabalhos mais pertinentes, além de procurar por autores conhecidos e preferir essa busca menos sistemática:

(...) daí, à medida que eu vou achando esses textos, identificando no que eles referem de bibliografia, ou, às vezes, fazendo uma coisa do tipo: achei um pesquisador no Peru, que é o cara que está trabalhando para UNAIDS com essa população, vou e dou um Google no nome do cara para tentar achar tudo que ele já fez, no que ele pode estar relacionado. Então acaba sendo, acho que uma busca pouco sistemática, mas que me 
dá a sensação, na maior parte das vezes, de que hoje em dia é difícil alguém trazer uma informação sobre essa população que eu exatamente não tenha visto, ou tenha uma ideia de quem é ...

A frase "vои e dou um Google" é mencionada da mesma forma nas entrevistas, marcando esse signo na cultura. Daniela completa, considerando que essa forma de buscar bibliografia tem funcionado para atender às suas necessidades:

Eu acho que ela tem funcionado porque ela acaba me dando esta sensação de que eu estou conseguindo formar uma rede para entender quem está trabalhando nesta área, quais são as perspectivas. Da minha experiência também eu acho que este tipo de estratégia funciona, mas ela funciona melhor se em paralelo eu estou escrevendo. Então eu comecei a fazer um pouco isso para esse projeto, mas em função de várias outras atividades, que eu estou envolvida, não consegui levar muito adiante. A minha sensação é, a medida que você está escrevendo e vai identificando do ponto de vista lógico, assim, como é que eu justifico agora essa preocupação? E em tal questão quem é que respondeu? À medida que eu vou fazendo isso, tentando construir um texto que justifique entender a problemática, que eu estou trabalhando, para mim funciona melhor a pesquisa bibliográfica associada a este processo.

O caso dessa psicóloga permite identificar a sequência de seu raciocínio na construção de um texto: vai associando a busca bibliográfica ao construir um texto e detectando a falta de informações específicas para completar uma ideia, identifica lacunas. A formação de rede a que refere é uma metáfora na formação da criação. $O$ pesquisador está construindo o seu objeto, tecendo-o, vai revelando-se opaco e desconfigurado e, conforme encontra outros autores com objetos semelhantes, preenche as falhas de raciocínio e novas criações vão surgindo. Esse processo ilustra o conceito teórico e abstrato da semiose e da autocomunicação abordados por LÓTMAN (2000). As cadeias interpretativas vão se formando, enriquecendo-se com as trocas dialógicas entre a mente e os textos criados por outras mentes. E a imprevisibilidade faz parte desse processo.

A professora do Rio de Janeiro, Diana, disse usar essa mesma forma para buscar informações, nomeando-as de "buscas mais erráticas". Ela informa que orienta seus alunos a buscarem de forma sistemática em algumas bases de dados e depois seleciona os conteúdos. Abaixo está o diálogo entre as entrevistadoras e a pesquisadora:

Entrevistadora 1: Você mesmo não tem feito busca assim?

Diana: Eu faço, mas eu diria assim, a minha preocupação é que se eu que estou fazendo um projeto e eu quero caracterizar que aquele projeto 
foi baseado numa busca, como se eu criasse, a gente faria uma dinâmica, onde eu conseguiria, faço até uma etnografia dessa busca, [humhum] Essa eu encomendo. O que é obvio, que vai, vai prescindir de buscas mais erráticas, eu diria assim, mas que não estariam... A minha preocupação é criar um sistema que eu possa dizer que foi feito um levantamento dessa e dessa maneira, eu achei isso (...) E eu queria fazer uma revisão bibliográfica sobre isso, então eu defini isso, contratei uma pessoa, um estudante, falei pra ele: 'Você vai olhar no Scielo, MEDLINE, no Sociological, vai usar essas palavras-chaves, vai fazer um caderno de campo de tudo que você está achando e você vai sistematizando tudo desse e desse jeito'. Então eu fui acompanhando, dizia pra ele o que ele tinha que fazer, ele me mostrava o produto e eu ia, só que a gente tem que melhorar aqui, a gente tem que fazer um filtro aqui, a gente tem que fazer aquilo lá. Isso vai gerar uma seleção.

Entretanto, ela indica realizar "buscas erráticas", quando a entrevistadora propositalmente provoca esse tema. Houve hesitação para justificar o que seria "errática":

Entrevistadora 2: Então o que você chamou de busca errática corre por sua conta, então?

Diana: Isso, mas quando eu falo errática, [Não, eu sei] se eu entregar isso... É óbvio que se eu estou com aquele tema na cabeça, eu olho alguma coisa que tem a ver, eu olho uma bibliografia que eu acho que tem. Eu vou complementando, mas a minha preocupação é de formar pessoal. Formar pessoal e ver se eu to afirmando, eu fiz uma revisão bibliográfica eu tenho que dizer como eu fiz, porque como eu fiz vai influenciar um produto. [Claro, claro]

Entrevistadora 2: Por isso que eu separei, porque o que ela chama de errático, na verdade tem muito pouco de errático. E evidentemente ele está baseado numa experiência pessoal num background rico.

Diana: Por exemplo, era um fórum que discutia os desafios da prevenção nesses países de língua portuguesa. Como é um artigo, to dizendo assim, porque eu estou usando essa lógica, porque eu tenho adotado nos últimos tempos até porque como a tendência é cada vez mais você trabalhar em equipe e dividir, você não faz o campo, você não faz a revisão, você divide.

Identificam-se diferentes modalidades de estratégias nas narrativas. Por um lado, estão as buscas sistemáticas, interpretadas como mais fechadas, com uma estratégia definida e que apresentam resultados a serem consultados na sua totalidade. Esse tipo de busca pode ser elaborada por qualquer pessoa e não necessariamente pelo pesquisador. A ele cabe orientar as pessoas que executarão as buscas nas bases de dados, sejam 
alunos, bibliotecários, estagiários, secretários. Por outro lado, estão as buscas por eles nomeadas de "rastreadoras", "erráticas" e "relacionadas"; que são abertas, "intuitivas" e consultadas aleatoriamente como é conhecida a "navegação" na internet. Para esse tipo de busca, os pesquisadores mencionam ser necessária a experiência na temática para atender demandas pessoais. A hesitação nas falas pode ocultar a dificuldade em definir e explicar esse procedimento.

O professor Marcelo, do Rio de Janeiro, considerado expert em buscas pelos seus pares, mencionou a "revisão sistemática", afirmando que não precisa procurar por informação, elas chegam até ele:

Porque eu... a não ser que eu faça revisão sistemática e meta-análise, no fundo, eu não consulto muito as bases, entendeu? Eu sou muito mais uma pessoa invadida pelas informações do que uma pessoa que busca informações. Eu busco muito pouca informação. Ontem, eu busquei porque eu estava querendo resolver um problema prático, mas às vezes eu passo semanas inteiras sem buscar informação nenhuma, simplesmente porque eu não consigo nem dar conta.

Ele também cita as buscas sistemáticas e, em seguida, narra uma situação que considerou uma coincidência. Abaixo, as frases por ele colocadas:

Na verdade, eu, eu acabei fazendo uma busca de um tópico que eu estava querendo entender na prática o que tava acontecendo e bateu com o uma... um suplemento de uma revista que eu havia recebido de presente, então houve uma coincidência entre o que eu estava buscando e o que eu tinha na minha casa só que não tinha lido. O que eu estava querendo ver... quais eram as dificuldades que as pessoas estavam enfrentando para implementar o RDS com usuários em países variados. Então, eu estou tentando sair um pouco dessa coisa americana, que é sempre diferente da nossa, e estou indo mais para os países em desenvolvimento; então estou lendo artigo sobre leste europeu, sobre Ásia, sobre... Está me ajudando muito, mais do que propriamente os artigos americanos.

Os pesquisadores mencionaram encontrar informações importantes ao acaso e nomearam essa situação de: "rastrear bibliografia", "formar uma rede", "buscas erráticas", "buscas relacionadas", "coincidência".

Estudos na ciência da informação têm tratado sobre essa situação como serendipidade na busca por informação em bases de dados. Alguns autores mencionam a importância de se envolver com o tema e estar aberto para descobrir outros caminhos e possibilidades de encontrar informações relevantes (FOSTER e FORD, 2003; NUTEFALL e RYDER, 2010). 
$\mathrm{Na}$ literatura acadêmica, o conceito de serendipidade tem sido atribuído à habilidade de fazer descobertas a partir de situações acidentais ou pelo acaso. MORIN define serendipidade como a "arte de transformar detalhes, aparentemente insignificantes, em indícios que permitam reconstituir toda uma história” (2004, p. 23). Quando as pessoas estão envolvidas com um objeto de estudo e se deparam com acidentes no percurso da pesquisa ou situações imprevisíveis é o momento provável de ocorrer uma criação, uma ideia nova, uma luz. O pesquisador precisa estar preparado e ter tempo para reflexão para que a serendipidade possa trazer mais conhecimento (CONSOLARO, 2014).

Esse é o caso dos pesquisadores sêniores, que participam de grupos de estudo, recebem alertas, são pareceristas de revistas científicas, têm interesse em se manterem atualizados e, portanto estão no centro semiótico da sua área. Dessa forma, é provável que, as informações que procuram, estejam mais próximas do que esperam, só é preciso estar alerta para que ela se revele.

Uma questão que se coloca é o quanto a informatização dos sistemas colabora para a ocorrência da serendipidade, uma vez que possibilita as trocas e armazenamento de informações com maior velocidade e alcance. A partir das técnicas bibliotecárias realizadas no registro de um documento em bases de dados, por exemplo, é possível "navegar" por outros registros (artigos relacionados) e encontrar novos enfoques, novos sujeitos, enfim, novas informações. Para CONSOLARO (2008) a informática e a serendipidade se relacionam: "a serendipidade representa uma poderosa ferramenta mental de raciocínio e lógica que se estende cada vez mais e se enquadra na informática como um recurso de busca e resgate de informação, embora possa parecer quase impossível superar o cérebro humano neste quesito" (p.24).

Lótman, em sua última entrevista no ano de 1993, considerou que as tecnologias fazem o previsível, mas o homem desenvolve algoritmos que proporcionam a possibilidade da imprevisibilidade nas tecnologias (AMÉRICO, 2012). De uma maneira simplificada, podemos dizer que a tecnologia é o meio e não um fim.

Os sistemas digitais são novas modelizações criadas na cultura, que acabam contribuindo para as transformações na mesma cultura. Foi possível assim perceber com base nos relatos dos sujeitos da cultura nesta pesquisa. Seja com dificuldade, ou facilidade, para interagir com os sistemas informatizados de busca, os pesquisadores precisam entender os códigos que se modelizam. A linguagem documentária e a 
linguagem de busca dos programas de computação demandam traduções a partir dos códigos não coincidentes, que resultam em novas modelizações e vão se transformando infinitamente.

A leitura, ação anteriormente feita com a luz sobre o papel, hoje se processa com a luz atrás da tela. O livro palpável, analógico, pode ser lido em tela. Ainda se observa a escolha pela leitura em papel por muitos pesquisadores. Outras modelizações estão transformando também o formato tradicional do livro na tela para outras possibilidades de mídia, que podem acompanhar o texto escrito, como som, filmes, figuras. Na cultura acadêmica, todavia, ainda predomina o formato tradicional de escrita linear, ou seja, está orientada em direção aos modelos discretos de linguagens formalizadas, característica linguística desde a primeira metade do século passado. Essa característica vem sendo substituída na sociedade por uma preocupação com os textos contínuos, indecomponíveis, que têm adquirido maior significância (IVÁNOV e col., 2003). Exemplo disso é a proliferação de arquivos de filmes no Youtube, site que permite que seus usuários carreguem e compartilhem vídeos.

A área acadêmica é reconhecidamente voltada para inovações e a mente dos pesquisadores deve estar sempre alerta para traduzir e, assim, criar novas linguagens e possibilidades para manter e transformar a cultura e a natureza. As estruturas rígidas e nucleares dessa cultura tendem a movimentar-se consolidando a dinâmica e irregularidade semiótica. A importância das tecnologias está centrada no aumento do conhecimento metalinguístico.

O conceito de imprevisibilidade desenvolvido por Lótman se aproxima da ideia de serendipidade, embora seu foco esteja nos estudos dos sistemas semióticos. LÓTMAN (1998) defende a imprevisibilidade nos estudos científicos em contraponto com as ligações de causa-efeito. Ele buscou no químico russo Ilyá Prigogine a base para explorar sua ideia.

Ao investigar os processos irreversíveis na física e química, Prigogine chegou a conclusões teóricas de interesse para todos os processos que ocorrem em situações de equilíbrio e desequilíbrio. Os primeiros transcorrem fluidamente, submetendo-se às leis da causalidade em trajetórias reversíveis (simétricas). Nos processos de situações em desequilíbrio aparecem os pontos de bifurcação, que transcorrem em duas ou mais direções sem a possibilidade de previsão. Nessas condições aumenta bruscamente o papel da casualidade. LÓTMAN (1998) concluiu esse raciocínio dizendo: 


\begin{abstract}
A introdução do fator casual no mecanismo da causalidade representa um enorme mérito de I. Prigogine. Ela desautomatiza o quadro do mundo. Posto que os processos que transcorrem na sociedade humana, em sua maioria, podem ser caracterizados como processos irreversíveis, que têm lugar em situações de intenso desequilíbrio, precisamente eles são os que interessam especialmente ao historiador da cultura (p.147-8).
\end{abstract}

Assim, a intervenção intelectual de um cientista num objeto muda toda a dinâmica. $\mathrm{O}$ intelecto é o resultado de desenvolvimento de processos assimétricos e irreversíveis (cérebro) que interage na presença da casualidade da natureza.

A imprevisibilidade do aparecimento da aids foi um momento de crise na cultura. As mentes pensantes precisaram ir em busca de informações e pesquisas em laboratórios. Cada descoberta, vírus HIV, novos medicamentos; fez com que o sujeito (pesquisador) voltasse ao passado para corrigir a história e, assim indefinidamente.

Esse fenômeno faz com que o sujeito volte ao passado para submeter o seu conhecimento a uma "correção" na própria memória, ou relato, a partir daquele achado. A imprevisibilidade é, então, substituída na consciência do observador pela regularidade, ou seja, um esforço para voltar ao equilíbrio na estrutura inicial (LÓTMAN, 1999). 


\subsection{O LUGAR DA BIBLIOTECA NA PERSPECTIVA DOS PESQUISADORES}

A biblioteca também está se transformando? A biblioteca, integrante dos sistemas de informação, está voltada para a divulgação do saber e coloca-se como guardiã da memória da cultura. A biblioteca está passando do núcleo para a periferia na cultura acadêmica?

A biblioteca passou por várias transformações no processo histórico. Um primeiro rompimento ocorreu com a descoberta da imprensa, que separou as bibliotecas das atividades de reprodução ou edição, antes executadas pelos copistas dentro das bibliotecas. Outra transformação ocorreu no século XVII com as classificações e bibliografias, que passaram para a responsabilidade de outras instituições: os centros de documentação e que, consequentemente, originaram a disciplina Documentação (ORTEGA, 2004).

Diferenças culturais também são observadas no desenvolvimento conceitual das bibliotecas na Europa e Estados Unidos no século passado. Enquanto a Europa se recuperava da devastação da Guerra, os Estados Unidos prosperaram no desenvolvimento da área da Ciência da Informação. Na União Soviética, a Ciência da Informação recebeu o nome de Informatika e era uma disciplina responsável pelo estudo da estrutura e peculiaridades da informação científica e as leis que regem essas atividades. Para os russos, a ação dos bibliotecários era essencial, pois, possuíam um papel pedagógico e formativo. Entretanto, o conceito americano para ciência da informação predominou na contemporaneidade com um enfoque mais teórico e comercial (ORTEGA, 2004).

Os méritos da biblioteconomia, documentação, ciência da informação, ou qualquer outro nome que receba, são apontados por ORTEGA (2004): preservação documentária, prestação de serviços para acesso e uso e possibilidade do acesso e uso dos seus documentos.

Outro autor, ANGLADA (2014) aborda três etapas principais pelas quais passaram e passam as bibliotecas para se automatizarem e cria uma fórmula para medir a sustentabilidade em cada uma das etapas. A fórmula tem como base o valor do serviço e acervo que fornecem, relacionados ao uso, à percepção dos usuários e ao custo. 
A primeira etapa é a da mecanização, caracterizada por acervos impressos ou em suportes físicos (discos, fitas cassetes) e utilizando tecnologias mecânicas para sua organização. Aplicando a sua fórmula, o nível de sustentabilidade dessas bibliotecas foi alto. A segunda etapa é a da automatização, caracterizada, principalmente, pela organização dos dados dos acervos estarem em catálogos compartilhados, disponíveis para acesso em computadores. Nessa fase, a sustentabilidade das bibliotecas também foi alta. A terceira fase é a da digitalização, caracterizada pela internet e acervos digitais. A sustentabilidade na terceira fase foi baixa, principalmente, pelos altos custos e expectativas não cumpridas.

A partir desse resultado, ANGLADA (2014) apresenta alternativas para aumentar a sustentabilidade das bibliotecas, que são, resumidamente: organizar serviços de apoio às pesquisas, evitar custos e duplicações de atividades, oferecer horários de atendimento mais adequados, participar de redes sociais para comunicar serviços, investir na melhoria da percepção ou imagem da biblioteca aos usuários, entre outras.

No imaginário do senso comum, a biblioteca ainda carrega o traço da época medieval, um local silencioso, que guarda ou "esconde" toda a memória da cultura. Cabe lembrar que a biblioteca retratada no livro de Umberto Eco, "O Nome da Rosa", representa ainda a estrutura básica nas mentes de várias culturas. As universidades são ambientes que contribuem para o desenvolvimento das bibliotecas, incorporando acervos e tecnologias e expandindo seu cerne educativo. A opinião dos pesquisadores é primordial para ajustar seus serviços, adequar suas metas, corrigir suas falhas e garantir a preservação da cultura, promovendo a criação de novas linguagens.

O psicólogo e professor Marcos, de São Paulo, tem uma posição contraditória sobre a biblioteca. Ao mesmo tempo em que menciona a biblioteca como ajudando na utilização de bases de dados, informa sobre um livro que admira sobre buscas bibliográficas, escrito por professores, mas desvinculado de bibliotecas. Ele menciona o rico acervo das bibliotecas, entretanto, expõe a experiência negativa de procurar livros e não encontrá-los:

... você vira rato de biblioteca, você descobre um livro que perderam... Isso sempre acontece comigo, sempre, aí... mas cadê esse livro? 'Não, não está'

A ênfase na palavra "sempre" parece indicar certa indignação do pesquisador, que se sente sem sorte, como uma vítima da desorganização. Por outro lado, por se 
considerar um "rato de biblioteca" também se coloca como um "herói" que encontra livros perdidos pela agilidade e frequência no local. Embora ele soubesse que uma das entrevistadoras era bibliotecária, parece não ter se incomodado, ou, ao contrário, poderia estar enviando, ao que parece, uma mensagem a ser transmitida pela entrevistadora aos seus colegas bibliotecários sobre os livros não encontrados. Sua narrativa caracteriza-se como uma crítica aos bibliotecários, percebida sutilmente, e sua visão de biblioteca está voltada para a biblioteca tradicional: repositório de livros.

Outra crítica à biblioteca foi feita por Eliane, de São Paulo, sobre o horário de atendimento. Ela considera a dificuldade no acesso à informação, relatando que a indisponibilidade de algumas bibliotecas contribui para a falta de localização de informação:

É, o acesso ao texto, a disponibilidade dos livros nas bibliotecas, outra coisa também é o horário disponível das bibliotecas. Então vai, uma biblioteca aqui (...) Acho que é uma das melhores, que tem um acervo muito grande, mas não abre de sábado, eu trabalho de segunda à sexta e de sábado não tem. Eu não posso ir lá, posso usar como ex-aluna, tenho esse direito, mas o acesso às bibliotecas também não tem. As outras bibliotecas públicas, eu uso muito biblioteca pública, eu tenho carteirinha aqui dessa circulante (...), tenho carteirinha lá da $X$, porque eu morava lá. Tenho até da Infanto juvenil aqui na Praça, que é perto de casa. Porque eu gosto de livro, não gosto muito de ler no computador, eu gosto de ter o papel.

O horário de funcionamento das bibliotecas, abordado por ela, é limitado pelas administrações institucionais, dependendo de infraestrutura para manter os ambientes abertos e seguros. A possibilidade de acesso à internet facilitou as instituições, que podem manter somente os equipamentos de informática em funcionamento e atender os clientes noite e dia, ininterruptamente.

Na perspectiva dessa pesquisadora, houve uma associação da biblioteca com textos impressos, principalmente livros, que remete à biblioteca tradicional. Sabendo que a entrevistadora era bibliotecária, ela justifica-se por usar o Google, devido à indisponibilidade das bibliotecas. O Google parece ser um instrumento proibido no contexto das bibliotecas, embora a entrevistadora tenha se colocado numa posição imparcial. A pesquisadora acentua que tem cadastro em várias bibliotecas e prefere ler livros impressos, mas que está mudando a maneira de buscar a informação: 
E aí nem sempre você tem os títulos mais recentes, e aí a coisa do Google acadêmico eu acho que facilita. Eu não percebo que seja só eu não, eu vejo muita gente fazendo pesquisa pela Scholar Google.

Outra pesquisadora, a estatística Suely, do Rio de Janeiro, argumentou que usa pouco a biblioteca devido à indisponibilidade de horário. Abaixo, está transcrito o diálogo com a entrevistadora:

Suely: Então, eu acho que dez anos atrás o melhor seria procurar uma biblioteca.

Entrevistadora: $O$ que especificamente na biblioteca? Assim, solicitar ajuda de alguém?

Suely: Solicitar ajuda... é provavelmente. Solicitar ajuda e se não tivesse...

Entrevistadora: Que dados você forneceria, então, para uma bibliotecária te ajudar, se fosse dez anos atrás?

Suely: O tema, (HumHum.) né? Alguns autores, que eu sei que escrevem sobre esse tema. Acho que só.

(...)

Entrevistadora: Você usa biblioteca?

Suely: Pouco ultimamente.

Entrevistadora: Tá, mas no mestrado você usou?

Suely: Sim, no mestrado eu usei.

Entrevistadora: Você usava mais então para pegar artigo completo?

Suely: Isso e para ter acesso a livros também, né?

Entrevistadora: Ah, tá! No doutorado, você por enquanto...?

Suely: Não, ainda não utilizei.

Entrevistadora: Mas você acha que você vai precisar?

Suely: Vou, eu não utilizei até por conta de uma... Porque eu já precisei e não pude utilizar, porque a nossa biblioteca da X, né? (HumHum.) Que tem algumas, alguns livros que seriam de meu interesse, ela estava fechada para obras. Nem sei se ela ainda reabriu.

Entrevistadora: Então, principalmente para livro e eventualmente para pegar texto completo? Que não tem, que também não são todos, né? Que a instituição assina?

O diálogo indica desinteresse pelo uso da biblioteca, a entrevistadora insiste na questão e Suely justifica com a indisponibilidade da biblioteca. A pesquisadora informa que a biblioteca foi usada para acessar livros, ou seja, uma visão de biblioteca tradicional. Ao ser indagada sobre o uso da biblioteca para acessar artigos, ela 
respondeu afirmativamente, mas, pela íntegra da narrativa, não parece ser uma prioridade de uso.

A psicóloga e professora Raquel (São Paulo) faz críticas quanto ao preconceito das bibliotecas com a "grey literature", ou seja, documentos de divulgação, folhetos, artigos considerados não científicos. Ao contrário da associação feita pela psicóloga Eliane, ela diz que as bibliotecas não estão mais aceitando doações de bibliografias impressas, chamadas por ela de "coisa física". Ela reclama que sua Biblioteca não aceita certas doações por considerarem literatura informal:

Eliane: Então, é um problema. Eu acho que uma das questões é que as bibliotecas não estão aceitando coisa física, ta muito difícil. Então, outro dia eu descobri que, eu recebo o caderno Pagu, que é um journal na área de sexualidade, eu recebo. O que eu faço, diretamente: eu dôo tudo, não fica nada comigo, mesmo todas as revistas que eu recebo, porque sou colaboradora, eu entrego na biblioteca na expectativa que esteja lá, naquela biblioteca. (Claro.) Estou lá dentro da minha sala, vou lá e vejo, estou atendendo um aluno, um orientando, falo: 'Vai lá que ta lá. A biblioteca passou pra Ciências Sociais sem me consultar (Ah!). Eu fiquei puta da vida, o caderno Pagu, dez anos de Pagu, achou que o melhor lugar era lá, fiquei puta, ta certo? Não aceita livros muito facilmente e não aceita grey literature, que é justamente a literatura que faz a interseção entre, entre o saber acadêmico, então, entendeu o que eu quero dizer?

Entrevistadora: Entendi. Coloca muita coisa acadêmica e não coloca coisa pra atingir a população mais leiga.

Eliane: Isso. Então não aceita cartilha, não aceita, entendeu?

Para essa pesquisadora, a biblioteca quer se manter tradicional, sendo pouco ousada quanto à seleção de material diversificado, como vídeos e literatura cinzenta, conhecido como acervo não convencional.

A pesquisadora parece estar indignada, relatando sua insatisfação pela desconsideração da biblioteca de sua instituição, que repassou o material doado para outra. Ela considera que as publicações acadêmicas demoram muito no processo de divulgação devido à morosidade na revisão por pares e que a literatura cinzenta ("grey literature") e vídeos são divulgados mais rapidamente e atingem a comunidade que trabalha com a assistência à saúde:

...É muito lento. Então, até que alguém vai ler o seu no meio de duzentos artigos e se inspirar por aquilo. E aí nós temos o compromisso, (HumHum.) de imediatamente tá transformando isso em saber prático, 
em algo que afete a organização do serviço, ou atendimento aos portadores, a prevenção da ponta. Pra fazer isso, a gente tem que ter tido o cuidado de produzir material, (HumHum.) que não é propriamente acadêmico. E eu não vejo isso ser valorizado nas bibliotecas acadêmicas, (HumHum.) entendeu? Que acaba expulsando, ou selecionando o material e não deixando. Então, por exemplo, a videoteca é superimportante pra que aí eu vou fazer uma capacitação, fazer um curso de extensão, eu preciso de material desse tipo. (Certo.)

As bibliotecas modernas, para conter o aumento indiscriminado do acervo, adotam medidas de contenção, como descarte de publicações obsoletas, seleção mais rígida de acervo e compartilhamento de acervo com outras bibliotecas. Essa temática é estudada amplamente pela disciplina desenvolvimento de coleções na área da ciência da informação (VERGUEIRO, 1993). Dessa forma, as bibliotecas tentam resolver o problema de falta de espaço e a dificuldade em preservar grandes acervos. Essa medida agrada parte dos usuários, que dispõe de ambientes mais espaçosos e acervo mais seletivo e convencional. Ao mesmo tempo, desagrada outros, que consideram a literatura não convencional importante para o desenvolvimento de estudos.

Esse dilema está longe de ser solucionado, porém os repositórios digitais institucionais e a possibilidade de publicação na web sem o crivo de especialistas apontam para algumas alternativas para a divulgação da literatura não convencional.

A psicóloga Daniela, de São Paulo, percebe a biblioteca como um ambiente de conforto, mas limitada nos serviços que presta. Fala da possibilidade de encontrar informação importante por meio de contato com os pesquisadores:

A gente foi na biblioteca da $X$, porque eu estou trabalhando numa parceria com pesquisadores universitários (...) Então a gente foi para biblioteca da X fazer essa pesquisa. Agora em paralelo, não sei se é isso que te interessa, eu tenho feito um tipo de busca totalmente não sistemático que tem a ver com o fato de estar dentro do campo vendo coisas. Então, por exemplo, eu fui no ano passado para África do Sul na conferência de vacinas que aconteceu lá, num evento satélite deste tipo que a gente está querendo organizar. Agora teve uma mesa em particular que eu discuti pesquisa social e gênero relacionado ao campo de vacinas e um pesquisador sul-africano fez uma apresentação sobre estratégias para identificação de populações de difícil acesso, focado especificamente em pontuação HSH, e ele deu a sensação de que era como se estivesse respondendo a uma pergunta minha. Então ele foi assim: Ah tentar um tipo de metodologia e dava referência bibliográfica, 
tentar um outro tipo de metodologia e dava a referência que ele usou. Então, eu sai que nem uma maluca anotando todas as dicas dele, mandei para o meu assistente, o cara que trabalha comigo no X, falando olha as referência estão incompletas, mas eu acho que com o que tem aí dá para vocês encontrarem. E a biblioteca do X então foi e caçou, achou praticamente tudo e acho que duas referências só, muito distantes do universo da aids é que foram mais difícil de achar.

Por estar envolvida em outros ambientes "dentro do campo vendo coisas", o seu contato e interlocução com outros pesquisadores contribui para suas pesquisas, pelas sugestões que apresentam por intermédio das referências citadas. A biblioteca é acionada para a localização dos textos e sua experiência, nesse caso, foi bem sucedida.

O lado positivo da biblioteca para ela fica explicitado na narrativa seguinte, mas também são apontados os limites:

Daniela: A outra é que, por outro lado, por mais que a gente tenha acesso, às vezes, a descobrir que tal revista publicou a informação $X$ dependendo da inserção institucional, e eu acho que o X tem uma biblioteca organizada que faz parte do sistema BIREME. Então, do ponto de vista institucional, eu acho também que nunca tinha tido este conforto tão grande, que às vezes mesmo estando na USP não necessariamente seu grupo tenha uma relação privilegiada com a biblioteca. Lá é uma relação muito privilegiada, que eu mando um email falando 'olha eu achei aqui essas referências e elas me devolvem'. Eu acho engraçado até assim, porque eu tenho a sensação sempre que a biblioteca lá é menos utilizada pelos profissionais do que deveria. Então, quando eu comecei eu falei 'ah acho que eu vou fazer a festa, elas vão ficar felizes da vida', mas eu achei engraçado que, quando eu comecei, teve umas fases que eu tive um volume muito grande e dai assim 'ah não, mas a gente pode mandar até não sei quantos, mas tudo isso que o você está pedindo não pode'.

Entrevistadora: (risos) Tinha limite?

Daniela: Ninguém pede ajuda para elas, alguém que pede ainda tem que receber limite? Mas acho que é uma inserção privilegiada. Eu acho que uma coisa que ainda é um dificultador, um obstáculo, é que, dependendo da revista, ela não é de acesso livre. E eu também acho que tem um pouco essa fantasia de que eu acho que isso vai também mudar, que vai ter mecanismos mais de tornar esta informação mais livre. Vi, por exemplo, eu até ia trazer para vocês, mas eu posso depois mandar, agora nesta reunião, por exemplo, que a UNAIDS organizou um sistema desse tipo e já disponibilizando a informação, não sei se vocês chegaram a ver.

Nessa narrativa ela menciona sua percepção da biblioteca como subutilizada. Nesse contexto, considerou que sua demanda seria motivo de ser bem recebida pelas 
bibliotecárias: "elas vão ficar felizes da vida”, mas se surpreendeu com a existência de limite para o envio de artigos resultantes de busca. Fica a questão do por que a pesquisadora achou que a biblioteca era subutilizada. Na percepção do usuário de um serviço, a quantidade de pessoas denota a utilização do mesmo, se não há filas, considera-se que não há atividades a fazer. Os comentários dos outros usuários do serviço podem ter influenciado em sua opinião. Outra questão refere-se às restrições no atendimento. A pesquisadora considera que o limite era desnecessário, mas pode desconhecer as outras atividades desenvolvidas pelos funcionários. Ao comparar o atendimento de duas bibliotecas, a pesquisadora informa que são diferentes e revela a sua visão da biblioteca como prestadora de serviços, prioritariamente.

A psicóloga Luana, de São Paulo, relata o que seria um importante serviço das bibliotecas: serviço de recuperação da informação. Ela não considera que seja função da biblioteca procurar trabalhos sobre um tema para um usuário. Depois, em diálogo com a entrevistadora, expõe a dificuldade em ser atendida pela biblioteca por email, revelando uma experiência negativa. Abaixo está a transcrição do diálogo entre a psicóloga e as entrevistadoras, sendo uma delas bibliotecária e outra, psicóloga, como ela:

Luana: Então isso é uma coisa muito legal. E aí assim, uma pessoa que ta lá, de bom humor pra te atender. Então se a gente tivesse um espaço, ou uma organização, né? Ou uma, uma, um departamento na universidade, onde a gente pudesse falar assim: 'Olha, vocês sabem onde a gente pode encontrar tal informação, sobre tal coisa?' Mesmo que a gente tenha que buscar, a gente pelo menos tem o direcionamento de qual caminho procurar, (Certo.) então isso facilitou muito os acessos ao que a gente não tinha.

Entrevistadora 1 (colega psicóloga): Mas você não acha também que isso, sei lá, não sei se, vai ao encontro um pouco com o que é função da biblioteca?

Luana: É... sim. Se a gente conseguisse, é porque assim nela você não consegue ter a informação, você manda um e-mail pra biblioteca e a biblioteca não te manda isso. Se você manda um e-mail pra biblioteca, ela não vai te mandar o que, que vocês têm sobre determinado tema. Acho que a pergunta assim, se você perguntar, se você tem esse título, aí eles te respondem.

Entrevistadora 1 (colega psicóloga): Ah, então quando você já tem um trabalho... (É.) Não pra busca, não pra busca bibliográfica você está falando. Você ta falando pra encontrar um trabalho?

Luana: Por exemplo, assim: eu quero começar uma pesquisa de aids, de aids e religião, (HumHum..) Ok. Então a gente tem aqui tudo que trabalha com aids, né? Então se você entra no site, por exemplo, do PN 
você não tem nada lá, os nossos órgãos de referência não disponibilizam nem links, nem lugares pra você procurar. (Ah, tá) Alguma ferramenta que ajudasse um pouco a direcionar o caminho, então assim, procura na biblioteca da USP, que na biblioteca da USP tem, tem o NEPAIDS lá. Então vai lá e traz o NEPAIDS, porque o NEPAIDS tem. Aí, se o NEPAIDS precisa de algumas coisas, então onde o NEPAIDS procura, tem o lugar, entendeu? Então assim tem um pouco, (Entendi.) ter algum lugar que ajudasse a gente a ter alguns links de outros lugares.

Entrevistadora 2 (bibliotecária): Você acha que se você mandasse um email pra biblioteca lá da X, falando onde que você ia ter que fazer essa pesquisa, e onde que você pode procurar, você acha que eles não responderiam, desse jeito?

Luana: Não, eles não respondem. Eu já perguntei.

Entrevistadora 2 (bibliotecária): Você já perguntou?

Luana: Eu já perguntei, tá? Eu perguntei assim, genérico, assim, mas o tema você precisa ser mais específico. 'Que título você tá procurando?'.

Entrevistadora 2 (bibliotecária): Não o tema?

Luana: Não, não. Porque no tema o que você tem você consegue fazer isso virtualmente, então você consegue entrar no Dedalus e ver tudo que tem nas bibliotecas, então você já sabe.

Nesse diálogo, fica claro o imaginário da pesquisadora sobre a biblioteca, como um lugar onde se busca um trabalho pontual, ou seja, uma biblioteca tradicional. Pode ser que sua experiência esteja restrita à biblioteca de sua instituição. $O$ fato da pesquisadora não ter recebido resposta por email, indica uma falha direta no processo comunicativo. Primeiro, ela diz que não responderam e, na continuidade do diálogo, informa que responderam parcialmente. A contradição ou correção na sua colocação parece indicar incerteza ou preocupação em denunciar uma falha no serviço. Em seguida, quando indagada sobre os serviços virtuais substituírem a ida à biblioteca, argumentou sobre outros motivos para frequentá-la:

(...) Porque assim, quando você vai à biblioteca você não vai só ver os livros, você tem uma conversa com as pessoas que estão lá com o bibliotecário, com a bibliotecária, que eu acho que te traz novos elementos que o ambiente virtual não te traz, porque é você com você mesmo. Então assim, por exemplo, se essa conversa de você ir até lá, e falar: 'Olha, escuta. Eu achei que esse livro com relação a esse tema, o que mais você tem?' E ela te falar outra coisa que possa te interessar, que foi isso que aconteceu, por exemplo, no caso dos católicos, porque tem coisas que se eu achasse na internet, eu não ia buscar mais informações. Porque acho que assim, ok então é suficiente, mas tem outras coisas que você vai descobrindo, que você só descobre quando 
você encontra outras pessoas que pensam fora da caixinha onde você ta, né? Então acho que o, a questão da internet, ela tem uma limitação. Então assim, ela não, ela não se resume, e não é só porque o conhecimento, também o conhecimento ele acaba sendo, acaba sendo muito mais raso, né? Então, assim, mesmo que você tenha os livros, o resumo dos livros, você acaba lendo o resumo do livro, você tem é, os artigos que na verdade são a tradução de um trabalho, que é muito maior e que quando você vai lá você acaba tendo acesso ao trabalho muito maior, e você fala: 'Poxa vida, mas ele resumiu a parte que não era a parte mais interessante' e então você acaba tendo acesso, a conversa com as outras pessoas, então assim, essa conversa, né?

Novamente, percebe-se contradição no conteúdo da narrativa dessa pesquisadora. Ela cita a importância do diálogo com os profissionais da biblioteca para encontrar informações relevantes, quando diz sobre "pessoas fora da caixinha" e que no ambiente virtual você comunica-se consigo mesmo. Depois considera que um resumo de livro pode não ter destacado as partes mais importantes para ela. Assim, ela coloca em dúvida a eficácia dos metadados, normalmente elaborados pelos bibliotecários. $\mathrm{O}$ bibliotecário sintetiza em dados informações sobre livros e documentos numa linguagem documentária, que, do ponto de vista dessa psicóloga, perdeu informações importantes. Subentende-se, pela fala da entrevistada, alguma ironia a respeito.

Assim, nessas narrativas apresentadas, nota-se dificuldade de comunicação entre a biblioteca e os pesquisadores. $O$ pesquisador não entende o tipo de serviço que o bibliotecário oferece, além de não demandar. O bibliotecário parece não divulgar claramente os serviços prestados. Há uma assimetria na comunicação.

O médico de São Paulo, Ronaldo, enfatiza a importância da comunicação pessoal com os profissionais da biblioteca. Ele critica o atendimento da biblioteca da sua instituição, comparando-a com a de outra:

(...) eu sempre encaminhei para cá porque a assistência da Biblioteca da $X$ é péssima, só falta bater em você quando você pede para ajudar, aqui não, aqui é completamente diferente. Então, eu sempre recomendo vir nesta biblioteca, pega uma bibliotecária, pede para te ajudar, diz quais são as suas necessidades, e então tem uma ajuda, mas, às vezes, indiretamente. Quando eu fiz o meu doutorado eu fiz minha pesquisa aqui mesmo nesta biblioteca e aí eu tinha ajuda do bibliotecário.

Quando usa a expressão "só falta bater...” expõe indignação, ilustrando, com uma cena de violência, o atendimento sem qualidade armazenado na sua memória. 
Entretanto, Ronaldo tem também experiências positivas com bibliotecas. O fato da entrevista ter sido realizada no ambiente de uma biblioteca, que remete a boas experiências vividas por ele, pode ter influenciado o seu discurso e o conduzido como uma forma de gratidão pelos serviços prestados. Seja como for, a biblioteca tem um papel presente na vida acadêmica do pesquisador. Quando convidado a relatar uma cena imaginada para o futuro, o pesquisador evidencia a importância da biblioteca:

Você vai, puxa o programa de busca seletiva do material que você precisa, dá as ordens, vai fazer outra coisa enquanto ele está fazendo essa busca para você. Depois, você pega essa busca, imprime algumas coisas que você acha interessante e manda uma ordem para que ele localize as fontes disponíveis daquelas coisas que já estiverem informatizadas. Ele manda para o seu computador o arquivo informatizado, que quando ele vem informatizado ele entra automaticamente em contato com a biblioteca para providenciar uma cópia para mandar para o seu endereço, a biblioteca já recebe o seu endereço...

Ao descrever a cena de busca de informação no futuro, o pesquisador apresenta um sistema já experimentado estruturalmente. As ações descritas são intrassistêmicas: acionar um programa, dar comandos, ver o resultado, selecionar, imprimir, solicitar os artigos, receber cópias. O extrassistêmico, o "novo" no processo está mencionado pelo pronome "ele", repetido várias vezes. Literalmente "ele" substitui o "programa de busca seletiva", mas como sistema de signo, trata-se de um robô ou algo automático, que substitui o bibliotecário no sistema estruturado que permanece. A biblioteca recebe a orientação desse robô para providenciar o final do processo no sistema. O robô integra o código modelizador da linguagem, embora não tenha sido explicitado no texto. Nesse caso, o texto pode ser apreendido, transformou a linguagem. Essa reflexão se inspirou a partir do texto de MACHADO (2013a).

A biblioteca continua como um sistema de signo relevante na cultura acadêmica. Em se tratando de comunicação, ao final da entrevista, o professor expõe sua opinião a respeito do contato entre pesquisadores e bibliotecários:

Agora tem uma coisa que daí é o saudosismo, né?... mas que talvez a gente tenha que considerar essas coisas, porque é a questão das pessoas. Eu lembro, no meu doutorado, a relação pessoal com os doutorados dentro da biblioteca é uma coisa que máquina nenhuma faz, que é essa coisa de conversar com você e falar assim: 'ah sabe o que eu estou pensando, será que você não encontraria uma coisa interessante em tal fonte?' Nenhuma máquina faz isso exatamente, porque é o feeling, que você vai tendo naquela troca. Então eu acho também que as iniciativas 
no sentido de apoiar pesquisadores elas não podem se fixar só nas tecnologias digamos frias de fazer isso. Eu acho que ter pessoas capacitadas e manter algum nível de contato pessoal me parece importante, e eu vejo a diferença, por exemplo, quando alunos meus vão pesquisar lá na Faculdade X e vão pesquisar aqui, porque justamente faz a diferença. As tecnologias são as mesmas, lá e cá, mas o que faz diferença é essa coisa do profissional que gosta daquilo, que está disposto, que te recebe, te escuta, conversa, discute com você, e vai junto com você, senta lá, analisa o que está aparecendo, 'será que é isso mesmo que você quer? Será que essa palavra aqui está boa? Talvez se pegar por outra palavra não é mais isso que você quer, e ai busca lá, ah é isso mesmo e tal.' Então, o apoio humano e formação de quadros capazes de lidar bem com essas tecnologias, por um lado, e ao mesmo tempo conversar com os pesquisadores eu acho insubstituível. Não dá para ter bibliotecas totalmente individuais.

Nesse caso, o pesquisador expressa-se de modo mais emocional, repetindo palavras, usando termos como "coisa" e "feeling", revelando que não encontrou a palavra certa para representar o que quer dizer. Ele cita trechos de falas de pessoas da biblioteca, trechos entrecortados, parecendo fragmentos de cenas: "será que é isso mesmo que você quer?", “Será que essa palavra aqui está boa?”. Essa argumentação é a justificativa para informar que as bibliotecas não serão substituídas pelas "máquinas", “tecnologias”, que os seres humanos são imprescindíveis para a comunicação.

Outra narrativa expressando emoções é da professora do Rio de Janeiro, Maria Helena, que descreve a biblioteca com nostalgia, quando convidada a relatar uma cena em que buscava uma informação há 10 anos:

Então, passava a tarde na biblioteca, na biblioteca da X, nessa biblioteca daqui. E tinha uma parte lá no castelo que era maravilhoso, você ficava vendo aquela vista. É lindo, né? Mas depois começou, né? Assim que começou essa coisa... Já depois quando eu fiz meu doutorado, aí já tinha esse negócio da Bireme, aí eu já entrava lá na biblioteca, ficava ali no próprio computador. Não era assim na minha sala, era na biblioteca. (...) Aí eu ficava revendo também e pedia os artigos, né? E tinha os que tinha no $X$, que era de mortalidade infantil, aí tinha que trazer lá do X, demorava uma semana, entendeu? Então, assim, agora é muito mais veloz. Essa coisa da CAPES eu acho que foi assim maravilhosa, né?

A professora faz referência a duas janelas na biblioteca: uma janela real, abertura de um prédio, da qual observava outro edifício, referindo-se ao Castelinho da Fiocruz (prédio antigo, tombado e de importância histórica), e a janela virtual ou tela do 
computador, na qual via informações pela internet, citando Bireme e CAPES. Ao citar esses portais, provavelmente, referiu-se à possibilidade de localizar artigos e solicitar por meio de serviços de comutação bibliográfica. Ao dizer "mas depois" e "começou essa coisa" refere-se ao uso do computador, internet, mudanças. Numa interpretação livre: biblioteca-janela-tempo ou a possibilidade de admirar a paisagem em oposição ao computador-pedido de artigos-velocidade (sem tempo?). Os termos "coisa" e "negócio" permitem revelar um sentido negativo da mudança.

A socióloga Fátima, de São Paulo, fez um comentário sobre como se buscava e citava informações há 10 anos, igualmente de forma nostálgica, como um contato com grandes autores vivos, uma situação de interação familiar e proximidade com os autores:

A diferença é que boa parte daquela bibliografia eram pessoas vivas, que eram professores. Então você não ia só à biblioteca e via, você falava assim: 'A Ecléa escreveu outro dia...', entendeu a diferença?

Ela considera que a internet facilitou a comunicação e o acesso à informação, principalmente para as pessoas distantes dos centros urbanos e universidades. Destacase nessa fala a visão da edificação quando diz "descer numa biblioteca":

Eu acho que pode ter, por exemplo, esta questão da internet, facilitou o mundo, né? A vida de todo mundo, porque você tem desde clássicos, até trechos de clássicos, simples pra catar, sem ir à biblioteca, que isso, por acaso, a gente tem a sorte, porque ta em São Paulo, mas imagina um cara que ta em São Carlos, (Tá.) né? Porque na USP, às vezes, eu tinha que descer numa biblioteca diferente pra ver.

O Professor do Rio de Janeiro, Expedito, disse que usa cada vez menos a biblioteca, porque consulta os trabalhos que precisa no formato digital na internet. Abaixo, sua resposta quando consultado se usa a biblioteca:

Cada vez menos, porque nós que lidamos com a epidemiologia, aqui no departamento, e a maioria tem livro, tem assinatura, um troca com outro. Agora uso mais a biblioteca da X, que condiz mais com minha especialidade do que aqui da, da X. Mas bem menos, e tá tudo facilitando, até tese, tem um portal da USP com todas as suas teses, o portal da CAPES, tá maior...

Situação semelhante foi relatada pelos bioestatísticos Amanda e Mário, do Rio de Janeiro. Eles usam a biblioteca quando não conseguem a informação que precisam na internet. Amanda também tem a imagem de espaço físico da biblioteca, precisando "descer a escada": 
Amanda: E às vezes, como eu estou em uma biblioteca é tranquilo, é só descer a escada e tem, tem muita coisa que não tem na internet, mas tem lá disponível.

Entrevistadora: Você usa bastante a biblioteca então?

Amanda: Quando não consigo na internet, sim.

Da mesma forma, Mário relata sobre a biblioteca ser a segunda opção na busca de artigos:

Eu faço sempre aqui online, só vou à biblioteca quando não tem o artigo online e eu sei que tem o periódico em alguma das bibliotecas da Fiocruz. Ou então quando eu preciso solicitar de fora, aí eu vou lá e peço para solicitar. Mas, ir na biblioteca para fazer busca, ... eu nunca pedi nem ajuda. Já tendo o artigo que eu quero e não tem no periódico CAPES, eu uso eles só para isso, ou para xerocar o artigo, quando tem o periódico aqui e não tem online.

Além do espaço físico, ele refere-se às pessoas que trabalham na biblioteca ao dizer: "vou lá e peço" e "eu uso eles". O uso implica nos serviços prestados pela biblioteca.

Outro caso em que foi relatado pouco uso da biblioteca é o da enfermeira Cristina, de São Paulo, que prefere comprar seus livros:

Era... vai dois, oitenta, oitenta e cinco, oitenta e cinco a noventa, então eu usava, às vezes, ela me ajudava, mas eu lembro que era na biblioteca... No começo sim, aí depois eu até vinha estudar aqui, mas eu usei pouco a biblioteca, se for pensar assim. Eu, mesmo livro eu compro, não se for um livro caríssimo! (É.) Não, mas eu entro lá naquele o, agora eu entro na estante virtual, mas antes não tinha, né? Eu acabava comprando, se me interessava eu...

Sobre as novas tecnologias e o papel das bibliotecas, Cristina menciona as bibliotecas não somente como um espaço tradicional, mas inseridas nos ambientes digitais:

Entrevistadora: E você usava o CD? Você tinha que dar os termos e a bibliotecária procurar?

Cristina: Não, eu até usava, porque lá no Instituto X os computadores tinham, acho que era por ano, eu num lembro direito, sabe?

Nas entrevistas do Rio de Janeiro houve ênfase na questão referente aos serviços de alertas, porque as bibliotecas da Fiocruz oferecem esse serviço. Em algumas entrevistas, a entrevistadora bibliotecária manteve um diálogo para entender se há a 
necessidade desse serviço, bem como de outros oferecidos. A seguir, está transcrita a conversa entre a entrevistadora e a estatística Juliana:

Entrevistadora: Você sabe o que é alerta bibliográfico?

Juliana: Não

Entrevistadora: São esses avisos a respeito de novas aquisições, coleções e acervo de biblioteca. Qualquer biblioteca que você tenha um acesso mais regular, você pode se cadastrar com a bibliotecária e dizer um autor ou um tema que te interessa, ou período que te interessa, e ela ai passa isso para você por e-mail, a gente tem esse serviço aqui em todas as bibliotecas da Fiocruz. Você tinha algum conhecimento?

Juliana: Não

Entrevistadora: Você tem algum interesse nisso?

Juliana: Sim

Entrevistadora: Tem muita gente que acha que facilita e tem muita gente que acha que atrapalha, porque geraria uma quantidade maior de informação na caixa postal. E tem gente que não, eu posso usar isso para filtrar melhor aquilo que me interessa. Qual seria a sua posição, você consegue imaginar?

Juliana: Assim, se você delimitar bem qual o seu interesse, eu acho que ajuda você a acompanhar as publicações.

Entrevistadora: Se você não recebesse de vários assuntos, se fosse direcionado para o interesse do que você trabalha?

Juliana: Isso

Entrevistadora: Quando você fez a iniciação científica, mestrado e doutorado, você já sabia fazer essa busca. Quem te ensinou, você fez. algum curso, como foi esse processo?

Juliana: Não, eu aprendi com o orientador durante a iniciação, antes eu nem conhecia esses sistemas.

Entrevistadora: Então foi durante essa iniciação aí e ele já te ensinou direto no PubMed?

Juliana: Isso

Entrevistadora: Você frequenta biblioteca, ou frequentou?

Juliana: Sim, frequento.

Entrevistadora: Qual é a sua necessidade?

Juliana: É mais para livros, geralmente artigos a gente vai mais para internet.

Entrevistadora: Você já chegou a precisar de Comut?

Juliana: Não.

Entrevistadora: Tudo que você precisa você consegue texto completo na web? 
Juliana: Na verdade, eu só recorri ao Comut acho que uma vez, eu achei que demorou demais, o tempo, então... tempo para o artigo chegar.

Juliana responde sucintamente, usa palavras curtas: "sim", "não" e "isso", deixando a impressão de desinteresse pelos serviços de bibliotecas. Aprendeu a usar bases de dados por intermédio do seu orientador. A biblioteca aparece como segunda opção, estando relacionada à ideia da biblioteca tradicional.

O mesmo ocorreu com outra entrevistada, estatística, do Rio de Janeiro, Sofia, que disse desconhecer o serviço de alerta:

Entrevistadora: E você recebe, assim, algum alerta bibliográfico ou participa de lista de discussões?

Sofia: Não.

Entrevistadora: Você não recebe nada disso? Você sabe que existe em bibliotecas, esse tipo de coisa?

Sofia: Não.

Entrevistadora: E algumas bases também... De alguma forma você entra na base, cadastra um perfil de seu interesse em pesquisas e, de tempos em tempos, a cada três meses, você seleciona, a base vai te mandando as referências que foram publicadas naquele período. É uma forma de você se atualizar e não receber duas vezes a mesma coisa. De agosto a outubro e depois de outubro a dezembro você recebe as referências.

Sofia: Eu acho que isso não está no escopo da pesquisa, eu acho que isso é um problema que a gente tem nas disciplinas daqui, essas coisas não são ensinadas para a gente.

Entrevistadora: Não é muito divulgado?

Sofia: Não, a gente teve uma disciplina que ensinava acessar as bases, mas não só na pós-graduação, mas principalmente na própria graduação mesmo. Eu fui ver o que era um artigo quando eu entrei no mestrado.(...) E eu não aprendi isso, eu acho que isso precisa ser mais divulgado entre os alunos mesmo.

Entrevistadora: Você imagina que isso, por exemplo, que ter este tipo de recurso, de receber atualização, esses alertas de referência bibliográfica, você acha que isso facilitaria?

Sofia: Bastante, eu acho que sim, porque, às vezes, assim, eu não tenho o costume de fazer isso, mas se eu for pensar, se eu recebo esse alerta, eu não vou me policiar para todo mês, ou a cada dois meses, ficar lá: 'o que tem de novo?' Então, se eu recebo, eu acho que isso já vai criando outro hábito.

Nesse caso, a pesquisadora Sofia mencionaou maior interesse nas explicações da entrevistadora-bibliotecária, pois interagiu com ela, diferentemente da outra, Juliana. 
A avaliação da qualidade de serviços prestados pelas bibliotecas é bastante divulgada na literatura científica e adota modelos norte-americanos, como o Servqual/Libqual (FREITAS e col., 2008). Geralmente, as medidas a serem tomadas implicam em mudança de atitude na cultura, processos complexos, que não ocorrem somente com a promoção de cursos de capacitação profissional, muito comuns nesses casos.

O Prof. Valter de São Paulo faz uma reflexão sobre a biblioteca tradicional e os portais virtuais:

Eu acho que portais como esses que eu tava dando exemplo, dos experts, eu acho que setor como a biblioteca, é claro que não é essa a vocação inicial da biblioteca, mas é meio inerentes ela, do mesmo jeito que ela já é um portal físico, ela faz uma seleção quando ela já assina a revista, ela faz uma seleção da revista que é relevante, então quando você vai à biblioteca tem uma seleção prévia de livros de titulos, periodicos e tal que são relevantes pra área. Eu acho que a tendência futura são as bibliotecas replicarem isso na área virtual, eu acho que estes portais do tipo especialistas, dos pesquisadores,...

O pesquisador usa repetidamente o pronome "ela", indicando a biblioteca, que seleciona acervo relevante para uso de especialistas como os portais virtuais. Mais à frente, na entrevista, quando a entrevistadora perguntou se era verdade que ele ainda usa bastante a biblioteca, ele respondeu afirmativamente:

Uso, principalmente na parte de livros, agora com as bases virtuais etc, eu uso menos fisicamente na parte de periódicos.

Ao indicar que usa menos a biblioteca para consultar o acervo de periódicos, ele parece entender que o acervo digital é de responsabilidade da instituição biblioteca.

A professora Diana, Rio de Janeiro, relatou usar mais a biblioteca no período em que morou no exterior (EUA), onde participou de disciplina de revisão bibliográfica oferecida pela biblioteca e foi bem acolhida. Informou que, atualmente, usa indiretamente por intermédio dos alunos e estagiários:

Diana: (...)Não prescindi nem da biblioteca, não prescindi de conversar com pessoas sobre esse assunto (...)

Entrevistadora: Você faz uso da biblioteca?

Diana: Eu peço pras pessoas irem pra mim. [Risos]

Em algumas entrevistas foi abordada a questão da biblioteca como educadora, oferecendo treinamentos para os usuários sobre como usar as bases de dados. Vários 
pesquisadores mencionaram essa questão, sobretudo os atuantes em São Paulo. Alguns exemplos serão apresentados a seguir.

A psicóloga Márcia, de São Paulo, disse que participou de cursos em bibliotecas, recebendo muita ajuda, por isso, deixou um agradecimento aos bibliotecários que a ajudaram:

Acho que a Carminha (entrevistadora) foi uma das professoras. [Risos]

Eu vim fazer um curso, aqueles cursos que a biblioteca oferece, né? Que são bastante práticos porque é...você consegue encaixar na agenda porque tem várias possibilidades de horário e eles estão sempre sendo reproduzidos. Eles são curtos e bem objetivos, então, eu fiz, eu fiz sim um curso, esse é um trabalho, acho que, bem interessante que a biblioteca oferece e quando eu precisava de alguma coisa assim que eu não soubesse, enfim, que eu sozinha não conseguia, as próprias bibliotecárias me ajudavam. (...)

Lá no Instituto de X eu faço até um agradecimento especial para os bibliotecários de lá porque, é, me ajudou bastante...

O professor Rogério, de São Paulo, também relatou a participação nesses treinamentos:

Eu fui treinado por esta Faculdade quinze anos atrás, eu acho (...) eu aprendi o vocabulário controlado, o que é o vocabulário controlado

O médico e professor Luís, de São Paulo, descreve a biblioteca como grande colaboradora na educação dos alunos. Ele relata detalhadamente sobre uma disciplina oferecida pela biblioteca da instituição em que atua, que é ministrada por bibliotecárias:

Agora fora isso, digo assim, a gente tem essa disciplina, nós temos duas bibliotecárias lá da nossa faculdade, que nós estimulamos no passado, independentemente da Casa da Aids, no programa de pós graduação em doenças infecciosas, para que montassem uma disciplina de pesquisa bibliográfica em bases de dados informatizados. E elas elaboraram essa pesquisa, essa disciplina, faz muitos anos, e essa é a única. É assim: as nossas disciplinas são oferecidas a cada dois anos, são bienais, essa é a única disciplina que é oferecida todo ano porque ela tem uma demanda incrível, não só com os alunos do nosso programa, mas com os alunos de muitos programas da faculdade que sabem tradicionalmente que essa disciplina existe. E aí os nossos profissionais, mesmo que não estejam na pós-graduação, por eles estarem envolvidos com pesquisa a gente sempre estimulou que eles participassem dessa disciplina. Ela exige uma infraestrutura de laboratório de informática, que nós não temos aqui, então por isso ela é ministrada lá na faculdade, numa sala que a gente tem de vinte a vinte e cinco máquinas em que cada aluno pode ficar, fazendo hands on, mexendo na sua máquina. Ela é uma disciplina essencialmente prática, existe uma apostila com uma síntese da teoria 
basicamente, mas ela é essencialmente prática e operacional pra que o indivíduo manipule as bases de dados e conheça todo o arsenal que o acervo da USP permite buscar ou internamente ou externamente nas bases de dados informatizados.

Esses pesquisadores qualificam os treinamentos, ou capacitação, como essencialmente práticos, inclusive com o uso de computadores pelos alunos para exercitarem nas aulas. Essa atividade educativa é um assunto bastante estudado pela Ciência da Informação e conhecido como competência em informação, ou, mais popularmente, pelo seu nome em inglês information literacy (ALVAREZ e col., 2013).

$\mathrm{Na}$ área acadêmica, a função educativa é inerente à categoria profissional dos docentes, responsáveis pela formação dos alunos das universidades. No entanto, alguns bibliotecários assumiram essa atividade no que concerne ao acesso e uso da informação bibliográfica. A atividade, iniciada nas bibliotecas informalmente e pouco estruturada, foi tornando-se mais regulamentada em algumas instituições a ponto de tornarem-se disciplinas curriculares (COBUS, 2008).

A cultura dos bibliotecários foi se apropriando da atividade de ensino, conhecendo suas linguagens e sistemas codificados e criando novos modelos, adaptando e incorporando na sua cultura o que antes estava além da fronteira da sua competência. $\mathrm{Na}$ outra cultura, a dos professores, também ocorreu transformação da linguagem quando em contato com a fronteira da cultura dos bibliotecários, dos sistemas e linguagens de busca da informação. Esse é um exemplo característico dos movimentos semióticos e sua importância na comunicação.

Pensando nessas culturas como textos, ou seja, completamente organizados, que se decompõem em hierarquias de outros textos (LÓTMAN, 1990), pode-se identificar que características das atividades docentes foram adotadas pelos bibliotecários: lista de presença, sala de aula, horários dos treinamentos, organização de material didático, como expressado por Luís, quando afirma que "existe uma apostila com uma síntese da teoria basicamente". Entretanto, algumas características da cultura dos bibliotecários se mantêm, como a praticidade. Faz parte dos sistemas da cultura do bibliotecário buscar a objetividade e a praticidade, uma vez que essa profissão tem como função nuclear mediar a informação e o usuário. Essa constatação vai ao encontro do pensamento de LE COADIC (1996) sobre as pesquisas da área da ciência da informação serem mais voltadas para a prática e menos para a teoria na contemporaneidade. 
Dessa forma, a cultura se transforma, os bibliotecários desenvolvem outras habilidades, que se aproximam mais dos interesses investigativos de seus usuários. $\mathrm{O}$ mesmo ocorre com os docentes, que entendem a importância de conhecer os sistemas de informação para melhor ensinar, aprender e pesquisar. Uma cultura, em contato com outra, desempenha um mecanismo de arranque, que põe em marcha processos geradores de sentido. Assim, a memória do homem, em contato com o texto, conduz a mudanças criadoras na cadeia informacional (LÓTMAN, 1998).

Para uma cultura existir é preciso construir regras, limitar as fronteiras, ter uma identidade. Ao mesmo tempo, por inscrever-se em um sistema complexo, precisa estar aberta ao diálogo, incorporando modificações, e isso é possível por meio dos textos e códigos criados. Os textos com maior longevidade, que sobrevivem ao tempo, são os mais válidos, bem como os códigos mais válidos na cultura são os que contém elementos estruturais mais constantes e dinâmicos internamente (LÓTMAN e USPENSKII, 1971).

Há culturas orientadas pelo conteúdo, com o predomínio do sistema de regras e mais fechadas em si mesmas, e outras orientadas pela expressão de textos. Assim, identifica-se que o bibliotecário faz parte da cultura com forte orientação para os sistemas de regras, desde sua formação até às práticas profissionais: regras para catalogar, classificar, indexar a informação. Já os professores e pesquisadores fazem parte da cultura mais voltada para a produção de textos: trabalhos de pesquisa, experiências precisam ser relatadas para os pares. Ao mesmo tempo, essas culturas fazem parte de uma cultura maior, ou seja, a cultura acadêmica, ou, ainda, outras culturas como a brasileira, a ocidental, num entrelaçamento complexo.

Mesmo dentro da cultura dos pesquisadores, identificamos divisões culturais, como a dos acadêmicos e a dos profissionais da área da assistência. Os primeiros são produtores de texto e os da assistência seguem protocolos de atendimento aos pacientes, ou seja, predomina o sistema de regras. Quanto à formação, observam-se diferenças entre a área biomédica e a área voltada às humanidades. De qualquer modo, a cultura vive num mecanismo dinâmico, exigindo constante autorrenovação e, ao mesmo tempo, autoconservação (LÓTMAN e USPENSKII, 1971).

Nessa intensa relação entre as culturas, a luta pela sobrevivência se sobrepõe. A chave talvez esteja nas fronteiras das culturas, no que surge na não cultura. Os pesquisadores, na fronteira da cultura, fizeram retratos da biblioteca, alguns com 
representação positiva e outros, negativa: espaço físico, bibliotecários acomodados, bibliotecários formadores, prestação de serviço, acervo impresso, busca por material não encontrado, formatação, falta de entendimento, contato pessoal criador, entre outros. Surge daí o desafio: o de como a mesma se inova e melhor se revela frente ao usuário, em uma rica e proveitosa interlocução.

Em se tratando de ciência e seus textos, a biblioteca posiciona-se como mediadora entre os sujeitos da cultura acadêmica e científica ou promotora do diálogo entre os cientistas. As narrativas apontaram para uma tendência dos pesquisadores buscarem informações bibliográficas de autores conhecidos ou citados por seus pares, ou, ainda, aqueles que aparecem mais facilmente no Google.

Desse procedimento decorre uma contradição, pois os pesquisadores precisam buscar informações novas para definir melhor a sua cultura e seu objeto, notadamente os fenômenos complexos. E esse fechamento num núcleo faz a cultura diminuir seu dinamismo. A biblioteca, nesse sentido, tem um papel, que consideramos fundamental, de abrir esse processo e colocar os pesquisadores em contato com outros textos de modo a tirá-los do círculo vicioso, ou seja, de um sistema fechado de circulação de ideias, que dificulta a descoberta do novo, a complexidade da realidade, enfim.

A biblioteca pode contribuir para esse diálogo entre os textos da cultura, oferecendo uma gama maior de fontes de informação, com motores de busca mais sofisticados e mais qualidade na prestação de serviços, que avançam em processos graduais ou explosivos..

Na teoria de Lótman, para uma cultura se definir como tal é preciso dialogar com outras e olhar sobre si mesma numa autorreflexão (AMÉRICO, 2012). Assim, as bibliotecas podem refletir sobre o seu papel, enquanto sistema de signos no interior da cultura científica, e sustentar a sua sobrevivência, buscando sempre atualizar-se e inovar nas relações com seus usuários, notadamente pesquisadores. 


\section{SOBRE A COMUNICAÇÃO E DESAFIOS CONTEMPORÂNEOS}

A comunicação na ciência acompanha as transformações sociais. Os desafios são complexos e resumem-se nas tentativas de solucionar a redundância da informação, transformar a quantidade de informação em qualidade, preservar a memória da cultura e promover a sobrevivência da cultura, renovada, atualizada. Essas possibilidades se entrelaçam, aumentando os dilemas na cultura e instigando a novas descobertas e novos avanços.

Reduzir a redundância é um desafio, porque o grande volume de informação promove entraves para a fluidez na ciência. A informação fica descentralizada, pode se perder, não adquirindo significado. Para reduzir a redundância é preciso conhecer o que está sendo produzido para que os mesmos procedimentos não se repitam, o que é muito difícil diante da grande quantidade de informações que se apresenta. Dessa forma, é possível apenas tentar controlar as redundâncias. Em se tratando da pesquisa científica, a cobrança dos órgãos avaliadores pela quantidade é intensa e contribui para o aumento da redundância da informação, que se traduz em produzir sempre mais do mesmo, sem inovação.

A redundância da informação é característica, segundo LÓTMAN (1996), dos momentos históricos revolucionários. Transpondo tal pensamento para a atualidade, a revolução técnica e científica também pode estar contribuindo para a redundância da informação na contemporaneidade. Isso ocorre porque a sociedade utiliza novos recursos para os mesmos velhos fins, ampliando as possibilidades quantitativas. LÓTMAN exemplifica com a descoberta da escrita: a memória oral era mais seletiva, só disseminava o que era forte na cultura. Nas palavras de LÓTMAN: "a memória oral tinha um volume limitado e estabelecia rigorosamente o que era necessário conservar" (p.217). Com a possibilidade de conservar maior quantidade de informações pela escrita, ampliaram-se os estoques de informações desnecessárias e repetitivas. A escrita promoveu a possibilidade de conservação individual, que na linguagem oral era coletiva, contribuindo para o aumento da informação. Com a invenção da imprensa a situação se ampliou. Na atualidade, com a informática e as possibilidades de armazenamento de informações, a quantidade tem se mostrado desmedida. 
Entretanto, a cada grande mudança, ou revolução, ocorre a resistência. O medo do novo impele para retornar aos padrões anteriores, à tradição. Foi o que ocorreu no Renascimento, como exemplifica LÓTMAN (1996): ao mesmo tempo em que a ciência prosperou, aumentado a "previsibilidade dos acontecimentos", a sociedade da vida comum se mostrou "completamente imprevisível" (p.233). A sociedade temia a ciência, considerando feitiçaria. A atmosfera de medo propagou-se intensamente na Europa nessa época, impulsionando inclusive o desenvolvimento de outras ciências para entender tais fenômenos, como a psicologia.

Com a evolução da informática ocorreu situação similar. Observou-se certo temor na sociedade com o mito do homem ser dominado pela máquina. Na contemporaneidade, por exemplo, questionam-se os malefícios que os equipamentos eletrônicos trazem à saúde das pessoas, sejam físicos ou psicológicos. Faz parte de um processo natural de assimilação do novo, um esforço para voltar à regularidade. Tomando emprestadas palavras de LÓTMAN, 1999: "o desenvolvimento que segue parece fazer voltar para trás na consciência, ao ponto de partida da explosão" (p.30).

Igualmente, a ciência está aberta para a imprevisibilidade no mundo contemporâneo. Faz parte da natureza dessa cultura estimular confrontos, discussões, competições, principalmente ao se relatar experiências em artigos científicos (encenação de atos que acontecem em laboratórios ou estudos de campo). Nessas batalhas, vence quem tiver maior poder persuasivo (MACHADO, 2011). A imprevisibilidade pode ocorrer em qualquer contexto, seja no da descoberta ou da justificação, mas ambos não devem ser considerados, nos processos de inovação em ciência, de maneira dicotômica, conforme sinalizam ALVARENGA e col. (2015). Até mesmo na especificidade da busca bibliográfica, no caso desta pesquisa, os pesquisadores abordaram exemplos de imprevisibilidade nas entrevistas.

Tome-se o exemplo da aids para considerar a imprevisibilidade. Por que essa doença resultou e resulta em tantos trabalhos científicos e representações artísticas (cinema, artes plásticas)? Por que esse tema é tão instigante? A resposta é simples. Essa doença surgiu da miséria humana, atingiu homossexuais de todas as classes sociais e também heterossexuais, infectou mulheres em sociedades machistas, propagou-se entre usuários de drogas, foi desprezada por autoridades governamentais, foi considerada profética pelas religiões, mata milhões de pessoas, inovando os estudos em saúde e outras áreas, não somente do ponto de vista teórico, mas igualmente metodológico e 
prático. Essa imprevisibilidade e a luta pela sobrevivência são motivações para pesquisadores e artistas. Por envolver uma gama tão ampla e complexa de assuntos e disciplinas, estimula a criação de novos textos na cultura.

Focando nos grupos de pesquisa estudados (NEPAIDS E LIS), observam-se temas de pesquisa inovadores, criando novos conceitos e emprestando termos de outras áreas do conhecimento num rompimento das fronteiras disciplinares:

- Nova metodologia RDS (Respondent Driven Sampling) - interface com a área de estatística,

- Efeitos dos tratamentos antiretrovirais na distribuição da gordura corporal - interface com a nutrição,

- Terminologia nova para descrever grupos minoritários na tentativa de ser menos preconceituoso: "usuários de drogas", "homens que fazem sexo com homens", "profissionais do sexo", “órfãos negros”.

- Terminologia importada ou adaptada: "vulnerabilidade" e "branquitude".

Essa diversidade e entrelaçamento de conceitos são exemplos de criatividade. Assim, é possível relacionar a imprevisibilidade com a redução da redundância de informação e é isso que é buscado pela ciência. As culturas se encarregam de selecionar a informação que será mantida e, as consideradas de pouca expressão, previsíveis, ficarão nas fronteiras até que as mentes pensantes tenham competência semiótica para recodificá-las.

Um segundo desafio é transformar a quantidade de informação em qualidade. Para ponderar sobre a qualidade buscamos inspiração no passado e no presente. Uma ideia clássica a respeito foi encontrada na obra de Friederich Engels (1820-1895). Embora ele seja mais conhecido pelas obras elaboradas em conjunto com Marx (O Manifesto Comunista, O Capital), seu estudo em dialética da natureza é reconhecido, apesar das algumas informações já terem sido consideradas superadas pelos novos achados na ciência.

ENGELS (1979) fez críticas à ideia da invariabilidade absoluta da Natureza e à falta de visão de conjunto de alguns cientistas. Ele constatou a existência da casualidade em todas as instâncias, incluindo a ciência, e apresentou as três leis da dialética da natureza com base nas concepções de Hegel. São elas: a lei da transformação da 
quantidade em qualidade e vice-versa, a lei da interpenetração dos contrários e a lei da negação da negação. Nós deteremos somente à primeira delas, que expressa que "as mudanças qualitativas só se podem realizar por acréscimos ou subtração quantitativa da matéria ou de movimento" (p.35).

ENGELS apresentou uma série de situações que sustentam a existência dessa lei, sobretudo na área de química. O exemplo clássico é o do aquecimento crescente da água, transformando esse elemento em outro, o vapor. ENGELS acrescentou que essa lei, embora desprezada por muitos pensadores da época, aplica-se também na biologia e na história da sociedade humana.

Transpondo para o tempo presente, há que se citar o exemplo do uso do chamado big data na sociedade em rede. O big data, como mencionado na introdução desta tese, refere-se ao enorme montante de dados armazenados nos sistemas digitais. Esses dados são inseridos nos sistemas pelas pessoas que usam internet, procurando informação ou preenchendo formulários de cadastros, e podem ser estruturados por pesquisadores e utilizados para tomada de decisão.

A área da saúde tem utilizado o big data para monitorar doenças e estudar formas de prevenção. A epidemiologista Laura Rodrigues, em conferência recente, apresentou exemplos de usos do big data para a produção de conhecimento em epidemiologia (BATALHA, 2014). A ciência da informação pode usar o big data para estudar a terminologia usada pelos usuários e assim atualizar as ferramentas de busca.

Compondo a lei da dialética com o uso prático do big data, supõe-se que a atividade primordial dos pesquisadores seja caracteristicamente a transformação da quantidade em qualidade. A partir de quantidades de dados, espera-se a criação de algo novo, que modifique e melhore a vida do ser humano. Pode-se dizer que se trata de uma tradução de números para ações. Traduzir implica esforço das mentes pensantes em transformar os bits, sinais gráficos, dados e números em circuitos, programas e processos capazes de criar linguagens (MACHADO, 2011).

Segundo o grande humanista Georges Gusdorf é importante buscar ultrapassar as finalidades da ciência instrumental como um fim em si mesma, característica do paradigma hegemônico da ciência moderna, para uma nova ciência contemporânea, que tenha no homem o seu ponto de partida e o seu ponto de chegada. $\mathrm{O}$ pensamento desse autor é enfatizado e reiterado por autores como ALVARENGA e col. (2011 e 2015), 
notadamente em suas reflexões sobre os limites do pensamento disciplinar positivista da ciência moderna e a relevância de a eles se articularem novas formas de pensamento, tais como o interdisciplinar e o transdisciplinar.

Criar é próprio dos pesquisadores e artistas e o desenvolvimento das linguagens na informática ampliam as possibilidades de se intensificar. Essas ferramentas tecnológicas promovem mudanças nas formas de criação porque estão nas fronteiras da técnica comunicativa. O mesmo aumento criativo, ocorrido na invenção da escrita alfabética, da imprensa, dos aparelhos de imagem (TV), acontece com a sociedade em rede. São marcos de grandes oportunidades técnicas e científicas e cada um desses períodos está assinalado não somente por mudanças na técnica comunicativa, mas também por mudança radical no status da linguagem e seu lugar na sociedade.

Em termos de linguagem verbal, LÓTMAN (1996) exemplifica as mudanças ocorridas no Renascimento após a Idade Média. Na Idade Média, as palavras significavam objetos e fatos da vida cotidiana, com interpretação singular, sem ambiguidades. A partir do Renascimento, a linguagem adquire, segundo esse autor, certa "malícia" e as palavras recebem significados diversos, "dependendo das intenções" (p.234). Sendo assim, estudar a linguagem na contemporaneidade é importante, pois poderá contribuir para o entendimento da semiose, revelando sentido para as transformações socioculturais.

A cultura acadêmica promove a multiplicação de linguagens e tem se preocupado com a metalinguagem ou a "consciência da consciência". Essa preocupação tem se apresentado, na contemporaneidade, nos estudos com ambientes virtuais e trabalhos na área de análise do discurso (IÑIGUEZ, 2005). O pesquisador, diante do crescente número de artigos científicos, pesquisas em laboratórios e contatos com seus pares, desenvolve processos e sistemas com a finalidade de transformar essa quantidade em qualidade, sobretudo para o coletivo humano, fundamental no caso da saúde pública.

O terceiro grande desafio é a preservação da memória da cultura. Como visto neste trabalho, os textos têm como uma das funções preservar a memória da cultura e são produtos da própria cultura. Na cultura oral, a preservação ocorreu por meio dos mitos, costumes, lendas, que passavam de geração a geração, além dos registros arqueológicos. Na cultura escrita, a preservação se dá, predominantemente, nos documentos escritos, impressos, nas leis. E como se dará no futuro, com a cultura 
digital? Essa preocupação futurológica já denota a importância da preservação na cultura, é a preocupação com a sobrevivência que se sobrepõe.

No mundo digital, não é possível prever a sobrevivência da técnica, pois os sistemas são continuamente mutáveis, sejam nas versões de programas de leitura digital, na obsolescência de equipamentos ou no fugaz aparecimento e desaparecimento de redes sociais, portais e repositórios.

A biblioteca, pela sua tradição na preservação da informação e dos textos da cultura, encontra-se num grande dilema: como preservar seus acervos impressos e digitais na incontrolável explosão semiótica em que se encontra? $\mathrm{O}$ acervo impresso se deteriora com o tempo e será sempre incompleto, porque muitas publicações são exclusivamente digitais. $\mathrm{O}$ acervo digital torna-se obsoleto rapidamente, bem como os mecanismos de leitura, e o acervo também será sempre incompleto, porque não há ainda controle sobre a publicação digital e a sua sustentação. Assim, as bibliotecas procuram controlar e preservar o acervo institucional, impresso ou eletrônico, às quais estão vinculadas (LYNCH e LIPPINCOTT, 2005).

Diante desse dilema, as bibliotecas buscam alternativas, formando convênios, compatibilizando recursos, unindo esforços em associações e sistemas, tentando garantir a interoperabilidade e tantas outras medidas criativas.

Toda essa movimentação visa a garantir a sustentabilidade e sobrevivência da cultura. A estrutura semiótica permanece, "a informação sempre foi instável” seja em qualquer época, como escreveu DARNTON (2010, p.41), e a responsabilidade de preservação da memória da cultura se mantém. Mesmo o ambiente físico das bibliotecas continua a ser prioridade e se modeliza. Se, no século passado, as bibliotecas eram ambientes silenciosos, templos do saber e ficavam no centro dos campi universitários, hoje, têm seus layouts reconfigurados para atrair seu público, com poltronas confortáveis, instalação de cafés, ambientes que convidam a conversar em grupo ou a usar tablets e celulares etc. (DARNTON, 2010).

Outra característica da biblioteca da Idade Média tem retomado seu espaço, ou até mesmo se mantido, na contemporaneidade: seu papel de editora acadêmica. Em Harvard, a editora da universidade e a biblioteca estão publicando monografias de acesso livre, disponíveis gratuitamente (DARNTON, 2010). As universidades brasileiras igualmente têm a tradição de contribuir nas publicações institucionais, 
principalmente revistas, acompanhando as mudanças e publicando no formato digital. Esse é um modelo que se renova na cultura das bibliotecas atuais.

Lembrando que para se pensar no presente é necessário um diálogo com o passado e que a biblioteca é responsável pela preservação na cultura e comunicação do saber, chegamos ao outro desafio: o da sobrevivência.

A sobrevivência da cultura se dá por intermédio dos sistemas modelizantes e códigos compartilhados pelos grupos sociais ou, em outras palavras, ocorre na semiosfera. LÓTMAN (1996) usa um museu como metáfora para exemplificar a semiosfera: peças de diferentes épocas, explicações em vários idiomas (conhecidos e desconhecidos), normas de utilização, instruções para decifrar as obras, guias de várias esferas de organização sígnica e "visitantes com seus próprios mundos semióticos" (p.30). Transpondo essa metáfora para a biblioteca, entende-se que sua existência extrapola o espaço físico: textos de variadas épocas, idiomas sortidos, normas de utilização, sistemas de busca, conexão a outros textos do mundo digital, sistemas de classificação, mentes pensantes com seus mundos semióticos. Assim, seja como tradicional ou virtual, a biblioteca tende a sobreviver na cultura, sua estrutura mantémse para preservar a si própria.

O grande desafio da sobrevivência das culturas e da própria vida depende da comunicação, haja vista estudos em biodiversidade. A comunicação nas bibliotecas se dá, principalmente, entre as equipes profissionais e seus usuários e a tradução das linguagens entre esses grupos é condição para a dialógica na cultura acadêmica e científica. Um facilitador dessa tradução de linguagens na biblioteca é a promoção de programas educativos, visando à competência em informação, notadamente dos pesquisadores.

Os cursos e treinamentos relatados nas entrevistas, oferecidos pelas bibliotecas, contribuíram, ao que parece, para competência em informação dos pesquisadores. As narrativas apontaram para a aproximação das bibliotecas nas suas carreiras profissionais, alguns mais intensamente e, outros, mais superficialmente. Nessa perspectiva, podemos observar que a literatura especializada da área da ciência da informação tem apresentado experiências de entrosamento das bibliotecas no ensino tendo em vista capacitar notadamente os estudantes no acesso e uso da informação (MCCLUSKEY, 2010; SAUNDERS, 2012). 
A comunicação, entendida como semiose, é a possibilidade de desenvolver uma competência semiótica "criadora de linguagem", o que permite "o desenvolvimento de uma outra relação entre natureza e cultura". O homem culturaliza a natureza na ciência, buscando entender a "obscura linguagem da vida" e, assim, relaciona-se com o seu meio ambiente (MACHADO, 2003a, p.148). É na semiosfera que a natureza e a cultura se relacionam e se complementam.

Na área da Saúde Pública/Saúde Coletiva, essa relação da natureza e cultura fica mais evidente, dada a natureza complexa do objeto. A diversidade de linguagens é muito ampla e as trocas, os filtros e as traduções nas fronteiras intensificam as semioses na cultura. Assim, a saúde, enquanto processo biológico e social, é um sistema de grande complexidade, do ponto de vista de sua descrição, por se distinguir pelo dinamismo, fluidez e contrariedade de organização interna (MACHADO, 2013b). Desse modo, essa cultura ilustra a heterogeneidade de linguagens e seu alto poder criativo ao ser considerada como um sistema complexo, aberto, que contém em si os germes e a dinâmica da inovação em sua práxis. 


\section{CONSIDERAÇÕES FINAIS}

A diversidade de opiniões do pesquisador, sobre a ação de buscar informação científica na contemporaneidade, sustenta a dinâmica e a complexidade dos sistemas de signos envolvidos. As divergências e convergências, traduzidas nas narrativas dos pesquisadores em HIV/aids, explicitam as diferentes linguagens, ou maneiras de ver o mundo, presentes na semiosfera. Essas linguagens transformam-se a cada momento e são distintas pela variedade de formação acadêmica, atuação profissional e vivências dos pesquisadores, revelando a complexidade na cultura.

No plano da semiosfera, alguns sistemas de signos são vistos como centrais na cultura dos pesquisadores, com destaque para o Google e a base de dados PubMed/MEDLINE. O Google ganha relevância por oferecer um sistema simples e prático, evitando o desperdício de tempo. No entanto, mostra-se um sistema controlado por algoritmos, tendendo ao empobrecimento de resultados e ao domínio comercial. A base de dados PubMed/MEDLINE evidencia sua presença nos códigos da cultura da área da saúde, embora esteja dividindo espaço com o prevalecente Google.

Quanto às bibliotecas, um sistema de signo central na cultura e pouco conhecido pelo pesquisador é o tesauro $\mathrm{MeSH}$, ferramenta pouco visível ao usuário por ser complexa em sua utilização. A biblioteca aparece como um sistema de signo presente na busca de informações pelos pesquisadores, mas perde sua centralidade quando projetada para o futuro. Ela é representada com características diversificadas como: estoque de material impresso, espaço físico para leitura, prestadora de serviços, oportunidade de encontrar mentes inspiradoras e promotoras de competência em informação.

As novas tecnologias são descritas pelas suas facilidades e dificuldades, dependendo do contexto de utilização. A internet aumentou as possibilidades de comunicação, mas as tecnologias não podem ser supervalorizadas em si mesmas, sem uma reflexão. A administração do tempo e a seleção de informações relevantes para o contexto da pesquisa posicionam os sistemas de informação e bibliotecas como importantes mediadores na comunicação, ou tradutores de linguagens. Entretanto, seus papéis ainda não estão claros para os pesquisadores, que parecem desconhecer serviços e objetivos de cada um e, sobretudo, o alcance dos mesmos como tecnologia de pesquisa para a inovação na produção do conhecimento. A irregularidade na semiosfera transparece nos movimentos do centro e periferia e assimetrias observadas. 
Nesse contexto, os sistemas de busca de informação são utilizados pelo pesquisador como ferramentas de trabalho, sendo uma linguagem conhecida, embora em constante transformação.

A imprevisibilidade promove a transformação e faz parte da consciência do pesquisador, que busca a geração de informação nova. Assim, são as novas informações que dão sustentabilidade para a cultura não somente continuar a existir, mas identificar o novo.

A experimentação da teoria da semiótica da cultura, articulada com dados empíricos, e a revelação das possibilidades da interdisciplinaridade, e mesmo da transdisciplinaridade, ganha expressão quando se busca compreender a diversidade e seu papel na inovação do conhecimento. Entender as variedades de linguagens na cultura e perceber as dificuldades de comunicação ajuda a inspirar o planejamento de ações estratégicas em bibliotecas, atualizando sua prática e finalidade. Um exemplo disso são os programas educativos, que ensinam os pesquisadores a usar os sistemas de signos das bibliotecas.

É um desafio e também uma questão de sobrevivência para as bibliotecas entender a assimetria e a heterogeneidade semióticas envolvidas na cultura acadêmica. A luta pela sobrevivência de grupos profissionais se revela nos esforços para manter, no centro da semiosfera, registros e normas que identificam a cultura. Entretanto, a sobrevivência não se dá pelo fechamento em si, mas no diálogo com o oposto, que promove a criação, a inovação.

Trabalhando com culturas diferentes, fica mais evidente a percepção da existência das fronteiras entre elas. As áreas da saúde e da ciência da informação se entrelaçam com suas linguagens e modelizações e, ao mesmo tempo, podem se dividir em outras modelizações, como a área de prestação de serviços à população, a área acadêmica. A comunicação e a semiótica contribuem para a decifração dessa característica, a ser considerada e valorizada.

Enfim, no processo de criação do texto científico, compreender como as lacunas são preenchidas pelas informações buscadas em bases de dados, contribui para o diálogo entre o bibliotecário e o pesquisador, apontando pontos de vistas, linguagens e códigos, num contínuo enriquecimento para ambos. 
Promover ambientes inspiradores para a criatividade e preservar a memória são opções para as bibliotecas no sentido de existirem como um grande texto, como uma semiosfera, na complexa práxis do mundo contemporâneo. Nesse sentido, semiótica e ciência se entrecruzam na dialógica da inovação dos processos de conhecimento. 


\section{REFERÊNCIAS}

Abadal E, Codina L. La diversidad cultural em Google y los motores de búsqueda: una aproximación conceptual. Prof Inf. 2008;17(2):191-8.

Almeida Filho N. Transdisciplinaridade e saúde coletiva. Ciênc Saúde Colet. 1997;11(1-2):5-20.

Almeida Filho N. Transdisciplinaridade e o paradigma pós-disciplinar na saúde. Saúde Soc. 2005;14(3):30-50.

Alvarenga AT. A saúde pública como campo de investigação interdisciplinar e a questão metodológica. Saúde Soc. 1994;3(2):23-41.

Alvarenga AT, Philippi Jr A, Sommerman A, Alvarez AMS, Fernandes V. Histórico, fundamentos filosóficos e teórico-metodológicos da interdisciplinaridade. In: Philippi Jr A, Silva Neto AJ, editores. Interdisciplinaridade em ciência, tecnologia \& inovação. Barueri: Manole; 2011. p. 3-68.

Alvarenga AT, Alvarez MAS, Sommerman A, Philippi Jr A. Interdisciplinaridade e transdisciplinaridade nas tramas da complexidade e desafios aos processos investigativos. In: Philippi Jr A, Fernandes V, editores. Práticas da interdisciplinaridade no ensino e pesquisa. Barueri: Manole; 2015. p. 37-89.

Alvarez MCA, Cuenca AMB, Noronha DP, Schor N. Saúde reprodutiva: uma contribuição para avaliação de biblioteca virtual. Cad Saúde Pública [internet]. 2007;23(10):2317-26 [acesso em 5 mar 2014]. Disponível em: http://www.scielosp.org/scielo.php?script=sci_arttext\&pid=S0102$311 \mathrm{X} 2007001000007 \& \operatorname{lng}=\mathrm{en} \& \mathrm{nrm}=$ iso

Alvarez MCA, França Junior I, Cuenca AMB, Bastos FI, Ueno HM, Barros CR, Guimarães MCS. Information literacy: perceptions of Brazilian HIV/aids researchers. Health Inf Libr J [internet]. 2013;31:64-74 [acesso em 10 mar 2014]. Disponível em: http://onlinelibrary.wiley.com/doi/10.1111/hir.12047/pdf

Américo EV. Alguns aspectos da semiótica da cultura de Iuri Lótman [tese]. São Paulo: Faculdade de Filosofia, Letras e Ciências Humanas da USP; 2012.

Anglada L. ¿Son las bibliotecas sostenibles en un mundo de información libre, digital y em red? Prof Inf. 2014;23(6):603-11.

Aran PO. O (im)possível diálogo Bakhtin-Lótman para uma interpretação das culturas. In: Machado IA, organizador. Semiótica da cultura e semiosfera. São Paulo: Annablume: Fapesp; 2007. p. 145-55.

Ayres JRCM, França Junior I, Calazans GJ, Saletti Filho HC. O conceito de vulnerabilidade e as práticas de saúde: novas perspectivas e desafios. In: Czeresnia D, Freitas CM. Promoção da saúde: conceitos, reflexões, tendências. Rio de Janeiro, Fiocruz; 2003. p.117-39.

Bakhtin MM. Estética de la creación verbal. México, DF: Siglo Veintiuno; 1982. 
Barros LA. Curso básico de terminologia. São Paulo: EdUSP; 2004. p. 25-96.

Batalha E. Olhar no futuro. Radis - Comun Sáude [internet]. 2014;(147):22-3 [acesso em 30 dez 2014]. Disponível em: http://www6.ensp.fiocruz.br/radis/sites/default/files/radis_147_web.pdf

Benveniste E. Problemas de linguística geral I. São Paulo: Nacional; 1991. Vista d'olhos sobre o desenvolvimento da linguística.

Bohannon J. Google Scholar wins raver - but can it be trusted? Science. 2014;343(6166):14.

Buchalla CM, Waldman EA, Laurenti R. A mortalidade por doenças infecciosas no início e no final do século XX no Município de São Paulo. Rev Bras Epidemiol [internet]. 2003;6(4):335-44 [acesso em 12 set 2014]. Disponível em: http://www.scielosp.org/scielo.php?script=sci_arttext\&pid=S1415790X2003000400008\&lng=pt. http://dx.doi.org/10.1590/S1415-790X2003000400008

Buckland M. Information as thing. J Am Soc Inf Sci. 1991;42(5):351-60.

Cabré MT. La terminología: representación y comunicación: elementos para una teoría de base comunicativa y otros artículos. Barcelona: IULA: Universitat Pompeu Fabra; 1999.

Cabré MT. La terminología, una disciplina en evolución: pasado, presente y algunos elementos de futuro. Debate Terminol [internet]. 2005;(1) [acesso em 10 ago 2014]. Disponível em: http://seer.ufrgs.br/index.php/riterm/article/view/21286/15349

Cáceres Sánchez M. Iuri Miyáilovich Lótman (1922-1993): una biografia intelectual. In: Lótman YM. La semiosfera. Madrid: Cátedra; 1996. v. 1, p. 249-67.

Carlini-Cotrim B. Potencialidades da técnica qualitativa grupo focal em investigações sobre abuso de substâncias. Rev Saúde Pública. 1996;30(3):285-93.

Carpenter J. Researchers of tomorrow: the research behaviour of generation Y doctoral students. Inf Serv Use. 2012;32:3-17.

Carvalheiro JR, Marques MCC, Mota A. A construção da saúde pública no Brasil no século XX e início do século XXI. In: Rocha AA, Cesar CLG, Ribeiro H, editores. Saúde pública: bases conceituais. 2. ed. São Paulo: Atheneu; 2013. p. 1-18.

Castells M, editor. La sociedade red: uma visión global. Madrid: Alianza; 2009.

Cobus L. Integrating information literacy into the education of public health professionals: roles for librarians and the library. J Med Libr Assoc. 2008;96(1):28-33.

Consolaro A. Adaptação ao mundo, avalanche de informações e a serendipidade na odontologia. Rev Clín Ortod Dental Press. 2008;13(3):23-7. 
Consolaro A. Serendipidade: você usa? J USP. 2014;29(1025):2.

Cuenca AMB. O usuário final da busca informatizada avaliação da capacitação no acesso a bases de dados em biblioteca acadêmica. Ciênc Inf. 1999;28(3):291-9.

Cuenca AMB, Andrade MTD, Noronha DP, Alvarez MCA, Abdalla ERF. Informação em saúde pública e atualização do conhecimento. In: Rocha AA, Cesar CLG, Ribeiro H, editores. Saúde pública: bases conceituais. 2. ed. São Paulo: Atheneu; 2013. p. 369-86.

Cunha IMRF. Do mito à análise documentária. São Paulo: EdUSP; 1990.

Currás E. Ontologias, taxonomias e tesauros em teoria de sistemas e sistemática. Brasília (DF): Thesaurus; 2010. Os tesauros; p. 81-116.

Darnton R. A questão dos livros: passado, presente e futuro. São Paulo: Companhia das Letras; 2010.

Denzin NK, Lincoln YS, editors. Handbook of qualitative research. 2. ed. Thousand Oaks: Sage; 2000.

Eco U. O signo. 4. ed. Lisboa: Presença; 1990. A premissa; p.7-20.

Eco U. Introduction. In: Lótman YM. Universe of the mind: a semiotic theory of culture. Bloomington: Indiana University Press; 2000. p. vii-xiii.

Engels F. A dialética da natureza. Rio de Janeiro: Paz e Terra; 1979. Prólogo de J.B.S. Haldane.

Epstein I. Comunicação na ciência. São Paulo Perspect. 1998;12(4):60-8.

Estrada LMM. Topics maps from a knowledge organization. Knowl Organ. 2011;38(1):43-61.

Faria JH. Prefácio acadêmico. In: Philippi Jr A, Sampaio CAC, Fernandes V. Gestão de natureza pública e sustentabilidade. Barueri: Manole; 2012. p. 15-20.

Ferneda E. Redes neurais e sua aplicação em sistemas de recuperação de informação. Ciênc Inf. 2006;35(1):25-30.

Forattini OP. A língua franca da ciência. Rev Saúde Pública [internet]. 1997;31(1):3-8 [acesso em 19 jul 2011]. Disponível em:

http://www.scielo.br/scielo.php?script=sci_arttext\&pid=S0034-

89101997000100002\&lng=en. doi: 10.1590/S0034-89101997000100002

Foster A, Ford N. Serendipity and information seeking: an empirical study. J Doc. 2003;59(3):321-40.

Freitas ALP, Bolsanello FMC, Viana NRNG. Avaliação da qualidade de serviços de uma biblioteca universitária: um estudo de caso utilizando o modelo Servqual. Ciênc Inf. 2008;37(3):88-102. 
Geertz C. A interpretação das culturas. Rio de Janeiro: Guanabara; 1989. Uma descrição densa: por uma teoria interpretativa da cultura; p. 13-41.

Herzlich S. Saúde e doença no início do século XXI: entre as esferas privada e pública. Physis Rev Saúde Colet. 2004; 14(2):383-94.

Hey T, Tansley S, Tolle K, organizadores. O quarto paradigma: descobertas científicas na era da eScience. São Paulo: Oficina de Textos; 2011.

Hochet Y. Google: tu es si près de moi que je suis tout contre toi. Bull Bibl France [internet]. 2012;(3):1-6 [acesso em 17 mar 2014]. Disponível em:

http://bbf.enssib.fr/consulter/bbf-2012-03-0062-011

Hull D, Pettifer SR, Kell DB. Defrosting the digital library: bibliographic tools for the next generation Web. PLoS Comput Biol. 2008;4(10):e1000204.

Iñiguez L, coordenador. Manual de análise do discurso em ciências sociais. 2. ed. Petrópolis: Vozes; 2005.

Ivánov VV, Lótman YM, Piatigórski AM, Topórov VN, Uspiênski BA. Teses para uma análise semiótica da cultura (uma aplicação aos textos eslavos). In: Machado IA. Escola de semiótica: a experiência de Tártu-Moscou para o estudo da cultura. Cotia: Ateliê;

São Paulo: Fapesp; 2003. p. 99-132.

Kampf C. Acesso aberto ao conhecimento científico tem apoio crescente de cientistas. ComCiência [internet]. 2012;(139):1-5 [acesso em 12 jun 2014]. Disponível em: http://comciencia.scielo.br/pdf/cci/n139/a03n139.pdf

Koch IV. O texto e a construção dos sentidos. 10. ed. São Paulo: Contexto; 2013.

Kondratov A. Sons e sinais na linguagem universal: semiótica, cibernética, linguística, lógica. Brasília (DF): Coordenada; 1972. Os homens, as coisas e as palavras; p. 55-68.

Lana RL. Medicina hipocrática e a semiótica da linguagem na Grécia Antiga. Rev AMRIGS. 2004;48(4):271-4.

Lara MLG. Representação e linguagens documentárias: bases teórico-metodológicas [tese]. São Paulo: Escola de Comunicações e Artes da USP; 1999.

Lara MLG. O processo de construção da informação documentária e o processo de conhecimento. Perspect Ciênc Inf. 2002;7(2):127-39.

Lau J. Guidelines on information literacy for lifelong learning [internet]. The Hague: IFLA; 2006 [acesso em 17 mar 2014]. Disponível em: http://www.ifla.org/files/assets/information-literacy/publications/ifla-guidelines-en.pdf

Le Coadic Y-F. A ciência da informação. Brasília (DF): Briquet de Lemos; 1996.

Lévy P. Cibercultura. São Paulo: Editora 34; 1999. 
Lima VMA. Da classificação do conhecimento científico aos sistemas de recuperação de informação: enunciação de codificação e enunciação de decodificação da informação documentária [tese]. São Paulo: Escola de Comunicações e Artes da USP; 2004.

Lima VMA. Informação documentária: codificação e decodificação. TransInformação. 2007;19(2):119-27.

Lopes E. Fundamentos da linguística contemporânea. São Paulo: Cultrix; 1987. Definição do campo; p. 15-71.

Lótman YM. A estrutura do texto artístico. Lisboa: Estampa; 1978.

Lótman YM. Que nos traz uma abordagem semiótica? In: Lótman YM, Uspenskii B, Ivánov V. Ensaios de semiótica soviética. Lisboa: Horizonte; 1981. p. 27-32.

Lótman YM. El texto en el texto. Semiosis (México). 1990;(24):51-70.

Lótman YM. Semiótica de la cultura en el texto. Madrid: Cátedra; 1996. (La semiosfera; v. 1).

Lótman YM. Semiótica de la cultura, del texto, de la conducta y del espacio. Madrid: Cátedra; 1998. (La semiosfera; v. 2).

Lótman YM. Cultura y explosión: lo previsible y lo imprevisible en los procesos de cambio social. Barcelona: Gedisa; 1999.

Lótman YM. Universe of the mind: a semiotic theory of culture. Bloomington: Indiana University Press; 2000.

Lótman YM, Uspenskii B. Sobre o mecanismo semiótico da cultura. In: Lótman YM, Uspenskii B, Ivanov V. Ensaios de semiótica soviética. Lisboa: Horizonte; 1981. p. 3765 .

Luz MT. Complexidade do campo da saúde coletiva: multidisciplinaridade, interdisciplinaridade, e transdisciplinaridade de saberes e práticas - análise sóciohistórica de uma trajetória paradigmática. Saúde Soc. 2009;18(2):304-11.

Lynch CA, Lippincott JK. Institutional repository deployment in the United States as of early 2005. D-Lib Mag [internet]. 2005;11(9) [acesso em 7 jul 2014]. Disponível em: http://www.dlib.org/dlib/september05/lynch/09lynch.html

McCluskey C. Beyond the library: reflections from a librarian in an academic faculty. Health Inf Libr J. 2010;27(3):249-52.

Machado IA. Escola de semiótica: a experiência de Tártu-Moscou para o estudo da cultura. Cotia: Ateliê; São Paulo: Fapesp; 2003a.

Machado IA, organizador. Semiótica da cultura e semiosfera. São Paulo: Annablume: Fapesp; 2003b. 
Machado IA. Tecidos gráficos da cultura e a expansão dos sistemas de escrita. In: 19. Encontro Anual da COMPÓS [internet]; 2010; Rio de Janeiro. Rio de Janeiro:

COMPÓS; 2010 [acesso em 13 jun 2014]. Disponível em: http://compos.com.pucrio.br/media/gt2_irene_machado.pdf

Machado IA. Língua entre linguagens: a argumentação gráfica na comunicação da ciência [tese de livre-docência]. São Paulo: Escola de Comunicações e Artes da USP; 2011.

Machado IA. Concepção sistêmica do mundo: vieses do círculo intelectual bakhtiniano e da escola semiótica da cultura. Bakhtiniana. 2013a;8(2):136-56.

Machado IA. O método semiótico-estrutural na investigação dos sistemas da cultura. In: Silva AR, Nakagawa RMO, organizadores. Semiótica da comunicação. São Paulo: INTERCOM; 2013b. p. 16-41.

Machado IA, Romanini V. Semiótica da comunicação: da semiose da natureza à cultura. Rev FAMECOS. 2010;17(2):89-97.

Meadows AJ. A comunicação científica. São Paulo: Briquet de Lemos; 1999.

Michaelis Dictionary [CD Rom]. São Paulo: UOL; 2005. Mesh.

Mirim LYL. Garimpando sentidos em bases de dados. In: Spink MJ, organizador. Práticas discursivas e produção de sentidos no cotidiano: aproximações teóricas e metodológicas. 3. ed. São Paulo: Cortez; 2004. p. 153-81.

Monteiro CA. Velhos e novos males da saúde no Brasil: a evolução do país e de suas doenças. 2. ed. aum. São Paulo: Hucitec: Nupens; 2000. (Saúde em Debate).

Morin E. A cabeça bem-feita: repensar a reforma; reformar o pensamento. Rio de Janeiro: Bertrand Brasil; 2004.

Nelson S. Medical Subject Headings [internet]. Bethesda: National Library of Medicine; 2011 [acesso em 10 fev 2014]. Disponível em:

http://www.nlm.nih.gov/pubs/factsheets/mesh.html

Nutefall JE, Ryder PM. The serendipitous research process. J Acad Librariansh. 2010;36(3):228-34.

Odum EP, Barrett GW. Fundamentos da ecologia. São Paulo: Cengage Learning; 2011.

Ortega CD. Relações históricas entre biblioteconomia, documentação e ciência da informação. DataGramaZero [internet]. 2004;5(5) [acesso em 7 jul 2014]. Disponível em: http://www.dgz.org.br/out04/Art_03.htm

Paiva V, Segurado A, Felipe EV, Santos N, Lima TN. Sem direito de amar?: a vontade de ter filhos entre homens (e mulheres) vivendo com o HIV. Rev Psicol USP.

2002;13:105-34. 
Patarra N. Transição demográfica: novas evidências, velhos desafios. Rev Bras Estud Popul. 1994;11(1):27-40.

Paul P. Transdisciplinaridade e antropoformação: sua importância nas pesquisas em saúde. Saúde Soc. 2005;14(3):72-92.

Paul P. Saúde e transdisciplinaridade: a importância da subjetividade nos cuidados médicos. São Paulo: EDUSP; 2013.

Peirce CS. Semiótica. São Paulo: Perspectiva; 1977. O que é o significado? de Lady Welby; p. 157-64.

Posner R. O mecanismo semiótico da cultura. In: Rector M, Neiva E, organizadores. Comunicação na era pós-moderna. Petrópolis: Vozes; 1995. p. 37-49.

Postman N. Tecnopólio: a rendição da cultura à tecnologia. São Paulo: Nobel; 1998. Resenha de: Silva ML, Grimaldi SSL, Fell AFA. Navus Rev Gestão Tecnol. 2013;3(2):202-6.

Prata PR. A transição epidemiológica no Brasil. Cad Saúde Pública [internet]. 1992;8(2):168-75 [acesso em 27 mar 2014]. Disponível em: http://www.scielo.br/pdf/csp/v8n2/v8n2a08.pdf

Queiroz MIP. Relatos orais: do “indizível” ao “dizível”. Ciênc Cult. 1987;39(3):272-86.

Ratzan L. Undertanding information systems: what they do and why we need them. Chicago: American Library Association; 2004. Retrieving information; p. 39-56.

Rey L. Planejar e redigir trabalhos científicos. 2. ed. São Paulo: Edgard Blucher; 1993.

Rifkin J. A era do acesso. São Paulo: Makron Books; 2001.

Rosen G. Uma história da saúde pública. São Paulo: Unesp; 1994.

Rowlands I, Nicholas D, Williams P, Huntington P, Fieldhouse M. The Google generation: the information behaviour of the researcher of the future. Aslib Proc: New Inf Perspect. 2008;60(4):290-310.

Rowley J. A biblioteca eletrônica: segunda edição de informática em bibliotecas. Brasília (DF): Briquet de Lemos; 2002.

Sager J. Prólogo: la terminología, puente entre varios mundos. In: Cabré MT. La terminología: teoría, metodología, aplicaciones. Barcelona: Antártida: Empúries; 1993. p. 11-7.

Sanches KP. A normatização do artigo científico e a estabilidade do gênero. Estud Linguíst. 2009;30(3):165-79.

Santaella L. Semiótica aplicada. São Paulo: Pioneira Thompson Learning; 2002. 
Santaella L. Navegar no ciberespaço. São Paulo: Paulus; 2004.

Saracevic T. Relevance: a review of and a framework for the thinking on the notion of information science. J Am Soc Inf Sci. 1975;26(6):321-43.

Saracevic T. Relevance: a review of the literature and a framework for thinking on the notion in information science - part II: nature and manifestations of relevance. J Am Soc Inf Sci Technol. 2007a;58(13):1915-33.

Saracevic T. Relevance: a review of the literature and a framework for thinking on the notion in information science - part III: behavior and effects of relevance. J Am Soc Inf Sci Technol. 2007b;58(13):2126-44.

Saracevic T. Effects of inconsistent relevance judgments on information retrieval tests results: a historical perspective. Libr Trends. 2008;56(4):763-83.

Saunders L. Identifying core reference competencies from an employers' perspective: implications for instruction. Coll Res Libr [internet]. 2012;73(4):390-404 [acesso em 10 fev 2014]. Disponível em: http://crl.acrl.org//content173/4.toc

Schraiber LB. Pesquisa qualitativa em saúde: reflexões metodológicas do relato oral e produção de narrativas em estudo sobre a profissão médica. Rev Saúde Pública. 1995;29(1):1-10.

Sebeok TA. Comunicação. In: Rector M, Neiva E, organizadores. Comunicação na era pós-moderna. Petrópolis: Vozes; 1997. p. 50-64.

Secretaria da Saúde do Estado de São Paulo. Vigilância em saúde: 20 anos de SUS-SP. São Paulo; 2008. Programa Estadual DST/aids faz 25 anos: uma história que mudou a cara da aids no Brasil e no mundo; p. 125-42.

Shenton AK. Information literacy and scholarly investigation: a British perspective. IFLA J. 2009;35:226-31.

Snow CP. As duas culturas e uma segunda leitura: uma versão ampliada das duas culturas e a revolução científica. São Paulo: EdUSP; 1995.

Sokal A, Bricmont J. Imposturas intelectuais. 2. ed. Rio de Janeiro: Record; 2001.

Sommerman A. Interdisciplinaridade e transdisciplinaridade como formas de conhecimento para a articulação de saberes no contexto da ciência e do conhecimento em geral: contribuição para os campos da Educação, da Saúde e do Meio Ambiente [tese]. Salvador: Universidade Federal da Bahia; 2012.

Tálamo MFGM. Linguagem documentária. São Paulo: Associação Paulista de Bibliotecários; 1997. (Ensaios APB; 45).

Tálamo MFGM. A pesquisa: recepção da informação e produção do conhecimento. DataGramaZero. 2004;5(2):1-16. 
Tálamo MFGM, Lara MLG, Kobashi NY. Contribuição da terminologia para a elaboração de tesauros. Ciênc Inf. 1992; 21(3):197-200.

Torop P. A Escola de Tártu como Escola. In: Machado IA. Escola de semiótica: a experiência de Tártu-Moscou para o estudo da cultura. Cotia: Ateliê; São Paulo: Fapesp; 2003. p. 69-95.

Torop P. Semiosfera como objeto de pesquisa na semiótica da cultura. In: Machado IA, organizador. Semiótica da cultura e semiosfera. São Paulo: Annablume: Fapesp; 2007. p. 45-56.

Van Noorden R. Publishers withdraw more than 120 gibberish papers. Nature News [internet]. 25 Feb 2014 [acesso em 29 jun 2014]. Disponível em: http://www.nature.com/news/publishers-withdraw-more-than-120-gibberish-papers1.14763

Velho APM. Jornalismo hipermídia: desenhando a notícia científica na web [tese]. São Paulo: Pontifícia Universidade Católica; 2007.

Vergueiro WCS. Desenvolvimento de coleções: uma nova visão para o planejamento de recursos informacionais. Ciênc Inf. 1993;22(1):1-9.

Vogel MJM. A noção de estrutura linguística e do processo de estruturação e sua influência no conceito e na elaboração de linguagens documentárias [dissertação]. São Paulo: Escola de Comunicações e Artes da USP; 2007.

Volpato G. Bases teóricas para redação científica. São Paulo: Cultura Acadêmica; 2007.

Volpato G. Administração da vida científica. São Paulo: Cultura Acadêmica; 2009. 
ANEXO: Roteiro da entrevista

Roteiro - Entrevista Individual da Pesquisa: Transformações na comunicação científica: identificando necessidades e experimentando tecnologias com grupos de pesquisadores em HIV/AIDS.

\section{Aquecimento:}

Apresente-se ao entrevistado, fazer o possível para deixar o pesquisador confortável.

\section{Processo de Consentimento:}

Falar da pesquisa (nome, objetivos e instituição responsável), dos direitos à recusa, interrupção da participação em qualquer momento, do sigilo das informações prestadas e de que, em caso de recusa, não haverá NENHUM problema.

Após o entrevistado ler o TCLE, solicitar que assine as duas vias e entregar uma cópia para o entrevistado. (NÃO PRECISA LER JUNTO E NEM GRAVAR ESTA PARTE)

\section{Início da entrevista:}

Falar do gravador

Primeiro será mais livre e a gente vai conversar sobre você <nome do pesquisador> livremente, do jeito que você quiser ir falando... da forma como você quiser ir contando sobre sua vida como pesquisador, como faz para estudar e fazer as suas pesquisas.

Depois, vamos conversar sobre questões mais específicas, que vamos perguntar para todos os entrevistados.

\section{I - INTRODUÇÃO}

Nós tivemos o cuidado de levantar as informações profissionais em seu currículo Lattes e gostaríamos de confirmar algumas. Pra começar e eu poder anotar aqui:

Há quanto tempo você trabalha com pesquisa?

Há quanto tempo você pesquisa sobre AIDS?

Há quanto tempo você está neste grupo de pesquisa? NEPAIDS (SÃO

PAULO) E LIS (RIO DE JANEIRO)

Há quanto tempo você está nesta instituição?

Além de pesquisa, que outras atividades você tem?

Obs: Evitar falar. Estimular a fala livre, com expressões convidativas Hum, hum... Ahhhh, Que mais? É isso? (explorar o que pareça importante para o entrevistado, repetindo frases do próprio) 


\section{II - DISCURSO LIVRE}

Gostaríamos que você nos contasse um pouco mais sobre a sua trajetória como pesquisador(a) em aids.

\section{III - Agora vamos começar as perguntas que vamos fazer para todos.}

Qual pesquisa sobre aids que você está se dedicando no momento?

Obs: Se não tiver pesquisa em andamento sobre aids, perguntar sobre a anterior

Quando foi a última vez que você necessitou de informações científicas?

Como você fez esta busca bibliográfica?

Obs: Explorar se isso é o que faz normalmente; as dificuldades que encontrou; bases de dados relativas a este projeto utilizadas; porque fez deste modo; e se ele ou ela tem conhecimento da existência de outro modo; e bases de dados não citadas pelo entrevistado.

Você disse que algumas o atrapalhavam? Como se deu esta dificuldade?

Nas buscas e uso de bibliografia, quais foram as facilidades?

Qual o último artigo que você leu? Sobre qual temática? Como obteve?

Você recebe formas automatizadas de informações sobre publicações, como alertas, listas de discussão, RSS?

O que você gostaria de ter à disposição para facilitar a busca da informação?

\section{IV - CENAS}

Como você imagina que teria sido essa busca há uns 10 anos? Descreva a cena.

Obs: Explorar como fazia a busca bibliográfica: utilizava computador, bibliotecas, bases de dados...

E como você imagina que será daqui a 5 anos... Descreva a cena.

Obs: Explorar como acha que será a busca: local, tecnologia, bases de dados...

O que você gostaria que tivesse disponível para facilitar seu trabalho de busca?

Obs: Se o entrevistado(a) não falar nada sobre o uso de bibliotecas, explorar o assunto.

Finalizando, estamos pensando em reunir todos os pesquisadores que deram entrevista para uma discussão em grupo sobre o que conversamos agora... Você poderia participar? Obrigada(o)! 


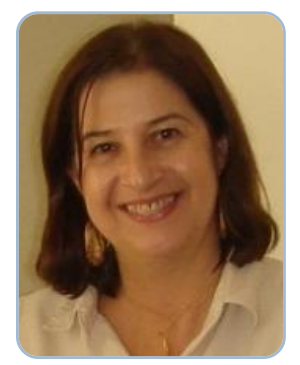

\section{Maria do Carmo Avamilano Alvarez}

Endereço para acessar este CV: http://lattes.cnpq.br/5582514210581920

Última atualização do currículo em 22/04/2014

Mestre em Saúde Pública pela Faculdade de Saúde Pública da Universidade de São Paulo (FSP/USP) em 2005. Cursando doutorado na mesma instituição. Bibliotecária Chefe da Divisão de Biblioteca da FSP/USP. Experiência na área de Ciência da Informação, atuando principalmente nas seguintes áreas: gestão, bibliotecas virtuais, acesso à informação e capacitação do usuário. (Texto informado pelo autor)

\section{Identificação}

\section{Nome}

Maria do Carmo Avamilano Alvarez

Nome em citações bibliográficas

ALVAREZ, M. C. A.;ALVAREZ, MARIA DO CARMO AVAMILANO

\section{Endereço}

Endereço Profissional

Universidade de São Paulo, Faculdade de Saúde Pública.

Av Dr. Arnaldo, 715

Cerqueira Cesar

01246-904 - Sao Paulo, SP - Brasil

Telefone: (011) 30617760

Fax: (011) 30641462

URL da Homepage: www.bibcir.fsp.usp.br

\section{Formação acadêmica/titulação}

2001 - 2005

$1997-1997$

$1982-1985$

$1978-1980$
Mestrado em Saúde Pública (Conceito CAPES 5).

Universidade de São Paulo, USP, Brasil.

Título: A Biblioteca Virtual de Saúde Reprodutiva: dando voz ao usuário,Ano de Obtenção: 2005.

Orientador: (9) Profa. Dra. Néia Schor.

Palavras-chave: Grupo focal; Bibliotecas virtuais; Internet; tecnologias. Grande área: Ciências da Saúde / Área: Saúde Coletiva / Subárea: Saúde Pública / Especialidade: Saúde reprodutiva.

Setores de atividade: Educação Superior.

Especialização em Especialização em Saúde Pública - Epidemiologia. (Carga Horária: 360h).

Faculdade de Saúde Pública da USP.

Título: TCM - Piraju.

Graduação em Biblioteconomia.

Escola de Comunicações e Artes da Universidade de São Paulo.

Ensino Médio ( $2^{\circ} \mathrm{grau}$ ).

EEPSG Professor Américo Brasiliense. 


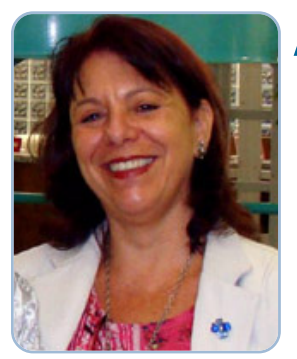

\section{Angela Maria Belloni Cuenca}

Endereço para acessar este CV: http://lattes.cnpq.br/9289612477584785

Última atualização do currículo em 21/11/2014

Docente da Faculdade de Saúde Pública da USP pelo Departamento de Saúde MaternoInfantil,orientadora na pós-graduação, em nível de mestrado e doutorado, na área de concentração Sáude, Ciclos de Vida e Sociedade, e responsável pela disciplina Metodologia da Divulgação do Artigo Científico. Ainda Programa de Pós-Graduação em Saúde Pública integra a coordenação da cooperação acadêmica entre FSP/USP e o Programa de Doutorado em Saúde Pública da Universidade Federal do Acre (Edital CAPES 2011). Na graduação ministra disciplinas de Acesso e Uso da Informação Bibliográfica para o Curso de Nutrição e o Bacharelado em Saúde Pública. Coordena o grupo de pesquisa em Comunicação Científica em Saúde Pública, desenvolvendo pesquisas que abrangem análise de revistas científicas, bibliometria, acesso e uso da informação científica, comunidades acadêmicas, bibliotecas virtuais e acadêmicas, competência em informação. Foi Diretora da Biblioteca/Centro de Informação e Referência da FSP/USP de 2003 a 2013. Graduada em Biblioteconomia pela Fundação Escola de Sociologia e Política de São Paulo (1977), possui Mestrado (1998) e Doutorado (2004) em Saúde Pública pela Faculdade de Saúde Publica da Universidade de São Paulo. (Texto informado pelo autor)

\section{Identificação}

\begin{tabular}{ll}
\hline Nome & Angela Maria Belloni Cuenca \\
Nome em citações bibliográficas & CUENCA, A. M. B.;CUENCA, ANGELA MARIA BELLONI
\end{tabular}

\section{Endereço}

\section{Endereço Profissional}

\author{
Universidade de São Paulo, Faculdade de Saúde Pública. \\ Avenida Dr Arnaldo, 715 \\ Cerqueira Cesar \\ 01246904 - São Paulo, SP - Brasil \\ Telefone: (11) 30617968 \\ URL da Homepage: http://www.fsp.usp.br
}

